Please cite this article as:

Urbinati, A., Chiaroni, D., Chiesa, V., \& Frattini, F. (2019).

The Role of Business Model Design in the Diffusion of Innovations: An Analysis of a Sample of Unicorn-Tech Companies.

International Journal of Innovation and Technology Management, 16(01), 1950011.

(DOI: https://doi.org/10.1142/S0219877019500111) 


\title{
THE ROLE OF BUSINESS MODEL DESIGN IN THE DIFFUSION OF INNOVATIONS: AN ANALYSIS OF A SAMPLE OF UNICORN-TECH COMPANIES
}

\author{
Andrea Urbinati ${ }^{1,2 *}$, Davide Chiaroni ${ }^{1}$, Vittorio Chiesa ${ }^{1}$, \\ and Federico Frattini ${ }^{1}$ \\ ${ }^{1}$ Politecnico Di Milano, Department of Management Economics and Industrial Engineering \\ Via R. Lambruschini, 4/b, Milan 20156, Italy \\ ${ }^{2}$ LIUC - Università Cattaneo, School of Industrial Engineering \\ Corso Matteotti, 22 - 21053 Castellanza (VA), Italy \\ * Corresponding author: andrea.urbinati@polimi.it \\ davide.chiaroni@polimi.it \\ vittorio.chiesa@polimi.it \\ federico.frattini@polimi.it
}

\begin{abstract}
Innovation scholars have long studied how and why new products and services diffuse into the market following trajectories such as the S-curve and in accordance with epidemic, social, and information cascades models. However, we see today many new products and services, especially those enabled by digital technologies, which do not seem to fit to the above-mentioned trajectories and models due to the incredibly high speed and virulence at which they diffuse. Moreover, the diffusion of these innovations does not seem to depend, contrary to what the previous patterns of innovation diffusion argue, on their technological characteristics or on demand-side factors, such as the word-of-mouth effect or the feedback they receive from their early adopters. Rather, their diffusion seems to be affected by the characteristics of the business model adopted by the companies that have created and commercialized them into the market. Accordingly, our study analyzes through the historical research methodology the business model of a sample of 50 Unicorn techcompanies, which have experienced incredibly fast diffusion rates and business growth and are disrupting entire industries. The outcome of our study is a framework that maps two business model configurations that explain the role of different business model design and innovation choices in the diffusion of new products and services enabled by digital technologies.
\end{abstract}

Keywords: business model, business model design, business model innovation, innovation diffusion, digital technologies, Unicorns.

\section{INTRODUCTION}

Innovation scholars have long studied how and why new products and services diffuse into the market following determined trajectories, such as the S-curve, and in accordance with epidemic, social, and information cascades models (Tarde, 1903; Ryan \& Gross, 1943; Rogers, 2003; Geroski, 2000; Shilling, 2005).

However, we see today many new products and services, especially those enabled by digital technologies, that do not seem to fit to the above-mentioned trajectories and models due to the incredibly high speed at which they diffuse into the market.

Recent studies in the field of business model design (Casadesus-Masanell \& Zhu, 2013; Markides, 2013; Schneider \& Spieth, 2013; Spieth, et al., 2014) and innovation (Trapp, et al., 2018; Foss \& Saebi, 2017) are trying to understand and describe how companies shape their business model to affect the extent to which their products or services develop and diffuse into the market. These 
contributions suggest that we need more theoretical and empirical research on the reasons that explain the diffusion of innovations into the market because of business model design and innovation choices of companies that launch them into the market.

Starting from these premises, our paper analyzes through the historical research method the business model of a sample of the (so-called) Unicorn tech-companies, whose products and services have experienced incredibly fast diffusion rates and business growth and are disrupting entire industries. The outcome of our study is a framework that maps two different clusters of business model that explain the role of different business model design and innovation choices in the diffusion of new products and services enabled by digital technologies.

For the sake of simplicity, in the remainder of this paper we will refer to "Unicorn tech-companies" or "Unicorns" with the same meaning, i.e. companies that have launched and commercialized digitally enabled products and services and have experienced incredibly fast diffusion rates and business growth and are disrupting entire industries.

The paper is organized as follows. The next section (Section 2) gives a brief overview of the existing literature on the traditional patterns of innovation diffusion (Section 2.1), on the research streams of business model design and innovation (Section 2.2), to finally highlight the research question (Section 2.3). Afterwards, we summarize in Section 3 the rationale of the methodology, highlighting the sample of companies used for the empirical analysis (Section 3.1), the historical analysis methodology (Section 3.2) and the procedure for conducting the empirical analysis (Section 3.3). Then, in Section 4, we summarize and discuss our findings, pointing out theoretical and practical implications ensuing from our study. Finally, in Section 5 point out some avenues for future research.

\section{LiteratURE REVIEW}

\subsection{TRADitional PATtERNS OF INNOVATION DifFUSION}

Since years, innovation scholars have paid special attention to the dynamics and trajectories underlying the diffusion of new products and services into the market (Schumpeter, 1961; Rosenberg, 1976; Davis, 1989). The main streams of research on this topic have used epidemic, social, and information cascades models to explain these dynamics and trajectories of innovation diffusion (Tarde, 1903; Ryan \& Gross, 1943; Rogers, 2003; Moore; 1991; Geroski, 2000; Shilling, 1998, 2005).

In this section, we provide an overview of the existing literature on the above-mentioned trajectories and models of innovation diffusion with the aim to highlight the main streams of research and existing gaps in this field of study.

\section{Epidemic models}

Several studies have described the patterns through which technological change impacts the markets with the well-known S-curve trajectories, which explain how a new product or service evolves and spreads within a market along three main phases, i.e. innovation, grow and maturity (Tarde, 1903). According to the S-curve trajectory, once the innovation occurs into the market, it generally spreads from the innovator to an initial group of people, also known as early adopters. These people know better than other users the characteristics of the new product or service and allow its diffusion into the market. Mostly, early adopters have the power to increase the rate of diffusion of the innovation from a minority to most other users thanks to their word-of-mouth effect (Moore, 1991). However, in the early stages of the product's lifecycle, the growth of the innovation is relatively slow as well as its establishment into the market. Afterwards, when the influence of early adopters takes hold, other users begin to demand the product or service and it grows more rapidly. Therefore, new incremental innovations or changes on that product or service allow its exponential take off until the end of its lifecycle, when it enters in the phase of maturity or decline. The main explanation of the Scurve trajectory are the epidemic models of information diffusion (Geroski, 2000), which consider "legitimation" and "competition" as the primary drivers influencing the diffusion of innovations into 
the market following the S-curve trajectory. In particular, according to Geroski (2000, p. 616), "legitimation gradually erodes barriers facing a new type organization, raising its birth rate and increasing its survival prospects. This drives a gradual increase in the net birth rate of the new organization. However, as the population of the new type of organization increases, a competition for resources sets in. This crowding is likely to have the effect of lowering birth rates and raising death rates, and, consequently, it lowers the rate of organizational expansion. This rise and fall in the net birth rate is, of course, just what underlies the S-curve". According to these streams of research, innovations spread among users following the S-curve trajectory, and this mostly depends upon intrinsic characteristics of the market, such as the word-of-mouth effect enabled by the early adopters. This legitimates the diffusion of the innovations among the other users and allows increasing the competition between firms who use the new product or service to serve the market.

\section{Social models}

Other scholars have conceptualized the S-curve trajectory as a social process, in which five actors play a key role in fostering the diffusion of new products or services, i.e. innovators, early adopters, early majority, late majority and laggards (Ryan \& Gross, 1943). Each of these actors has distinctive and peculiar characteristics and the diffusion of new products or services depends on the word-ofmouth (and persuasion) effect triggered by each category of these adopters. According to the study of Ryan \& Gross (1943), the technological characteristics of new products or services do not contribute to their spread into the market; conversely, they induct a greater resistance for their adoption. In a similar way, Rogers (2003) has explained diffusion of innovations as a communication process across the same actors. However, he has identified some specific technological characteristics of innovations that are perceived as useful for understanding their different rates of adoption, which are (i) relative advantage, (ii) compatibility, (iii) complexity, (iv) trialability, and (v) observability. In this case, what allows the spread of new products or services into the market is not the persuasion, but the reinvention process that makes the innovation easier, simpler, quicker and more advantageous. Whether Ryan \& Gross (1943) sustain that innovations spread thanks to intrinsic characteristics of the market, i.e. the feedback circulating on the innovations among each actor, Rogers (2003) sustains that the technological characteristics of new products or services mostly contribute to their spread into the market.

\section{Information cascades models}

Information cascades are defined as situations in which “...it is optimal for an individual, having observed the actions of those ahead of him, to follow the behaviour of the preceding individual without regard to his own information" (Geroski, 2000, p. 619). In particular, in the diffusion process of new products and services driven by information cascades, three subsequent phases can be observed and relate to (i) the choice of one between two different variants of a new product or service that simultaneously appear into the markets, (ii) the lock-in effect enabled by network externalities, if present, and (iii) the bandwagon effect induced by the willingness to imitate the specific variant of the new product or service (Bannerjee, 1992; De Vany \& Walls, 1996; Bikhchandani, et al., 1992; Bikhchandani, et al., 1998).

Accordingly, all the above-mentioned theories and models assume that new products or services spread into the market following identifiable phases of diffusion and across specific actors. In addition, the patterns of diffusion depend either on the technological characteristics of the innovations, which improve over time thanks to new incremental innovations or changes on the same technological attributes, or on social dynamics that happen on the demand-side of the market, i.e. lock-in and bandwagon effects, network externalities, word-of-mouth effects or the feedback triggered by the early adopters and circulating among each actor.

Notwithstanding, new products and services, especially those enabled by digital technologies, do not seem to follow the patterns of diffusion explained by the above-mentioned trajectories and models, such as the S-curve. On the contrary, several examples of the most recent innovations have spread 
into the market in record times, with a significative growth in the early stages of the diffusion process and without the need of a word-of-mouth triggered by the early adopters. Some scholars and practitioners have called them "big bang disruptions" (Downes \& Nunes, 2013), aiming to underline the intensive and virulent way through which they have spread into the market, and conceptualized the related pattern of diffusion as "shark-fin" (Figure 1A of the Appendix shows the "Traditional business S-curve and the "shark-fin" model").

Therefore, although it is very rich in terms of theoretical and managerial implications, traditional literature on innovation diffusion does not properly explain:

i. If there are other mechanisms, beyond the technological characteristics of innovations or the social dynamics that happen on the demand-side of the market, which can explain how new products and services enabled by digital technologies diffuse into the market.

We argue in this paper that the diffusion process of these new products and services can be influenced by the business model design and innovation choices of the companies that have launched and commercialized them into the market. Accordingly, we build on recent observations in the fields of business model design (Casadesus-Masanell \& Zhu, 2013; Markides, 2013; Schneider \& Spieth, 2013; Spieth, et al., 2014) and innovation (Trapp, et al., 2018; Foss \& Saebi, 2017), which call for a more theoretical and empirical research on the reasons that explain the diffusion of innovations into the market because of the business model design and innovation choices of companies.

\subsection{BUSINESS MODEL DESIGN AND INNOVATION}

To explain the business model design and innovation choices of our Unicorns, we initially reviewed the research streams of business model design and innovation, and then introduce the dimensions of the Business Model Canvas framework (Osterwalder, 2004; Osterwalder \& Pigneur, 2013), i.e. the Value Network, the Customer Value Proposition \& Interface, and the Economic Model, which we will use for the empirical analysis.

A business model design represents a set of strategic decisions that defines how companies create, transfer, and capture value according to their internal activities and relationships with stakeholders, among which suppliers and customers (Afuah \& Tucci, 2001; Osterwalder, et al., 2005; Zott, et al., 2011; Osterwalder \& Pigneur, 2013). For several years, literature on strategic management has studied the role of the business model design to shape the strategy of companies. Indeed, the design of the business model represents for organizations a driver of competitiveness, defining how to position into the market against competitors. Accordingly, managers consider the design of the business model as a strategic priority for companies in which they operate (Chesbrough, 2007, 2010; Ireland, et al., 2001). In the current context of digital transformation, companies are also called for a continuous innovation of their business model intended as the "architecture of value creation, delivery and capture mechanism" of a firm (Teece, 2010, p. 191). And digital technologies are more and more considered a key antecedent of business model innovation (e.g. Pateli \& Giaglis, 2005), defined as "designed, novel, non-trivial changes to the key elements of a firm's business model and/or the architecture linking these elements" Foss \& Saebi (2017, p. 201).

However, to best of our knowledge, the research streams of business model design and innovation lack specific attention to the role that different business model configurations can play in the diffusion of new products and services enabled by digital technologies. This is an important point to address if we want to respond to the research question highlighted above and advance existing research at the interface between the business model concept and diffusion of digital innovations. Accordingly, our aim is to study the diffusion of new products and services digitally enabled under the lens of business model design and innovation fields, to provide evidence that different business model design and innovation choices with which these products and service are created and commercialized affect their speed and patterns of diffusion. 
To do so, we use the Business Model Canvas framework (Osterwalder, 2004), as that "visual and design-informed tool to enhance strategic thinking about business model innovation" (Spieth, et al., 2014 , p. 243), and one of the main representations of the business model, from a strategic design perspective (Spieth, et al., 2014; Massa, et al., 2016). In addition, this framework represents one of the most well-known frameworks used to represent a business model and already used for empirical studies (Urbinati, et al., 2017; Fritscher \& Pigneur, 2009; Meertens, et al., 2012; Muhtaroglu, et al., 2013; Zolnowski, et al., 2014; Vargas, et al., 2015; Joyce \& Paquin, 2016). The Business Model Canvas is a reference framework with nine building blocks through which organizations can represent their business. The customer segment block describes the group of customers with different characteristics and needs that organizations aim to reach and serve. The value proposition block represents the bundle of products and services that satisfy customer segments' needs. The distribution channels and customer relationship blocks aim at connecting the customer segments and value proposition blocks. The former describes the channels through which organizations communicate with customers and through which offer their value proposition, the latter highlights the types of relationships that organizations establish with each customer segment. These four blocks constitute the dimension of the Customer Value Proposition \& Interface of the organizations. The key resources block describes the set of assets on which the business model of organizations is built. The key activity block includes the most important activities performed by the organizations to implement their business model. The key partners (or partner network) block shows the network of suppliers and partners the organizations work with. These three blocks constitute the dimension of the Value Network of the organization. Finally, the revenue streams and the cost structure blocks constitute the dimension of the Economic Model of the organization. The former describes the streams through which the organizations earn revenues from their customers for value creation and customer-facing activities, the latter describes the costs the organizations incur to run their business.

\subsection{RESEARCH QUESTION}

Starting from the premises above, the aim of this paper is to close the gap in existing literature (depicted in Figure 1), and answering the following research question: "How do different business model design and innovation choices of companies that launch and commercialize digitally enabled products and services affect their speed and pattern of diffusion?"

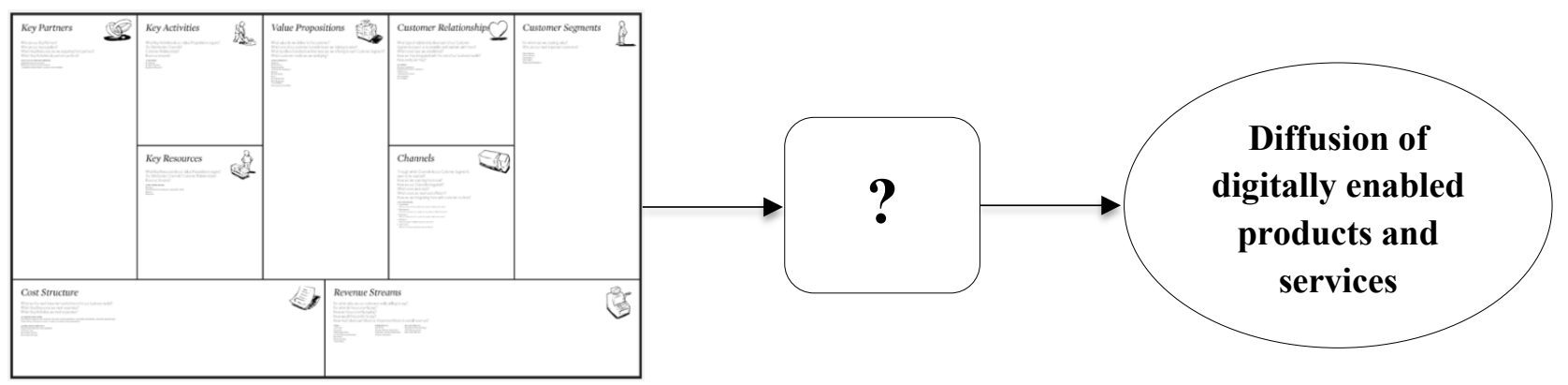

Figure 1: Gap in the existing research.

\section{METHODOLOGY AND EMPIRICAL ANALYSIS}

\subsection{SAMPLE OF UNICORN-TECH COMPANIES}

To answer to the research question highlighted in the previous section, we started to analyze a sample of innovations launched by those companies known as the Unicorn tech-companies (or "The Billion Dollar Start-up Club", according to a Wall Street Journal article published in February 2015). Unicorns are venture-backed private companies valued at \$ 1 billion or more by venture capital firms. The Wall Street Journal provides an updated list of these organizations in the following web site: http://graphics.wsj.com/billion-dollar-club/. Here are highlighted the latest valuation (billions of \$), 
the total equity funding (billions of \$), and the last valuation (month/year) of each Unicorn. For further reference, a recent report published in Harvard Business Review (Ramadan, et al., 2015) highlights the dynamics lying behind the market evaluation of the Unicorns. Furthermore, De Massis, et al., (2016) have identified four main characteristics that the Unicorns have in common explaining the great success of these type of companies, i.e. small in size, led by serial entrepreneurs, financed by VC firms, and narrowly focused. Accordingly, these studies suggest new interpretations of the reasons that can explain diffusion of these innovations into the market.

Therefore, the choice to study these innovations arises from the incredible success they have built in the market where they appeared, as well as the lightning and extremely fast diffusion they have experienced in the last years. These Unicorns have created incredibly fast diffusion processes and have built very successful businesses. The Unicorns offer their products or services in a wide range of markets, such as energy, automotive, infrastructure, as well as the mobile phone market or the transportation one. Examples of these innovations are Uber or BlaBlaCar (two car-sharing services), as well as Xiaomi (the Chinese firm producing and commercializing tablet, smartphones and other electronic devices worldwide), as well as Airbnb (the Californian room-sharing service). Anyway, the way through which these innovations have spread into the market does not seem to fit to the trajectories and models of innovation diffusion analyzed in Section 2.1. Rather, different characteristics of the business model adopted by the companies that have created and commercialized them into the market seem to affect largely their diffusion. Accordingly, we have analyzed the business model of a sample of Unicorns considering the building blocks of the Business Model Canvas framework described above (Osterwalder, 2004; Osterwalder and Pigneur, 2013). Therefore, the Value Network, the Customer Value Proposition \& Interface, and the Economic Model were analyzed for each sampled innovation with the aim to identify how different business model design and innovation choices were able to determine incredibly fast diffusions of these new products and services.

Table 1 provides some preliminary key data on our sample of Unicorn-tech companies. Data on the latest valuation have been collected on the date of April 7, 2016. We wrote n.a., i.e. not available, when data and information were not found or not corroborated by multiple sources.

Table 1: Preliminary data on our sample of Unicorn-tech companies.

\begin{tabular}{|c|c|c|c|c|c|c|c|}
\hline Unicorns & $\begin{array}{c}\text { Date of } \\
\text { foundation }\end{array}$ & Service offered & Industry & Headquarter & $\begin{array}{c}\text { Latest } \\
\text { valuation } \\
\text { (bn \$) }\end{array}$ & $\begin{array}{l}\text { Number of } \\
\text { employees }\end{array}$ & $\begin{array}{l}\text { Number of } \\
\text { users }\end{array}$ \\
\hline Uber & March 1, 2009 & $\begin{array}{l}\text { Transportation platform that } \\
\text { links passengers and drivers } \\
\text { through a mobile app }\end{array}$ & Transportation & San Francisco, US & $\$ 51.0$ bn & $\begin{array}{c}160.000+ \\
\text { employees }\end{array}$ & $\begin{array}{c}\text { July } 2014 \\
\text { registered } 8 \\
\text { million users. } \\
\text { January } 2015 \\
\text { registered } \\
1.600 .000 \text { drivers. } \\
\text { In March } 2015, \\
\text { Uber reached } 290 \\
\text { cities in } 56 \\
\text { countries }\end{array}$ \\
\hline Xiaomi & April 4, 2010 & $\begin{array}{c}\text { Private-owned company that } \\
\text { develops and sells mobile } \\
\text { phone and consumer } \\
\text { electronics goods }\end{array}$ & $\begin{array}{l}\text { Consumer } \\
\text { electronics }\end{array}$ & Beijing, CN & $\$ 46.0$ bn & $\begin{array}{c}3.000 \\
\text { employees }\end{array}$ & n.a. \\
\hline Airbnb & August, 2008 & $\begin{array}{l}\text { Online community } \\
\text { marketplace for people to } \\
\text { list, discover and book } \\
\text { accommodations around the } \\
\text { world }\end{array}$ & Hotels, Travels & San Francisco, US & $\$ 25.5$ bn & $\begin{array}{c}1.600 \\
\text { employees }\end{array}$ & $\begin{array}{l}50 \text { million users. } \\
\text { The majority is } \\
\text { female }(54 \%) \text {. It is } \\
\text { present in } 34.000+ \\
\text { cities across } 190+ \\
\text { countries }\end{array}$ \\
\hline Palantir & 2004 & $\begin{array}{l}\text { Suite of software applications } \\
\text { for integrating, visualizing } \\
\text { and analyzing information }\end{array}$ & Data analytics & Palo Alto, US & $\$ 20.0$ bn & $\begin{array}{c}1.500 \\
\text { employees }\end{array}$ & $\begin{array}{l}\text { At the beginning } \\
\text { the only customer } \\
\text { was the United } \\
\text { States Intelligence } \\
\text { Community, but } \\
\text { then the service } \\
\text { expanded to local } \\
\text { governments and } \\
\text { private companies }\end{array}$ \\
\hline
\end{tabular}




\begin{tabular}{|c|c|c|c|c|c|c|c|}
\hline $\begin{array}{l}\text { Meituan- } \\
\text { Dianping }\end{array}$ & March 4, 2010 & $\begin{array}{c}\text { Group-buying website } \\
\text { specializing in localized } \\
\text { consumer services, offering a } \\
\text { selection of local restaurants, } \\
\text { bars and more }\end{array}$ & $\begin{array}{l}\text { Group Buying, } \\
\text { E-commerce, } \\
\text { Internet, Online } \\
\text { shopping, } \\
\text { Discounts }\end{array}$ & Beijing, CN & $\$ 18.3$ bn & $\begin{array}{c}5.000 \\
\text { employees } \\
\text { (December, } \\
2015 \text { ) }\end{array}$ & $\begin{array}{l}200 \text { million active } \\
\text { users. The } \\
\text { company operates } \\
\text { in more than } \\
1.000 \text { Chinese } \\
\text { cities }\end{array}$ \\
\hline Snapchat & May 1, 2011 & $\begin{array}{l}\text { Photo messaging app that } \\
\text { allows users to take photos, } \\
\text { and record videos, add text } \\
\text { and drawings and send them } \\
\text { to recipients }\end{array}$ & Social Media & $\begin{array}{l}\text { Pacific Palisades, } \\
\text { US }\end{array}$ & $\$ 16.0 \mathrm{~B}$ & 330 employees & $\begin{array}{c}200+\text { million } \\
\text { active users } \\
\text { worldwide with } \\
400+\text { million } \\
\text { snaps sent every } \\
\text { day. Its core users } \\
\text { are between } 13 \\
\text { and } 24 \text { years old. } \\
70 \% \text { of them are } \\
\text { female }\end{array}$ \\
\hline WeWork & $\begin{array}{l}\text { February } 15 \\
\quad 2010\end{array}$ & $\begin{array}{l}\text { Platform that provides space, } \\
\text { community and services for } \\
\text { people who need to create } \\
\text { their life's work }\end{array}$ & $\begin{array}{l}\text { Social Media, } \\
\text { Co-working, } \\
\text { Real Estate }\end{array}$ & New York, US & $\$ 16.0 \mathrm{bn}$ & 800 employees & $\begin{array}{c}\text { WeWork has } \\
\text { experienced } \\
\text { growth with more } \\
\text { than } 41.000 \\
\text { members in } 54 \\
\text { different locations } \\
\end{array}$ \\
\hline Didi Kuaidi & September, 2012 & $\begin{array}{l}\text { Combination of two largest } \\
\text { taxi hailing companies in } \\
\text { China } \\
\end{array}$ & Transportation & Beijing, $\mathrm{CN}$ & $\$ 16.0 \mathrm{bn}$ & $\begin{array}{l}4.000 \\
\text { employees }\end{array}$ & $\begin{array}{l}160 \text { million of } \\
\text { users }\end{array}$ \\
\hline Flipkart & $\begin{array}{l}\text { September } 1 \text {, } \\
\quad 2007\end{array}$ & $\begin{array}{l}\text { Online shopping destination } \\
\text { for electronics, books, music } \\
\text { and movies. It offers over } 20 \\
\text { million products across } 70+ \\
\text { categories } \\
\end{array}$ & $\begin{array}{l}\text { E- commerce, } \\
\text { Online shopping }\end{array}$ & Bangalore, IN & $\$ 15.0 \mathrm{bn}$ & $\begin{array}{l}33.000 \\
\text { employees }\end{array}$ & $\begin{array}{l}22 \text { million } \\
\text { registered users }\end{array}$ \\
\hline SpaceX & June, 2002 & $\begin{array}{l}\text { Transportation company that } \\
\text { designs, manufactures and } \\
\text { launches advanced rockets, } \\
\text { spacecraft and satellites }\end{array}$ & $\begin{array}{l}\text { Aerospace and } \\
\text { Defense }\end{array}$ & Hawthorne, US & $\$ 12.0 \mathrm{bn}$ & $\begin{array}{l}4.000 \\
\text { employees }\end{array}$ & $\begin{array}{l}\text { The main user of } \\
\text { SpaceX is the } \\
\text { National } \\
\text { Aeronautics and } \\
\text { Space } \\
\text { Administration } \\
\text { (NASA), as well } \\
\text { as few other minor } \\
\text { entities such as the } \\
\text { United State } \\
\text { Airforce }\end{array}$ \\
\hline Pinterest & January 1, 2009 & $\begin{array}{l}\text { It is a visual discovering and } \\
\text { planning tool. Users use the } \\
\text { site and apps to get ideas for } \\
\text { the future, such as recipes, } \\
\text { places to travel, product to } \\
\text { buy and save the things they } \\
\text { love on their own board }\end{array}$ & $\begin{array}{l}\text { Consumer } \\
\text { Internet }\end{array}$ & San Francisco, US & $\$ 12.0 \mathrm{bn}$ & $\begin{array}{c}500+ \\
\text { employees }\end{array}$ & $\begin{array}{l}176 \text { million } \\
\text { registered users. } \\
\text { The } 85 \% \text { of them } \\
\text { are female }\end{array}$ \\
\hline Dropbox & June 1, 2007 & $\begin{array}{l}\text { Personal cloud storage } \\
\text { provider. It is used for file } \\
\text { sharing and collaboration in } \\
\text { order to be more productive }\end{array}$ & $\begin{array}{l}\text { Software, Data } \\
\text { Storage }\end{array}$ & San Francisco, US & $\$ 10.0$ bn & $\begin{array}{l}1.200 \\
\text { employees } \\
\text { (April 2015) }\end{array}$ & $\begin{array}{l}\text { June } 2015 \\
\text { registered } 400 \\
\text { million users }\end{array}$ \\
\hline Lufax & September, 2011 & $\begin{array}{l}\text { Online marketplace for } \\
\text { trading of financial assets }\end{array}$ & $\begin{array}{c}\text { Financial } \\
\text { Services, Internet }\end{array}$ & Shanghai, CN & $\$ 9.6$ bn & $\begin{array}{l}\text { Between } 500 \\
\text { and } 1.000 \\
\text { employees }\end{array}$ & $\begin{array}{c}\text { June } 2016 \\
\text { registered more } \\
\text { than } 10 \text { million } \\
\text { users and } \\
\text { transactions grew } \\
\text { more than } 8 \text { times } \\
\text { year on year } \\
\end{array}$ \\
\hline Theranos & 2003 & $\begin{array}{c}\text { The mission of the company } \\
\text { is to make actionable health } \\
\text { information accessible to } \\
\text { everyone at the time it } \\
\text { matters }\end{array}$ & $\begin{array}{l}\text { Biotechnology, } \\
\text { Health care and } \\
\text { Health } \\
\text { Diagnostics }\end{array}$ & Palo Alto, US & $\$ 9.0$ bn & $\begin{array}{c}500+ \\
\text { employees }\end{array}$ & $\begin{array}{c}\text { Theranos } \\
\text { performed more } \\
\text { than } 6 \text { million of } \\
\text { tests }\end{array}$ \\
\hline Spotify & July 14,2006 & $\begin{array}{l}\text { Commercial music streaming } \\
\text { service providing digital } \\
\text { rights to content record labels }\end{array}$ & $\begin{array}{l}\text { Music, Video } \\
\text { streaming, Cloud } \\
\text { computing, } \\
\text { Entertainment }\end{array}$ & Stockholm, SE & $\$ 8.5$ bn & $\begin{array}{c}1.354 \\
\text { employees }\end{array}$ & $\begin{array}{c}\text { June } 2015 \\
\text { registered a } \\
\text { number of active } \\
\text { users of over } 75 \\
\text { million. } \\
\text { Subscribers are } \\
\text { over } 20 \text { million. } \\
\text { It's available in } 58 \\
\text { markets } \\
\end{array}$ \\
\hline DJI & November, 2006 & $\begin{array}{l}\text { Produces commercial and } \\
\text { recreational unmanned aerial } \\
\text { systems. It is the largest } \\
\text { world consumer drone with a } \\
70 \% \text { of global market share }\end{array}$ & $\begin{array}{l}\text { Technology, } \\
\text { Consumer } \\
\text { Electronics }\end{array}$ & Shenzhen, CN & $\$ 8.0$ bn & $\begin{array}{l}3.000 \\
\text { employees }\end{array}$ & $\begin{array}{l}\text { In } 2014 \text { they sold } \\
\text { around } 416.000 \\
\text { drones }\end{array}$ \\
\hline $\begin{array}{l}\text { Zhong An } \\
\text { Online }\end{array}$ & 2003 & $\begin{array}{l}\text { Internet-based insurance } \\
\text { company data }\end{array}$ & Insurance & Shanghai, CN & $\$ 8.0$ bn & $\begin{array}{l}\text { Between } \\
100 \text { and } 499 \\
\text { employees }\end{array}$ & $\begin{array}{l}\text { March } 2016 \\
\text { registered } 0.39 \\
\text { billion of users } \\
\text { and the company } \\
\text { issued over } 4.17 \\
\text { insurances }\end{array}$ \\
\hline UberChina & 2015 & $\begin{array}{l}\text { Transportation platform that } \\
\text { links passengers and drivers } \\
\text { through a mobile app }\end{array}$ & Transportation & San Francisco, US & $\$ 7.0 \mathrm{bn}$ & 200 employees & $\begin{array}{l}1 \text { million daily } \\
\text { rides registered } \\
\text { between the } \\
\text { summer } 2015 \text { and } \\
\text { January } 2016\end{array}$ \\
\hline
\end{tabular}




\begin{tabular}{|c|c|c|c|c|c|c|c|}
\hline Lyft & January 1,2012 & $\begin{array}{l}\text { Peer-to-peer transportation } \\
\text { platform that connects } \\
\text { passengers who need rides } \\
\text { with drivers willing to } \\
\text { provide rides using their own } \\
\text { personal vehicles }\end{array}$ & Transportation & San Francisco, US & $\$ 5.5$ bn & $\begin{array}{l}\text { Between } 251 \\
\text { and } 500 \\
\text { employees }\end{array}$ & $\begin{array}{c}100.000 \text { registered } \\
\text { users }\end{array}$ \\
\hline Stripe & 2010 & $\begin{array}{c}\text { Set of tools that instantly } \\
\text { enable businesses to accept } \\
\text { and manage online payments }\end{array}$ & $\begin{array}{c}\text { Software, } \\
\text { Payments, Credit } \\
\text { Cards } \\
\end{array}$ & San Francisco, US & $\$ 5.0$ bn & 359 employees & $+1,5$ billion \\
\hline $\begin{array}{c}\text { OLA Cabs (ANI } \\
\text { Technologies) }\end{array}$ & $\begin{array}{l}\text { December 3, } \\
2010\end{array}$ & $\begin{array}{l}\text { India's most popular mobile } \\
\text { app for cab booking, with a } \\
200.000 \text { rides on its platform } \\
\text { per day across } 22 \text { cities }\end{array}$ & $\begin{array}{c}\text { E-commerce, } \\
\text { Transportation, } \\
\text { Internet, Mobile } \\
\text { commerce, } \\
\text { Automotive }\end{array}$ & Kolkata, IN & $\$ 5.0 \mathrm{bn}$ & $\begin{array}{l}\text { Between } 5.000 \\
\text { and } 10.000 \\
\text { employees }\end{array}$ & n.a. \\
\hline Snapdeal & January 1, 2010 & $\begin{array}{c}\text { Online marketplace offering } \\
\text { best priced deals on branded } \\
\text { products such as mobiles, } \\
\text { electronics, apparel and } \\
\text { accessorize }\end{array}$ & E-commerce & New Delhi, IN & $\$ 5.0 \mathrm{bn}$ & $\begin{array}{c}5.000+ \\
\text { employees }\end{array}$ & 25 million users \\
\hline Stemcentrx & $\begin{array}{l}\text { September 9, } \\
2015\end{array}$ & $\begin{array}{l}\text { Develops therapies and } \\
\text { diagnostics for cancer } \\
\text { patients, combining scientific } \\
\text { talent from the world's } \\
\text { leading academic labs and } \\
\text { enterprises }\end{array}$ & HealthCare & San Francisco, US & $\$ 5.0$ bn & 200 employees & n.a. \\
\hline Magic Leap & 2011 & $\begin{array}{l}\text { Develops Mixed Reality } \\
\text { computing platform that } \\
\text { enables users to interact with } \\
\text { the world; and Dynamic } \\
\text { Digitized Light field Signal, } \\
\text { which enables users to } \\
\text { generate images from real } \\
\text { objects and then place those } \\
\text { images into the real world }\end{array}$ & $\begin{array}{l}\text { Hardware, } \\
\text { Software }\end{array}$ & Dania, US & $\$ 4.5 \mathrm{bn}$ & $\begin{array}{l}\text { Between } 250 \\
\text { and } 500 \\
\text { employees }\end{array}$ & n.a. \\
\hline Zenefits & May 6, 2015 & $\begin{array}{l}\text { Helps managing and } \\
\text { automating all HR-from } \\
\text { payroll to benefits through an } \\
\text { online dashboard }\end{array}$ & Software & San Francisco, US & $\$ 4.5 \mathrm{bn}$ & $\begin{array}{c}1.600 \\
\text { employees }\end{array}$ & $\begin{array}{l}10.000+ \\
\text { companies as } \\
\text { users }\end{array}$ \\
\hline Cloudera & October 13, 2008 & $\begin{array}{c}\text { Develops and distributes } \\
\text { software based on Hadoop } \\
\text { that powers the data } \\
\text { processing engine of the } \\
\text { world's largest and most } \\
\text { popular web sites } \\
\end{array}$ & Software & Palo Alto, US & $\$ 4.1 \mathrm{bn}$ & $\begin{array}{c}1.000+ \\
\text { employees }\end{array}$ & 525 users \\
\hline $\begin{array}{c}\text { SoFi } \\
\text { (Social Finance) }\end{array}$ & 2011 & $\begin{array}{l}\text { Marketplace lender that } \\
\text { provides student loan } \\
\text { refinancing, mortgages and } \\
\text { other types of loans, such as } \\
\text { parent and personal loans. } \\
\text { The company is a non-bank } \\
\text { alternative focused on } \\
\text { offering loans at lower rates } \\
\text { than traditional lenders. } \\
\text { SoFi's primary customers are } \\
\text { early stage professionals }\end{array}$ & $\begin{array}{c}\text { Financial } \\
\text { Services }\end{array}$ & San Francisco, US & $\$ 4.0 \mathrm{bn}$ & 500 employees & 3 billion users \\
\hline Slack & January 1, 2013 & $\begin{array}{l}\text { Team communication } \\
\text { application providing } \\
\text { services such as real-time } \\
\text { messaging, archiving, and } \\
\text { search for modern teams }\end{array}$ & Software & San Francisco, US & $\$ 3.8$ bn & $\begin{array}{l}125 \text { employees } \\
\text { (from the } 8 \\
\text { employees of } \\
\text { the 2014) }\end{array}$ & $\begin{array}{c}\text { More than } 1.7 \\
\text { million users } \\
\text { connected at the } \\
\text { same time } \\
\text { (October 2015) }\end{array}$ \\
\hline Garena Online & 2009 & $\begin{array}{c}\text { Garena distributes game titles } \\
\text { on Garena+ in various } \\
\text { countries across Southeast } \\
\text { Asia and Taiwan. It is the } \\
\text { biggest Web and mobile } \\
\text { platform in the South-east } \\
\text { Asia offering hits like League } \\
\text { of Legends and FIFA Online } \\
\text { 3. }\end{array}$ & $\begin{array}{l}\text { Consumer } \\
\text { Internet }\end{array}$ & Singapore, SG & $\$ 3.8$ bn & $\begin{array}{c}4.500 \\
\text { employees }\end{array}$ & $\begin{array}{l}17 \text { million pc } \\
\text { users, } 14 \text { million } \\
\text { mobile users }\end{array}$ \\
\hline Credit Karma & June 1, 2007 & $\begin{array}{l}\text { Offers free access to credit } \\
\text { reports and scores, } \\
\text { personalized financial } \\
\text { recommendations and } \\
\text { educational resources }\end{array}$ & $\begin{array}{c}\text { Financial } \\
\text { Services }\end{array}$ & San Francisco, US & $\$ 3.5$ bn & 250 employees & 21 million users \\
\hline Tanium & 2007 & $\begin{array}{c}\text { Tanium is a security and } \\
\text { systems management } \\
\text { solution that allows real-time } \\
\text { data collection at enterprise } \\
\text { scale }\end{array}$ & Software & Emeryville, US & $\$ 3.5$ bn & 175 employees & 10 million users \\
\hline $\begin{array}{l}\text { Global Fashion } \\
\text { Group }\end{array}$ & 2011 & $\begin{array}{l}\text { Brings fashion online in } \\
\text { emerging markets. It is active } \\
\text { across } 27 \text { countries }\end{array}$ & E-Commerce & Luxemburg, LU & $\$ 3.4$ bn & $\begin{array}{c}9.500 \\
\text { employees }\end{array}$ & $\begin{array}{l}5 \text { million active } \\
\text { subscribers }\end{array}$ \\
\hline UCar & 2014 & $\begin{array}{l}\text { UCar provides a chauffeured } \\
\text { car service in China }\end{array}$ & Transportation & Beijing, CN & $\$ 3.4$ bn & $\begin{array}{l}\text { Between } 250 \\
\text { and } 500 \\
\text { employees } \\
\end{array}$ & $\begin{array}{c}466.520 \text { active } \\
\text { users }\end{array}$ \\
\hline Delivery Hero & May 1, 2011 & $\begin{array}{c}\text { Online food and beverage- } \\
\text { ordering service operating } \\
\text { internationally in } 29 \\
\text { countries }\end{array}$ & $\begin{array}{l}\text { Consumer } \\
\text { Internet }\end{array}$ & Berlin, DE & $\$ 3.1 \mathrm{bn}$ & $\begin{array}{c}1.000+ \\
\text { globally, } 400 \\
\text { from its Berlin } \\
\text { headquarter }\end{array}$ & $\begin{array}{l}9.56 \text { million of } \\
\text { food orders in } \\
2012\end{array}$ \\
\hline
\end{tabular}




\begin{tabular}{|c|c|c|c|c|c|c|c|}
\hline$V A N C L$ & 2007 & $\begin{array}{c}\text { Internet apparel brand in } \\
\text { China providing men and } \\
\text { women fashion products such } \\
\text { as shoes, jeans, shirts, skirts, } \\
\text { accessories, and other } \\
\text { lifestyle goods at reasonable } \\
\text { prices. Its product designers } \\
\text { come from around the globe, } \\
\text { including Spain, Japan, and } \\
\text { Korea } \\
\end{array}$ & E-commerce & Beijing, CN & $\$ 3.0 \mathrm{bn}$ & $\begin{array}{l}2.000 \\
\text { employees }\end{array}$ & $\begin{array}{l}10 \text { million } \\
\text { registered users }\end{array}$ \\
\hline Fanatics & 1995 & $\begin{array}{l}\text { Market leader for officially } \\
\text { licensed sports merchandise } \\
\text { that provides the ultimate } \\
\text { shopping experience to sports } \\
\text { fans. It operates in more than } \\
300 \text { online and offline stores }\end{array}$ & E-commerce & Jacksonville, US & $\$ 3.0 \mathrm{bn}$ & $\begin{array}{c}1.500+ \\
\text { employees }\end{array}$ & n.a. \\
\hline DocuSign & 2003 & $\begin{array}{c}\text { DocuSign helps } \\
\text { organizations of every size, } \\
\text { industry and geography to go } \\
\text { digital by empowering } \\
\text { anyone to transact anything, } \\
\text { anytime, anywhere, on any } \\
\text { device } \\
\end{array}$ & Software & San Francisco, US & $\$ 3.0 \mathrm{bn}$ & $\begin{array}{l}1.000 \\
\text { employees }\end{array}$ & 85 million users \\
\hline Moderna & 2010 & $\begin{array}{l}\text { Pioneering messenger RNA } \\
\text { therapeutics }{ }^{\mathrm{TM}} \text { that produces } \\
\text { human proteins or antibodies } \\
\text { inside patient cells, which are } \\
\text { in turn active intracellularly } \\
\text { or secreted. This } \\
\text { breakthrough platform } \\
\text { addresses currently } \\
\text { undruggable targets, and } \\
\text { offers a superior alternative } \\
\text { to existing drug modalities } \\
\text { for a wide range of disease } \\
\text { conditions }\end{array}$ & Healthcare & Cambridge, US & $\$ 3.0 \mathrm{bn}$ & 300 employees & n.a. \\
\hline $\begin{array}{c}\text { Wish } \\
\text { (ContextLogic) }\end{array}$ & 2011 & $\begin{array}{l}\text { Wish is the leading mobile } \\
\text { commerce platform in North } \\
\text { America and Europe. Its } \\
\text { mission is to give everyone } \\
\text { access to the most affordable, } \\
\text { convenient, and effective } \\
\text { shopping mall in the world }\end{array}$ & E-commerce & San Francisco, US & $\$ 3.0 \mathrm{bn}$ & 120 employees & 12 million users \\
\hline Ele.me & 2008 & $\begin{array}{l}\text { Website that offers customer- } \\
\text { to-customer meal ordering } \\
\text { services. It also acts as a } \\
\text { communication platform } \\
\text { between users and restaurants }\end{array}$ & $\begin{array}{l}\text { Consumer } \\
\text { Internet }\end{array}$ & Shanghai, CN & $\$ 3.0$ bn & n.a. & $\begin{array}{l}40 \text { million users } \\
\text { and } 300.000 \\
\text { subscribed } \\
\text { restaurant }\end{array}$ \\
\hline HelloFresh & 2012 & $\begin{array}{l}\text { HelloFresh is a new way to } \\
\text { cook. Every week, you can } \\
\text { pick the delicious recipes you } \\
\text { want to try and they will send } \\
\text { you amazing recipes and all } \\
\text { of the ingredients you need to } \\
\text { prepare them }\end{array}$ & $\begin{array}{l}\text { Consumer } \\
\text { Internet }\end{array}$ & Germany, DE & $\$ 2.9$ bn & $\begin{array}{l}\text { Between } 100 \\
\text { and } 250 \\
\text { employees }\end{array}$ & $\begin{array}{l}4 \text { million meals } \\
\text { per month }\end{array}$ \\
\hline Bloom Energy & 2001 & $\begin{array}{l}\text { Offers on-site power } \\
\text { generation systems that can } \\
\text { use a wide variety of inputs } \\
\text { to generate electricity. The } \\
\text { founder discovers the way to } \\
\text { convert Martian atmospheric } \\
\text { gases to oxygen for } \\
\text { propulsion and life support. It } \\
\text { built a fuel cell capable of } \\
\text { producing air and fuel from } \\
\text { electricity generated by a } \\
\text { solar panel }\end{array}$ & Energy & Sunnyvale, US & $\$ 2.9$ bn & $\begin{array}{l}\text { Between } 500 \\
\text { and } 1.000 \\
\text { employees }\end{array}$ & $\begin{array}{l}\text { More than } 70 \\
\text { multinational } \\
\text { firms registered in } \\
\text { the website }\end{array}$ \\
\hline Powa & 2007 & $\begin{array}{c}\text { Powa is a commerce } \\
\text { specialist that creates } \\
\text { technologies to seamlessly } \\
\text { integrate the physical and } \\
\text { digital world } \\
\end{array}$ & $\begin{array}{l}\text { Technology } \\
\text { retailer; E- } \\
\text { commerce, } \\
\text { Mobile payments }\end{array}$ & London, UK & $\$ 2.7$ bn & $\begin{array}{l}\text { Between } 100 \\
\text { and } 250 \\
\text { employees }\end{array}$ & $\begin{array}{c}1.200 \text { companies } \\
\text { as users }\end{array}$ \\
\hline $\begin{array}{l}\text { Oscar Health } \\
\text { Insurance }\end{array}$ & July 1, 2013 & $\begin{array}{l}\text { Health insurance company } \\
\text { that uses technology, design } \\
\text { and data to humanize health } \\
\text { care }\end{array}$ & $\begin{array}{l}\text { Health care and } \\
\text { insurance }\end{array}$ & New York, US & $\$ 2.7$ bn & $\begin{array}{l}\text { April } 2015 \\
\text { registered } 185 \\
\text { employees; } \\
\text { (LinkedIn } \\
\text { estimates } \\
\text { between } 200 \\
\text { and } 500 \\
\text { employees) } \\
\end{array}$ & $\begin{array}{l}\text { September } 2015 \\
\text { registered } 40.000 \\
\text { users in New York } \\
\text { and New Jersey }\end{array}$ \\
\hline InMobi & 2007 & $\begin{array}{c}\text { Mobile platform allowing } \\
\text { brands, developers and } \\
\text { publishers to engage } \\
\text { consumers through mobile } \\
\text { advertising } \\
\end{array}$ & $\begin{array}{l}\text { Mobile, } \\
\text { Advertising }\end{array}$ & Bangalore, IN & $\$ 2.5$ bn & $\begin{array}{l}\text { Between } 500 \\
\text { and } 1.000 \\
\text { employees }\end{array}$ & $\begin{array}{c}\text { February } 2014 \\
\text { registered } 759 \\
\text { million active } \\
\text { users in over } 200 \\
\text { countries } \\
\end{array}$ \\
\hline Mozido & 2008 & $\begin{array}{l}\text { Global provider of trusted } \\
\text { and inclusive digital } \\
\text { commerce and payment } \\
\text { solutions for both unbacked } \\
\text { and developed markets }\end{array}$ & $\begin{array}{l}\text { E-commerce, } \\
\text { Mobile and } \\
\text { Enterprise } \\
\text { software }\end{array}$ & Austin, US & $\$ 2.4$ bn & $\begin{array}{l}\text { Between } 500 \\
\text { and } 1.000 \\
\text { employees }\end{array}$ & $\begin{array}{l}\text { Mozido expected } \\
\text { early adoption } \\
\text { numbers of } \\
\text { around } 50.000 \\
\text { users by the end } \\
\text { of } 2014 \\
\end{array}$ \\
\hline Houzz & 2009 & $\begin{array}{l}\text { Platform for home } \\
\text { remodeling and design, } \\
\text { providing people all the tools }\end{array}$ & Home renovation & Palo Alto, US & $\$ 2.3$ bn & $\begin{array}{l}\text { Between } 800 \\
\text { and } 1.000 \\
\text { employees }\end{array}$ & $\begin{array}{l}\text { Millions of home } \\
\text { owners, } 250.000 \\
\text { among architects, }\end{array}$ \\
\hline
\end{tabular}




\begin{tabular}{|c|c|c|c|c|c|c|c|}
\hline & & $\begin{array}{l}\text { they need to improve their } \\
\text { home online or from a } \\
\text { mobile }\end{array}$ & & & & & $\begin{array}{c}\text { designers and } \\
\text { contractors; } 35 \\
\text { monthly unique } \\
\text { users } \\
\end{array}$ \\
\hline Adyen & 2006 & $\begin{array}{l}\text { Multichannel payment } \\
\text { company that provides } \\
\text { businesses with a single } \\
\text { solution to accept payments } \\
\text { anywhere in the world }\end{array}$ & Payments & Amsterdam, NL & $\$ 2.3 \mathrm{bn}$ & 300 employees & $\begin{array}{l}4.500 \text { customers } \\
\text { (such as } \\
\text { Facebook, } \\
\text { Drobox, Netflix, } \\
\text { Spotify, } \\
\text { Vodafone, } \\
\text { Mango) } \\
\end{array}$ \\
\hline DraftKings & 2011 & $\begin{array}{c}\text { Daily fantasy sports website } \\
\text { where you can play against } \\
\text { your friends } \\
\end{array}$ & $\begin{array}{l}\text { Fantasy Sports, } \\
\text { Sports }\end{array}$ & Boston, US & $\$ 2.1 \mathrm{bn}$ & $\begin{array}{l}\text { Between } 100 \\
\text { and } 250 \\
\text { employees } \\
\end{array}$ & 1 million users \\
\hline Trendy Group & 1999 & $\begin{array}{l}\text { Innovative fashion and } \\
\text { lifestyle retail corporation } \\
\text { that renowned for its perfect } \\
\text { union of art and business }\end{array}$ & Fashion & Guangzhou, CN & $\$ 2.0 \mathrm{bn}$ & $\begin{array}{l}\text { Between } 5.000 \\
\text { and } 10.000 \\
\text { employees }\end{array}$ & n.a. \\
\hline
\end{tabular}

\subsection{HISTORICAL ANALYSIS METHODOLOGY}

From an empirical point of view, we have conducted the analysis by applying the historical analysis methodology (Gottschalk, 1969; Urbinati, et al., 2018a, 2018b). Historical analysis has been conducted by "assembling, critically examining, and summarizing the records of the past" (Chiesa \& Frattini, 2011, p. 443). Information gathered from published sources on a sample of Unicorn-tech companies, the first 50 innovations in terms of market capitalization, was analyzed. We chose historical analysis because it offers a number of advantages over surveys or case studies conducted through direct interviews, which make it particularly suited to the purpose of this article. First, historical analysis relies on information collected when our sample of Unicorns appeared into the market for the first time. Second, it is particularly "appropriate for studying the chronological dimension of past events" (Chiesa \& Frattini, 2011, p. 443), as in our case. Third, the information is gathered from multiple sources. We continuously compared data on our sample of Unicorns each other, by applying single-case study and cross-case comparisons and triangulated with other sources of information.

\subsection{PROCEDURE}

For our historical analysis, we have used as primary sources the main economic journals that have documented the development and diffusion of these innovations since their birth. The choice to select more articles from different sources facilitated both single-case study analysis and cross-case comparisons. Above all, this procedure was used to check that the same information was corroborated by other different sources. In addition, a traditional content analysis (Weber, 1990) was performed on the material gathered, to cluster the information contained in each business model of the analyzed companies. We also applied the control criteria for the historical analysis proposed by Golder and Tellis (1993), which allow to overcome all the problems associated to this methodology, which "implies a certain unavoidable level of uncertainty, because the researcher is confronted with complex and sometimes contradictory empirical evidence" (Chiesa \& Frattini, 2011, p. 446). Therefore, each author previously conducted independently the analysis of the documents and the cross-case comparisons among the collected material. In a second moment, then, the authors clustered all the accepted information, after they had contrasted their own interpretations on the business model design and innovation choices of the analyzed innovations.

The most helpful and frequently referenced economic journals were Bloomberg, Business Insider, Forbes, Fortune, The Economist, The Financial Times, The New York Times, and The Wall Street Journal, which were searched using the LexisNexis web-based, professional full-text journal database.

We created a dedicated archive, where listed each Unicorn of our sample, and highlighted for each of them the following information, which were also useful to depict the relative Business Model Canvas:

- Date of foundation

- Service offered 
- Industry

- Headquarter

- Latest valuation (bn \$)

- Typology and Number of employees

- Typology and Number of users

- Investors

- Competitors

- Partnership and acquisition

- Scalable business model

- Network effects

- Interconnected social platform

- Switching costs

- Customized offering (differentiating for B2B or B2C markets)

Finally, we involved a panel of experts of business model design, business model innovation and innovation diffusion to discuss with them on the material collected from our empirical analysis and on the validity of our findings. This panel was made of three Professors of Strategy and Innovation Management of the School of Management of Politecnico di Milano (Italy) and two managers working in the Italian headquarter of one of the companies of our sample. With each of them, we conducted face-to-face meetings at least twice for an average of one hour and half (for over 15 hours of interviews), and analyzed the results ensuing from the collected material. The involvement of experts allowed us to refine our analysis, and to work on the connections between the empirical evidence and theoretical setting.

The results ensuing from applying the historical analysis and the procedure explained above are summarized and discussed in the following Section 4.

\section{RESULTS AND DISCUSSION}

From the analysis of the business model of each Unicorn of our sample, summarized in Table 1A of the Appendix ("The business model of the sampled Unicorns"), it emerges how these companies rely on peculiar business model design and innovation choices that profoundly influence the speed and the patterns of diffusion of the innovations they have launched and commercialized.

We clustered into two business model configurations, named "Larger Partners Ecosystem" and "Smaller Partners Ecosystem", the business model design and innovation choices we refer to (see Figure 2). The business model configuration of "Larger Partners Ecosystem" is characterized by a high number of upstream (suppliers) and downstream (users) partners, who allow the Unicorns of this configuration to access to several technological inputs and diversify their offer portfolio for their users, who obtain cross-side exchange benefits. On the other hand, the business model configuration of "Smaller Partners Ecosystem" is characterized by a small number of upstream partners (mostly), who allow the Unicorns of this configuration to access to specific technological inputs and to develop a narrow offer for their users, who obtain same-side exchange benefits.

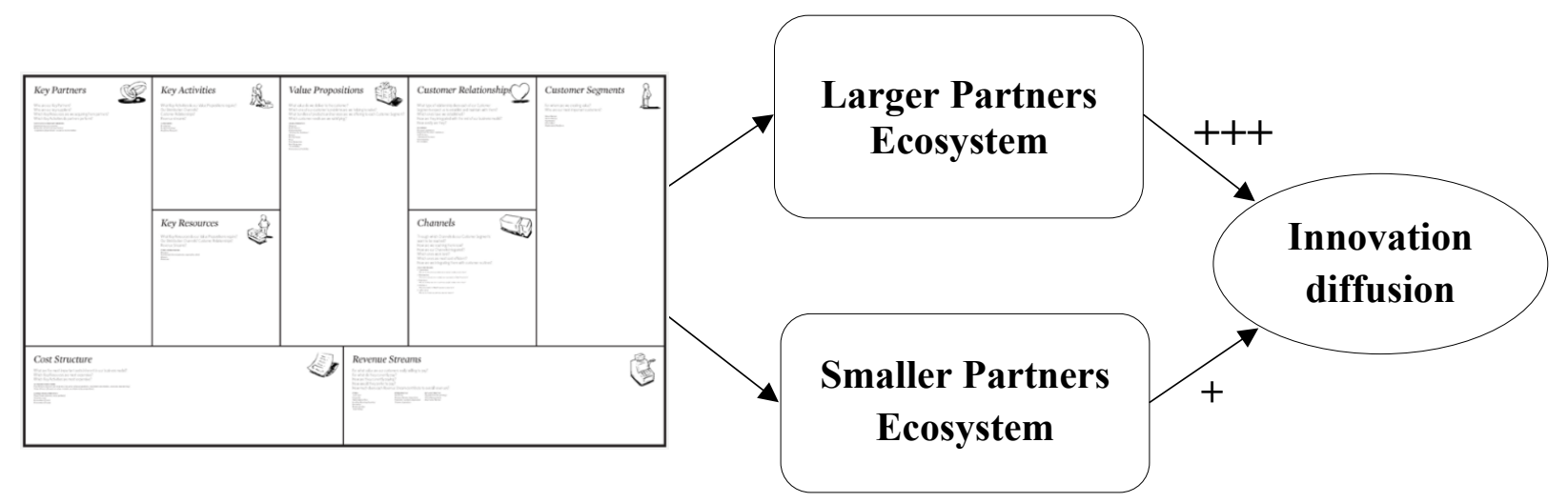


Figure 2: "Larger Partners Ecosystem" and "Smaller Partners Ecosystem” business model configurations.

We provide hereafter a thorough analysis of the two business model configurations, by highlighting their main characteristics in terms of (i) business model design and innovation choices, (ii) cross-side and same-side exchange benefits generated by the different types of network effects that these business model configurations enable, and (iii) speed of diffusion.

\subsection{BUSINESS MODEL CONFIGURATIONS}

\section{LARGER PARTNERS ECOSYSTEM}

Value network: a preliminary analysis on the number and on the typology of partnerships that each Unicorn of our sample established provides interesting and relevant information. The results show that the higher number of partnerships built by the "Larger Partners Ecosystem" companies, rather than "Smaller Partners Ecosystem" ones, allowed them to provide a higher number of products and services included in the offer. For instance, Uber has established partnerships with six different categories of partners, such as hotel chains, non-governmental organizations (NGOs), car rental companies, car manufactures companies, and companies that provide complementary intangible services. All these actors have allowed Uber to provide a more extensive and effective offer for its users. Accordingly, from the interaction with hotel chains, Uber's end-consumers gain special discounts for the accommodation, whereas the interaction with NGOs allows the company to gain reliability of its brand reputation. In addition, car rental companies and car manufacturers supply the right cars for specific services provided by the company. Finally, complementary intangible services companies furnish those assets, such as electronic payment system or double rating system, which increase the customer's experience. Similarly, Airbnb, the famous online reservation platform, has established partnerships clustered in four main categories. The first one is "serving the public", to provide accommodation for free addressed to volunteers' members. The second consists in "building the brand" to accessorize each location with distinctive and recognisable features, such as songs, which enhance the brand identity. The third category is "connecting the community", which aims to link the offer of the company with others communication channels. The last one consists in "saving the environment" to underline the green reputation of the company. Another important information ensuing from the analysis is related to the key resources. In the "Larger Partners Ecosystem" Unicorns, key resources are represented both by the two or more groups of different users (such as drivers and passengers in the case of Uber) and by the platform that allows matching their requests. As reported in the Accenture report of 2016 titled "Platform Economy: technology driven business model innovation from the outside in", from some interviews conducted with digital leaders across different industries emerge that the " $40 \%$ of them believe that adopting a platform-based business model and engaging in an ecosystem of digital partners are very critical to their business success". For instance, Flipkart bases its business on a platform that allows the connection between sellers and buyers. The formers represent the key resources within the company, because without them the service would not work, as they provide key categories of products (electronics, men, women, baby\&kids, home\&furniture, books\&media, auto\&sports) that are offered to the company's buyers.

Customer Value Proposition \& Interface: the platform plays the key role of distribution and communication channel. For example, Delivery Hero is based on a platform through which clients 
purchase meals and interact with restaurants that simultaneously gain visibility from their offer. In addition, the platform allows clients to have many choices of meals in a same marketplace instead of searching in each restaurant's website. As far as the value proposition is concerned, the "Larger Partners Ecosystem" companies provide an offer highly diversified both in terms of number of categories of products and in terms of number of products within each category. For instance, Global Fashion Group has a wide portfolio of brands and a high number of products within each of them. Ola Cabs is another useful example. Leader in the Indian market of taxi service, the company offers a numerous range of different services for different typologies of users. Ola Shuttle, Taxiforsure and Local taxi are suitable for the transportation of final users, Ola Corporate is specific for business travellers, and Ola Money is the online wallet that allows clients to pay directly through their registered personal account. The customer relationship relates to the "Larger Partners Ecosystem" business model configuration is highly customized, and this allows meeting the clients' expectation in the best possible way. For instance, Pinterest is a social network where users, after the registration, can see only those pins that belong to their favourite categories. This is also the case of Snapdeal, the online retailer company that gives its customers the possibility to select the only services that correspond to the range of price they have selected.

\section{SMALLER PARTNERS ECOSYSTEM}

Value Network: "Smaller Partners Ecosystem" companies have established a lower number of relationships rather than "Larger Partners Ecosystem" ones, and manly based on the acquisition of technological inputs required for the realization of products or services. In this respect, these companies do not need to establish partnerships with a high number and a different typology of partners, and this aspect is indirectly reflected in a less rich offer of categories of products. For instance, Palantir, the data analytics company, has established partnerships, on the one hand, with data providers to enrich its data platform with customers' data and, on the other hand, with few providers of complementary intangible services. The clients' network is the most important resource for "Smaller Partners Ecosystem" companies. Clients allow through their word-of-mouth effect to increase the user base and spread the service of this business model configuration. In this case, a further example is Snapchat, a social network for instant chatting and messaging, which significantly leverages on its clients' network. Indeed, the more are the Snap chatters, the more attractive is the service for users.

Customer Value Proposition \& Interface: the main channel, used by the "Smaller Partners Ecosystem" companies, is usually represented by the website where the end consumers can see and buy the company's offer. For instance, DJI displays all the information about its products with respective prices to foster the buying process. Moreover, in the website there are several forums where clients can leave comments or feedbacks about their experience. However, not all the companies belonging to the "Smaller Partners Ecosystem" business model configuration use the website to this aim. Indeed, SpaceX, the aerospace and defence company, is an example of Unicorn that uses the website just as a communication channel. The website of the company indeed shows projects and initiatives, without any prices and without allowing clients to leave comments or similar. The value proposition is focused on few categories of products or services. Zenefits, for example, offers a small range of functionalities for the HR management, all of them grouped in one product package. In addition, DocuSign, a software company, offers only the availability to sign documents for organizations of every size, industry and geography, only in electronic way. The customer relationship is mainly standardized because the offer has not the possibility to be personalized according to specific needs and preferences of users. For instance, Dropbox, the data storage company, offers to its customers only packages of fixed GB. In this way, if clients wanted an intermediate or a customized solution, they could not have any opportunity. For instance, if they wanted an amount of additional GB, which is not provided in a specific package, they should buy a higher amount of GB. 
Accordingly, in terms of the business model design and innovation choices of the "Larger Partners Ecosystem" and "Smaller Partners Ecosystem" business model configurations, the economic model does not seem to be a differential factor.

Table 2 summarizes the main similarities (within each configuration) and the differences between the two business model configurations on which the Unicorns in our sample rely.

Table 2: "Larger Partners Ecosystem" vs. "Smaller Partners Ecosystem" business model configurations in terms of business model design and innovation choices.

\begin{tabular}{|c|ll|l|}
\hline & \multicolumn{1}{|c|}{ "Larger Partners Ecosystem" } & \multicolumn{1}{c|}{ "Smaller Partners Ecosystem" } \\
\hline & $\bullet \begin{array}{l}\text { High number of partners involved belonging to } \\
\text { different industries } \\
\text { Key resources are represented by two (or more) } \\
\text { different groups of users that exploit cross- } \\
\text { exchange benefits among each other and by the } \\
\text { pusiness } \\
\begin{array}{c}\text { Model } \\
\text { (Canvas) } \\
\text { Configuration }\end{array}\end{array}$ & $\begin{array}{l}\text { - } \\
\text { Diversified offer with a high number of different } \\
\text { products and services }\end{array}$ & $\begin{array}{l}\text { Low number of partners involved mainly } \\
\text { represented by upstream suppliers } \\
\text { Key resources are represented by only one } \\
\text { group of users (i.e. end-consumers) that benefit } \\
\text { from same-side network effects }\end{array}$ \\
& $\bullet \begin{array}{l}\text { Focused offer with a low number of different } \\
\text { pustomized customer relationship } \\
\text { The platform works as a distribution and services } \\
\text { communication channel }\end{array}$ & $\begin{array}{l}\text { Standardized customer relationship } \\
\text { The website works as a distribution and } \\
\text { communication channel }\end{array}$ \\
\hline
\end{tabular}

\subsection{NETWORK EFFECTS}

\section{CROSS-SIDE EXCHANGE BENEFITS}

Moreover, we note that companies relying on a "Larger Partners Ecosystem" business model configuration, such as Uber, Didi Kuaidi, and Airbnb, allow two (or more) different groups of users to obtain cross-side exchange benefits interacting each other, i.e. drivers and passengers in the case of Uber and Didi Kuaidi, or homeowners and travellers in the case of Airbnb. Accordingly, the first group of users usually is represented by the providers of the assets or complementary services (such as the drivers in the case of Uber); whereas the second group of users is represented by the endconsumers who want to benefit from the offer of these assets or services (such as the passengers in the case of Uber). These two groups share their needs on interconnected social platforms, which allow them to communicate, leave feedbacks and share information. As stated again in the above-mentioned Accenture report, "Business creates platform in which customers, employees and partners can experience all the five senses, together, in any environment they choose. This leads to the early stage of the dematerialization where people can be present virtually anywhere in the world at any time and meet with their friends". Therefore, the providers earn revenues coming from each of the endconsumers, whereas end-consumers benefit from the availability of a wide offer. By doing so, innovator companies exploit the cross-side exchange benefits between the two (or more) groups of users to expand their user base and diffuse with greater speed. To this aim, innovator companies mainly focus on a high number of partners of different typology, i.e. upstream, downstream and sometimes belonging to other industries, who ensure a rapid growth of their platforms. 
On the other hand, companies relying on a "Smaller Partners Ecosystem" business model configuration, such as Xiaomi, Magic Leap, and Moderna, allow only one group of users to obtain same-side exchange benefits and exploit them to expand their user base and diffuse with greater speed into the market. Accordingly, this group of users usually is represented by the end-consumers who purchase the products or services of the companies and benefit from their offer. In this case, however, the innovator company does not act as a real marketplace, rather as a direct seller of its products or services. To this aim, the company mainly focuses on alliances with upstream suppliers that provide technological inputs required for the realization of its products or services, without the need to establish partnerships with a high number and a different typology of partners. For instance, Xiaomi has established partnership with NXP, which produces semiconductors and with Foxconn, which is an electronic components producer. Both these actors provide the main technological inputs that Xiaomi is not able to produce internally. In addition, Moderna Therapeutics has built relationships with research institutes to acquire more knowledge and high technical competencies necessary for the development of new drugs in the oncology industry.

\subsection{SPEED OF DIFFUSION}

In addition, we highlight in the following discussion how some Unicorns, belonging to the "Larger Partners Ecosystem" business model configuration, have reached a higher speed of diffusion than Unicorns belonging to "Smaller Partners Ecosystem" business model configuration. We do this, with the aim to show that the adoption of one or the other business model configuration influences at different extent the speed of diffusion of the digitally enabled innovations.

Indeed, we note how the number of Uber' drivers in US has grown by about $50 \%$ between 2014 and 2015, whereas the number of Airbnb's guests, who book in the summer time, is more than doubled within a year. The "Airbnb's Summer 2015 Report" indicates that the growth of guests over the past 5 years (2010-2015) for summer vacations has grown 353 times up to 17 million reservations. Moreover, during 2012, the user base of Pinterest has gone up from 9 million until about 40 million (more than $300 \%$ in a period of only one year), whereas the number of employees has grown from 20 until 100. This allowed the company to become the largest social media platform in users per employee. The dynamics of diffusions of these innovations explain also their financial growth in short time. For example, Uber at the end of 2015 has increased its market capitalization by around 126\% from the previous 6 months, Airbnb by around 300\% from the previous 18 months, and Pinterest by around $32 \%$ from the previous 7 months.

On the other side, companies such as Dropbox and Xiaomi, although have grown quickly in a few years, show percentages and speed of diffusion slightly smaller if compared with the Unicorns above. Xiaomi in the period 2015 has grown by only around 30\% over the previous period 2014, by selling around 80 million of smartphones compared with the 61.1 million of 2014 and the 18.7 million of 2013. Dropbox, instead, in the period 2013-2015 has had a stable growth of about $70-80 \%$, whereas was grown in 2012 of about the $152 \%$ compared to 2011 , and about $283 \%$ compared to 2010 . The dynamics of diffusions of these innovations explain also their financial growth in the short time, although with at a lower extent compared with the previous examples. For instance, Dropbox at the end of 2015 has increased its market capitalization by around $150 \%$ from the previous 28 months and Xiaomi by around $15 \%$ from the previous 24 months.

Although our sample of 50 Unicorns has grown quickly in a few years, and following a different trajectory compared to non-digitally based innovations, the "Larger Partners Ecosystem" business model configuration has allowed to launch and commercialize the innovations faster rather than the "Smaller Partners Ecosystem" business model configuration, as shown by the numbers above. Accordingly, the different speed of diffusion due to the "Larger Partners Ecosystem" and the "Smaller Partners Ecosystem" business model configurations, is respectively explained by the three "+" and the single "+" reported in the framework above. 


\section{CONCLUSIONS}

The paper aims to understand how different business model design and innovation choices can determine incredibly fast diffusion of new products and services enabled by digital technologies. To this aim, we have analyzed the business model of 50 Unicorn-tech companies, i.e. venture-backed private tech-companies that were able to determine incredibly fast diffusions of their digitally enabled innovations, have created incredibly fast diffusion processes and have built very successful businesses.

We have mapped two different configurations of business models and described the main business model design and innovation choices of our Unicorns within each configuration. We have called "Larger Partners Ecosystem" and "Smaller Partners Ecosystem" business model configurations each cluster of Unicorns. The business model configuration of "Larger Partners Ecosystem" is characterized by a high number of upstream (suppliers) and downstream (users) partners, who allow the Unicorns of this configuration to access to several technological inputs and diversify their offer portfolio for their users, who obtain cross-side exchange benefits. On the other hand, the business model configuration of "Smaller Partners Ecosystem" is characterized by a small number of upstream partners (mostly), who allow the Unicorns of this configuration to access to specific technological inputs and to develop a narrow offer for their users, who obtain same-side exchange benefits and pointed out their main key features. Finally, we have shown how some Unicorns, belonging to the "Larger Partners Ecosystem" business model configuration, have reached a higher speed of diffusion than some Unicorns belonging to "Smaller Partners Ecosystem" business model configuration. In so doing, we argue that the adoption of one or the other business model configuration influences at different extent the speed of diffusion of the digitally enabled innovations.

Although the findings of this exploratory research, due to the methodology that we used, cannot be generalized to any population of Unicorns or industries, we retain that our paper has important implications for managers and practitioners. First, this study hopefully gives some suggestions and real-world examples of how a business model can be designed or innovated to maximize the chance of realizing a very fast diffusion of new digital technology-based products or services. In addition, the findings of our paper are not only addressed to managers of big companies, with similar characteristics of the Unicorns, who are always looking for fast diffusion rates of their mainstream products and services, and business growth, to cause massive disruption, but also to those designers and engineers working for micro and small companies, or start-up companies, or innovative early stage ventures, who often struggle to make their mark in a world mostly dominated by the big players. Indeed, the papers invites managers of these companies to reflect on how several business model design and innovation choices, as the identification and selection of the typology of partners and users, or the composition of the value proposition, or the enabled network effects, can accelerate the diffusion of their products or services into the market. Thus, the paper suggests entrepreneurs of these small and micro companies, who usually establish their business model very early on, in a step-bystep process that conceives testing, collecting metrics and evaluating results, to interpret the goodness of a business model also in terms of speed of diffusion. In this way, in testing their business model, they can foresee how different business model design and innovation choices can potentially affect the diffusion of their innovations.

From a theoretical perspective, we attempt to give a new interpretation of the patterns of innovation diffusion arguing that new digitally enabled innovations diffuse into the market with a speed of diffusion that depends on the business model design and innovation choices of companies that have launched and commercialized them into the market, and therefore following a trajectory which is different compared to those explained by the traditional models of innovation diffusion, such as the S-curve. In addition, the paper adds to the research of digital business model (Pagani, 2013; Trapp, et al., 2018). Indeed, our Unicorns are mostly IT platform-based, and the emerging research in the stream of digital business model (Markus \& Loebbecke, 2013; Woodard, et al., 2013) is calling companies to consider their IT platform as a key resource of their business model, which supports them not only at department level (Hotho \& Champion, 2011; Andal-Ancion, et al., 2003; Straub \& 
Watson, 2001), but also to shape their digital strategy to create differential value (Bharadwaj, et al., 2013). The platform in our Unicorns plays the key role to enlarge the users base, multiplying the network effects across the internal, external stakeholders, and users, and distribute and communicate the value proposition. Accordingly, the platform is fundamental in the business model of our Unicorns, as it supports them in their business strategy and encompasses different company levels, i.e., product, process, department and corporate (Hess, et al., 2016). Contrary to what most of the innovation management research has considered for years, the IT platform here is no longer limited to a department (or lower) company levels. On this direction, the paper advances also existing knowledge into the research of innovation ecosystems, which finds the technological infrastructure or platform the decisive factor, also in terms of timing, to implement and commercialize new products and services into the market (Adner \& Kapoor, 2010). Indeed, the platform of our Unicorns significantly affects the speed of diffusion of their value proposition and the benefits that can accrue among the technology leaders, internal and external stakeholders, and users. Finally, our study contributes to the lively academic debate around how the role and the balancing of internal and external stakeholders can facilitate innovation of processes and products (Brem \& Viardot, 2015) also in terms of their speed of diffusion into the market. By doing so, we enrich existing theoretical frameworks describing innovation diffusion of products and processes, especially in high-technology and fast-changing markets.

In addition, even though the research is characterized by an exploratory nature and the data collection does not have statistical validity, we have tried to offer some preliminary, quantitative information on the speed of diffusion of our Unicorns resulting from the implementation of the "Larger Partners Ecosystem" and the "Smaller Partners Ecosystem" business model configurations. In addition, our framework needs to be refined and applied to other cases of Unicorns, or similar techcompanies, or to small and micro enterprises, to be enriched and adapted according to the specific contexts. In addition, by enlarging the empirical base, scholars can provide a clearer understanding of the role of peculiar business model design and innovation choices in the creation, management and diffusion of new products and services enabled by digital technologies. Finally, a deepened analysis that involves primary sources of information, such as a high number of key respondents who have collaborated to the creation and commercialization of the Unicorns' innovations, could be conduct in to provide value added to our work. 


\section{REFERENCES}

Afuah, A., and Tucci, C.L. (2001). Internet business models and strategies: Text and cases. New York: Mc-Graw Hill.

Andal-Ancion, A., Cartwright, P., and Yip, G.S. (2003). The digital transformation of traditional business. MIT Sloan Management Review, 44(4), 34-41.

Bannerjee, A., (1992). A simple model of herd behaviour. Quarterly Journal of Economics, 107, 797-817.

Bharadwaj, A., El Sawy, O.A., Pavlou, P.A., Venkatraman, N.V. (2013). Digital business strategy: toward a next generation of insights. MIS Quarterly, 37(2), 471-482.

Bikhchandani, S., Hirschleifer, D., and Welch, I., (1992). A theory of fads, fashion, custom and cultural change as informational cascades. Journal of Political Economy, 100, 992-1026.

Bikhchandani, S., Hirschleifer, D., and Welch, I., (1998). Learning from the behaviour of others: conformity, fads and informational cascades. Journal of Economic Perspectives, 12, 151-170.

Brem, A., and Viardot, É. (2015). Adoption of innovation: Balancing internal and external stakeholders in the marketing of innovation. In Adoption of Innovation (pp. 1-10). Springer, Cham.

Casadesus-Masanell, R., and Zhu, F. (2013). Business model innovation and competitive imitation: the case of sponsorbased business models. Strategic Management Journal, 34, 464-482.

Chesbrough, H. (2007). Business model innovation: it's not just about technology anymore. Strategy \& Leadership, 35(6), 12-17.

Chesbrough, H. (2010). Business Model Innovation: Opportunities and Barriers. Long Range Planning, 43(2-3): 354-363.

Chiesa, V., and Frattini, F. (2011). Commercializing technological innovation: learning from failures in high-tech markets, Journal of Product Innovation Management, 28, 437-454.

Davis, F.D. (1989). Perceived Usefulness, Perceived Ease of Use, and User Acceptance of Information Technology. MIS Quarterly, 13(3), 319-340.

De Massis, A., Frattini, F., and Quillico, F. (2016). What Big Companies Can Learn from the Success of the Unicorns. Harvard Business Review.

De Vany, A., and Walls, W., (1996). Bose-Einstein dynamics and adaptive contracting in the motion picture industry. Economic Journal, 106, 1493-1514.

Downes, L., and Nunes, P. (2013). Big Bang Disruption: Business Survival in the Age of Constant Innovation. New York, USA, Portfolio Penguin.

Foss, N.J., and Saebi, T. (2017). Fifteen years of research on business model innovation: how far have we come, and where should we go? Journal of Management, 43(1), 200-227.

Fritscher, B., and Pigneur, Y. (2009). Supporting business model modelling: A compromise between creativity and constraints. In International Workshop on Task Models and Diagrams for User Interface Design (pp. 28-43). Springer Berlin Heidelberg.

Geroski, P.A. (2000). Models of technology diffusion. Research policy, 29(4), 603-625

Golder, P.N., and Tellis, G.J. (1993). Pioneer advantage: Marketing logic or marketing legend? Journal of Marketing Research, 30(2), 158-170.

Gottschalk, L. R. (1969). Understanding history: A primer of historical method. New York: Knopf.

Hess, T., Matt, C., Benlian, A., and Wiesböck, F. (2016). Options for Formulating a Digital Transformation Strategy. MIS Quarterly Executive, 15(2), 123-139.

Hotho, S., and Champion, K. (2011). Small businesses in the new creative industries: innovation as a people management challenge. Management Decision, 49(1), 29-54.

Ireland, R.D., Hitt, M.A., Camp, S.M., and Sexton, D.L. (2001). Integrating entrepreneurship and strategic management actions to create firm wealth. Academy of Management Executive, 15(1), 49-63.

Joyce, A., and Paquin, R.L. (2016). The triple layered business model canvas: a tool to design more sustainable business models. Journal of Cleaner Production, 135, 1474-1486.

Markides, C.C. (2013). Business model innovation: what can the ambidexterity literature teach us? The Academy of Management Perspectives, 27(4), 313-323. 
Markus, M.L., and Loebbecke, C. (2013). Commoditized digital processes and business community platforms: new opportunities and challenges for digital business strategies. MIS Quarterly, 37(2), 649-654.

Massa, L., Tucci, C., and Afuah, A. (2016). A critical assessment of business model research. Academy of Management Annals, annals-2014.

Meertens, L.O., Iacob, M.E., Nieuwenhuis, L.J., Van Sinderen, M.J., Jonkers, H., and Quartel, D. (2012). Mapping the business model canvas to archimate. In Proceedings of the 27th annual ACM symposium on applied computing (pp. 1694-1701). ACM.

Moore, G.A. (1991). Crossing the chasm. New York, HarperBusiness.

Moreau, F. (2013). The Disruptive Nature of Digitization: The Case of the Recorded Music Industry. International Journal of Arts Management, 15(2).

Muhtaroglu, F.C.P., Demir, S., Obali, M., and Girgin, C. (2013). Business model canvas perspective on big data applications. In Big Data, 2013 IEEE International Conference on (pp. 32-37). IEEE.

Osterwalder, A. (2004). The business model ontology: A proposition in a design science approach.

Osterwalder, A., Pigneur, Y., and Tucci, C.L. (2005). Clarifying business models: Origins, present, and future of the concept. Communications of the AIS, 16(1).

Osterwalder, A., and Pigneur, Y. (2013). Business model generation: a handbook for visionaries, game changers, and challengers. John Wiley \& Sons.

Pagani, M. (2013). Digital business strategy and value creation: Framing the dynamic cycle of control points. MIS Quarterly, 37(2), 617-632.

Pateli, A.G., and Giaglis, G.M. (2005). Technology innovation-induced business model change: a contingency approach. Journal of Organizational Change Management, 18(2), 167-183

Ramadan, A., Lochhead, C., Peterson, D., and Maney, K. (2015). Time to Market Cap: The New Metric That Matters. Play Bigger Advisors, LLC.

Rogers, E.M. (2003). Diffusion of innovations (5th ed.). New York: The Free Press.

Rosenberg, N. (1976). On technological expectations. Economic Journal, 86(343), 523-535.

Ryan, B., and Gross, N. (1943). The diffusion of hybrid seed corn in two Iowa communities. Rural Sociology, 8(1), 1524.

Schilling, M., and Hill, C. (1998). Managing the New Product Development Process: Strategic Imperatives. The Academy of Management Executive, 12(3), 67-81.

Schilling, M. (2005). Strategic management of technological innovation. New York: McGraw-Hill/Irwin.

Schneider, S., and Spieth, P. (2013). Business model innovation: towards an integrated future research agenda. International Journal of Innovation Management, 17(1), 1340001-1-1340001-34.

Schumpeter, J.A. (1961). The theory of economic development: an inquiry into profits, capital, credit, interest, and the business cycle, translated from the German by Redvers Opie, New York: OUP

Spieth, P., Ricart, J.E., and Schneckenberg, D. (2014). Business model innovation - state of the art and future challenges for the field. R\&D Management Journal, 44(3), 237-247.

Straub, D.W., and Watson, R.T. (2001). Research commentary: Transformational issues in researching IS and net-enabled organizations. Information Systems Research, 12(4), 337-345.

Tarde, G. (1903). The Laws of Imitation. Trans. Elsie Clews Parsons. 1st French ed., 1880; 2nd ed., 1885. New York: Henry Holt.

Teece, D. J. (2010). Business models, business strategy and innovation. Long Range Planning, 43(2-3), 172-194.

Trapp, M., Voigt, K.I., and Brem, A. (2018). Business models for corporate innovation management: Introduction of a business model innovation tool for established firms. International Journal of Innovation Management, 22(01), 1850007.

Urbinati, A., Chiaroni, D., and Chiesa, V. (2017). Towards a new taxonomy of circular economy business models. Journal of Cleaner Production, 168, 487-498.

Urbinati, A., Chiaroni, D., Chiesa, V., Franzò, S., and Frattini, F. (2018a). An exploratory analysis on the contextual factors that influence disruptive innovation: the case of Uber. International Journal of Innovation and Technology Management, in press. 
Urbinati, A., Chiaroni, D., Chiesa, V., Franzò, S., and Frattini, F. (2018b). How incumbents manage waves of disruptive innovations: An exploratory analysis of the global music industry. International Journal of Innovation and Technology Management, forthcoming.

Vargas, I.S., Calva, A.L.G., and Camacho, J.H. (2015). Business model canvas. Ciencias Huasteca Boletín Científico de la Escuela Superior de Huejutla, 3(5), 1-6.

Weber, R. P. (1990). Basic content analysis (No. 49). Sage.

Woodard, C.J., Ramasubbu, N., Tschang, F.T., and Sambamurthy, V. (2012). Design capital and design moves: the logic of digital business strategy. MIS Quarterly, 37(2), 537-564.

Zolnowski, A., Weiß, C., and Bohmann, T. (2014). Representing Service Business Models with the Service Business Model Canvas - the Case of a Mobile Payment Service in the Retail Industry. In system sciences (HICSS), 47th Hawaii International Conference on (pp. 718-727). IEEE.

Zott, C., Amit, R., and Massa, L. (2011). The business model: Recent developments and future research. Journal of Management, 37(4), 1019-1042. 


\section{APPENDIX}

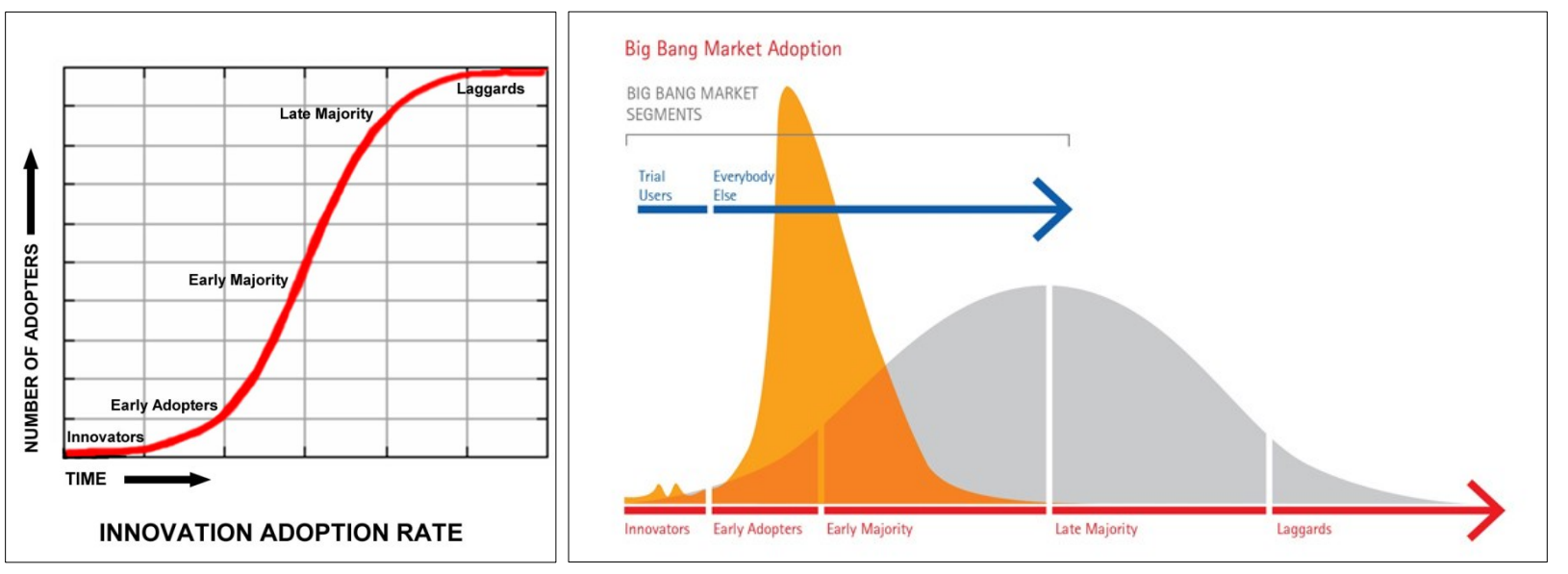

Figure 1A: Traditional business S-curve and the "shark-fin” model (Sources: Rogers, 2003; Downes \& Nunes, 2013).

Table 1A: The business model of the sampled Unicorns.

\begin{tabular}{|c|c|c|}
\hline Unicorn & Business Model Canvas & Description \\
\hline \multirow{3}{*}{ Uber } & Value Network & 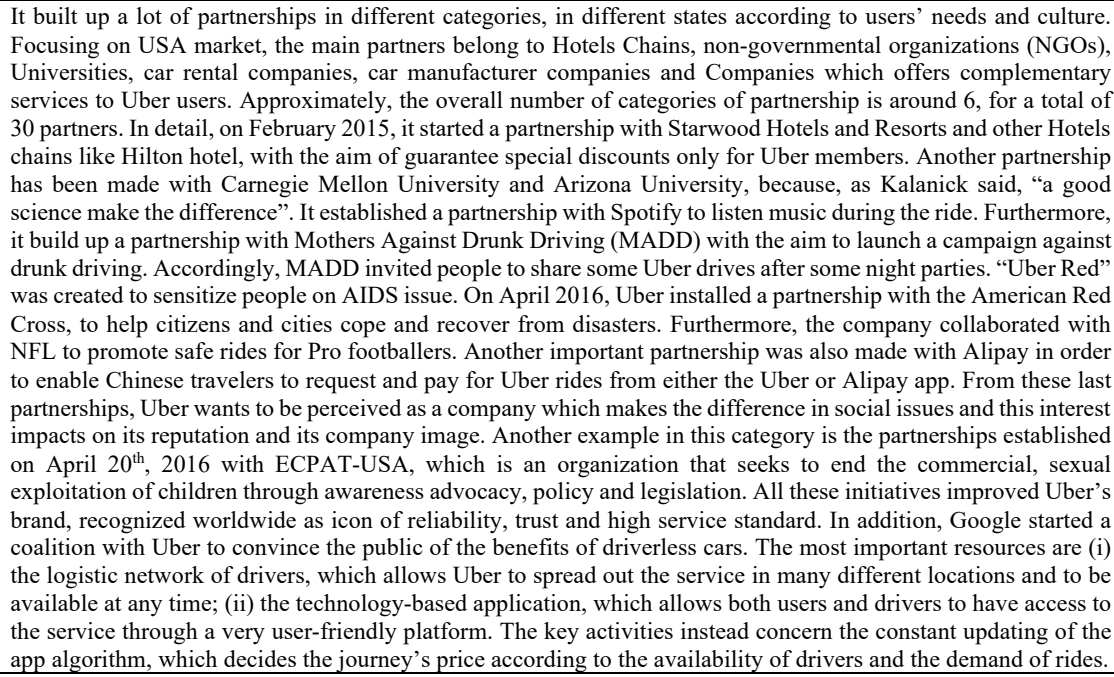 \\
\hline & $\begin{array}{l}\text { Customer Value } \\
\text { Proposition \& Interface }\end{array}$ & 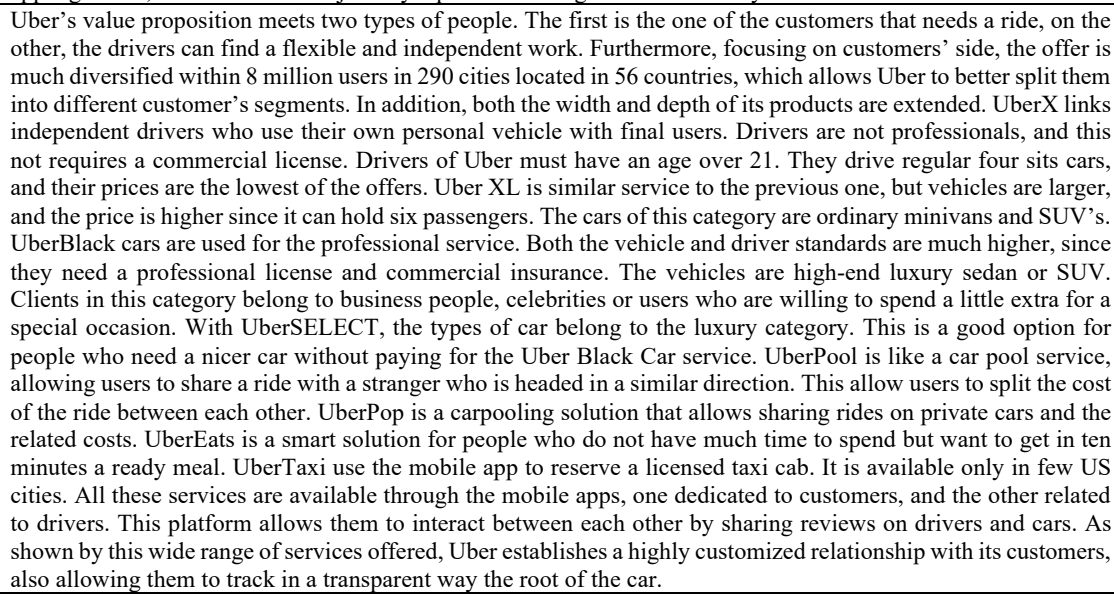 \\
\hline & Economic Model & $\begin{array}{l}\text { The prices are different according to the specific service. Customers pay through the account by using a credit } \\
\text { card, knowing in advance the fare. From users' payment Uber keeps the } 20 \% \text {, and the remaining part is given to } \\
\text { the driver. The business model is highly scalable, since the major cost, which Uber needs to sustain, is the initial } \\
\text { one related to the platform development. This allows the company to leverage on a potential high number of future } \\
\text { users and drivers. }\end{array}$ \\
\hline Xiaomi & Value Network & $\begin{array}{l}\text { The company made partnership with the Indian manufacturer Foxconn on } 2015 \text { in order to have lower production } \\
\text { costs. Furthermore, this partnership allows Xiaomi to produce locally, reduce delivery times and share producing } \\
\text { costs and boost margins. Another partner with the semiconductor company NXP in } 2016 \text {. This was made to }\end{array}$ \\
\hline
\end{tabular}




\begin{tabular}{|c|c|c|}
\hline & & $\begin{array}{l}\text { introduce the next generation of Mi5 NXP's Secure Element and Near Field Communication (NFC) solution, } \\
\text { which help accelerating the adoption of mobile payments in China. Another kind of partners' category are } 3 \text { online } \\
\text { retailers like Flipkart, Amazon and Snapdeal. Furthermore, on July } 2015 \text {, in occasion of launching the MI Note } \\
\text { with a 5.7-inch screen, Xiaomi established a partnership with Uber to sell the product a day before the official } \\
\text { availability on its store. The main resource used by Xiaomi is the network community, which boosts the brand } \\
\text { awareness of the company. On the other hand, the key activity of the company is to look for downstream partners, } \\
\text { such as the retailers that sell the company's products to end users. }\end{array}$ \\
\hline & $\begin{array}{l}\text { Customer Value } \\
\text { Proposition \& Interface }\end{array}$ & $\begin{array}{l}\text { Xiaomi offers a wide range of products between mobile phone, tablets, cloud storage services and smart home } \\
\text { products. By the way, the depth of products range is not expanded at all. The offer focuses only on one kind of } \\
\text { customers, i.e. those interested in technology and with online purchasing attitude. Furthermore, the channels used } \\
\text { by the company are not very diversified: Xiaomi uses only the online channel. As regard to the customer } \\
\text { relationship, the company wants to create a community of MI Fans, which shares opinions and feedbacks on } \\
\text { products. As has been told in one of the communication campaign of the company: "Community driven marketing } \\
\text { is like cooking. It needs a recipe, the right ingredients and a lot of heat. Build your own community of 'MI Fans' } \\
\text { and then watch as they help give life to your brand, with new and unexpected twists on your recipe." }\end{array}$ \\
\hline & Economic Model & $\begin{array}{l}\text { The economic model is based on a cost strategy which allows the company to take advantage against competitors } \\
\text { as regard the cost structure. This intent is shown also in its value chain, since Xiaomi establishes relations with } \\
\text { low cost manufacturers and suppliers. The company sells only online through its own website and the three } \\
\text { retailers Amazon, Flipkart and Snapdeal. }\end{array}$ \\
\hline \multirow[t]{3}{*}{ Airbnb } & Value Network & $\begin{array}{l}\text { The company has a history of partnerships. They are classified in } 4 \text { main areas: (i) serving the public, (ii) building } \\
\text { the brand, (iii) connecting the communities and (iv) saving the environment. Starting from the first one, some } \\
\text { representative examples are: (a) the partnership with ServiceNation for ensuring that AmeriCorps volunteers and } \\
\text { other similar programs enjoy free accommodation while saving their country; (b) the partnership with the } \\
\text { American Red Cross to equips Airbnb with the expertise and the resources to offer free emergency preparedness } \\
\text { training for hosts. As far as the "building the brand" section is concerned, the company collaborated with Music } \\
\text { Dealers, to inspire artists to design an Airbnb-themed song that both embodies the brand and connects the } \\
\text { community, and with American Express, to grant members and participants certain benefits including seamless } \\
\text { sign in, verification and check out, and also loyalty programs. In the "connecting the communities" section, we } \\
\text { can find KLM Airlines that promotes Airbnb accommodation across the flight booking process, as well as Summer } \\
\text { Search that promotes home sharing community that is inclusive of all ages and travel purpose (including teens in } \\
\text { the trying process of planning their futures and pursuing education). The last area, "Saving the environment", } \\
\text { highlights the collaboration of the company with Nest to conserve energy and promote cleaner local environment. } \\
\text { Finally, the company did a partnership with Tesla company to bring home charging stations to Airbnb properties } \\
\text { along the west coast. The most relevant activity is the monitoring of customers' feedbacks on their experiences to } \\
\text { find points of improvements. On the other side, the key resources are related to the high skilled talents who design } \\
\text { and support the technical aspects of the platform. However, the reputation of the company, which is perceived as } \\
\text { reliable, allows the users abroad, to search for a service that makes them feel at home, before looking for another } \\
\text { accommodation. }\end{array}$ \\
\hline & $\begin{array}{l}\text { Customer Value } \\
\text { Proposition \& Interface }\end{array}$ & $\begin{array}{l}\text { The company has } 50 \text { million of users, most them are female users. The diffusion is across } 190 \text { countries in more } \\
\text { than } 34.000 \text { cities. The business model serves two types of people: users and owners. Users subscribe into the } \\
\text { platform to find an accommodation either for holidays or business reasons. The offer is diversified into apartments } \\
\text { options both in terms of depth and width (small, luxury or informal). This implies to have different price segments. } \\
\text { On the other side, we have the owners of the properties, who rent them in a flexible way without constraints in } \\
\text { term of time. Their intent is to build a strong community where each individual feels like at home and "never a } \\
\text { stranger". The users are linked to the company offer through the mobile app and the internet website. }\end{array}$ \\
\hline & Economic Model & $\begin{array}{l}\text { The payment system is based on Airbnb platform. For each transaction, the company adds service (around } 3 \% \text { of } \\
\text { the total amount of the expense) and tax costs, which will be kept by the company. Hosts have to pay on every } \\
\text { completed transaction. Furthermore, travelers have to pay a service fee to Airbnb for an efficient and a } 24 \mathrm{~h} \text { service. }\end{array}$ \\
\hline \multirow[t]{3}{*}{ Palantir } & Value Network & $\begin{array}{l}\text { The company built its network focusing on two types of partners: data partners, who complement customer's } \\
\text { enterprise data and enhance the analysis within the data fusion platform, and service providers, who extend their } \\
\text { reach and meet customer demand for additional services such as customized training and analytical support. For } \\
\text { instance, Tomson Reuters is an example of data partner that offers a specific investigative platform, named } \\
\text { CLEAR, designed for professionals who need the information about people and companies. A Second example is } \\
\text { Dow Jones that serves corporate and financial market clients with financial news and information on products and } \\
\text { services. As regard to the service providers, PVM provides system engineering and software life cycle to support } \\
\text { Palantir deployments. It also provides a quality customer support and innovative solutions for the Palantir } \\
\text { platform. The offer is highly based on technology, which differs in accordance to the service offered. For instance, } \\
\text { as regard to Gotham, the technology supports data storage like Phoenix (that leverages several open source } \\
\text { technology) to manage data at scale and to perform advanced analytics against those data. The key resources are } \\
\text { the technology experts and the high sophisticated tools, which are reliable to manage top-secret information and } \\
\text { data, whereas the key activities are related to the constant monitoring and reinforcement of cyber security practices. }\end{array}$ \\
\hline & $\begin{array}{l}\text { Customer Value } \\
\text { Proposition \& Interface }\end{array}$ & $\begin{array}{l}\text { There are two types of services: Gotham and Metropolis. Gotham allows analyzing enterprise data starting from } \\
\text { data of heterogeneous multiple sources and transforming them into meaningfully defined objects entities. } \\
\text { Metropolis is designed for clients interested in tracking and analyzing insurance claims data, network traffic flow, } \\
\text { and financial trading patterns. Palantir customers belong to both private and public sectors. Palantir and its } \\
\text { customers work together to create customized solutions that improve the outcomes. At the beginning, Palantir was } \\
\text { used by around } 12 \text { groups within the US government including CIA, FBI, Air Force, Marine Corps. For example, } \\
\text { the Pentagon used the software to track patterns in roadside bomb deployment. Samuel Reading, a former marine } \\
\text { who works in Afghanistan said "It's the combination of every analytical tool you could ever dream of. You will } \\
\text { know every single bad guy in your area." The customer relationship is highly customized according to customers' } \\
\text { needs and requirements. However, the width is not large. Users are linked to the company thanks to the website. }\end{array}$ \\
\hline & Economic Model & $\begin{array}{l}\text { The main costs of the company refer to the development of the different platforms and technologies, which are } \\
\text { crucial for its scalable business model. }\end{array}$ \\
\hline \multirow{2}{*}{$\begin{array}{l}\text { Meituan- } \\
\text { Dianping }\end{array}$} & Value Network & $\begin{array}{l}\text { It is the China's largest group deal site, which sells vouchers on local services and entertainment. Partners of the } \\
\text { company are all providers of services and products and can be displayed in the platform. Their displayed offers } \\
\text { are more than } 300 \text {. These partners belong to different industries and supply with their products pubs (i.e. Sing } \\
\text { Song KTV), restaurants (i.e. Mennon Vegetarian Restaurant), hotels, shops, cinemas (i.e. Cloud Melody Movie } \\
\text { Bar), theatres and entertainments (i.e. Pacific Underwater World). They represent effectively the key resources for } \\
\text { the company. Their number is continuously increasing and mainly due to the nature of the service offered, i.e. } \\
\text { higher is the number of sellers, as well as the offering and the traffic, higher is number of customers reached by } \\
\text { the company. }\end{array}$ \\
\hline & $\begin{array}{l}\text { Customer Value } \\
\text { Proposition \& Interface }\end{array}$ & $\begin{array}{l}\text { The customers' segment can be split in two dimensions: the users who want to find the right product at the right } \\
\text { price, and the sellers who want to reach a higher number of end users. For their aim, the former use products' } \\
\text { comparison, which is available due to the large product range in terms of width and depth, whereas the latter } \\
\text { ensure great visibility for their products or services. Customers and sellers meet themselves on the platform thanks } \\
\text { to the internet website and mobile app. Here, they can also write reviews about their previous purchases. The } \\
\text { company has } 150 \text { million of monthly active users, who place about } 10 \text { million orders each day. The customer } \\
\text { relationship is quite standardized, although it can be tailored thanks to the filter availability on the website. }\end{array}$ \\
\hline
\end{tabular}




\begin{tabular}{|c|c|c|}
\hline & Economic Model & Meituan takes from 2 to $3 \%$ on each transaction made by its customers. \\
\hline \multirow[t]{3}{*}{ Snapchat } & Value Network & $\begin{array}{l}\text { Most of Snapchat partners are media companies, such as Hearts and National Geographic, specialized in creating } \\
\text { compelling video and still imagery, i.e. the two key messages that the company trades in. Other partnerships of } \\
\text { Snapchat belong to the sports sector; for instance, Turner Sports started to collaborate with the company on March } \\
2016 \text { with the goal of enhancing fans' storytelling and viewing experiences through Snapchat coverage of major } \\
\text { sporting events. Moreover, the company collaborates with bloggers, such as Christine Andrew with her blog } \\
\text { "Hello Fashion", that aim at promoting their web space and gain visibility. The users represent the main key } \\
\text { resource of the company: the platform works thanks to the connection between people. Another key resource is } \\
\text { represented by the brand reliability, which brings the users to trust the company contents that are displayed for a } \\
\text { small time-lapse and so they cannot be copied. A relevant key activity deals with the management of advertising } \\
\text { contents belonging to many different brands, which use Snapchat as a communication channel. The competitive } \\
\text { advantage perceived by brands through Snapchat, in comparison with other social networks, concerns the } 100 \% \\
\text { of visibility and full screen ads. }\end{array}$ \\
\hline & $\begin{array}{c}\text { Customer Value } \\
\text { Proposition \& Interface }\end{array}$ & $\begin{array}{l}\text { Snapchat is the best way to reach users from } 13 \text { to } 34 \text { years old. More than } 60 \% \text { of US smartphone users are Snap } \\
\text { chatters. The US customer segment is around } 100 \text { million daily and can be clustered in the following groups: } 23 \% \\
\text { between } 13-17 \text { years old; } 37 \% \text { between } 18-24 \text { years old; } 26 \% \text { between } 25-34 \text { years old; and } 12 \% \text { between } 35-54 \\
\text { years old. The customer offer is the same for all the customers and it is not diversified at all, rather, it the customer } \\
\text { relationships is quite standardized. }\end{array}$ \\
\hline & Economic Model & $\begin{array}{l}\text { As far as the revenue streams are concerned, the company receives money from many brands, which want to be } \\
\text { displayed through ads on the Snapchat platform. The "Discover" section allows media publisher to have daily } \\
\text { content featured on the app. Therefore, companies can pay to have themselves featured in the "Stories" section, } \\
\text { where users normally find public snaps from friends and events around the world. The most salient detail in the } \\
\text { cost structure is the storage one, which has been estimated around } \$ 400 \text { million/ year. }\end{array}$ \\
\hline \multirow{3}{*}{ WeWork } & Value Network & $\begin{array}{l}\text { The company has approximately } 200 \text { partners. The main typologies of partners concern (i) web service providers, } \\
\text { such as Amazon Web Services; (ii) health insurance companies, such as New York Health \& Raquet; (iii) hotels, } \\
\text { such as Kimpton Hotels and Restaurants; and (iv) commerce service providers, such as Chase. All of these partners } \\
\text { offer to WeWork members (the users) a special discount rate, together with leisure services and events, such as } \\
\text { gym and sportive areas. The key resource is not tangible, but it is more related to the reputation: the entire } \\
\text { partnership network allows to the company to offer not only the physical space, but also the comfortable } \\
\text { experience, which is connected to the company image. On the other hand, the key activities concern the community } \\
\text { engagement and the location search. }\end{array}$ \\
\hline & $\begin{array}{c}\text { Customer Value } \\
\text { Proposition \& Interface }\end{array}$ & $\begin{array}{l}\text { The service of the company is offered through a mobile app that allows connecting with over } 50.000 \text { members } \\
\text { across the globe; its communication channel is also based on the internet website. Customers are both users who } \\
\text { need space, but also building owners who want to rent their properties in the most rewarding way. The service is } \\
\text { differentiated in two options, which target two different customers' segments: (i) the common membership, for } \\
\text { people who can book workspaces and conference rooms at any location in a very flexible way; and (ii) the full- } \\
\text { time membership, for people who want to assess a dedicated desk and need to work in team. Customers can be } \\
\text { both private or companies. The offer is much diversified, for instance, WeWork provides workspaces, conference } \\
\text { rooms of any size, prices and tailored services. WeWork members belong to an online community, which allow } \\
\text { them to have more than } 250 \text { benefits. An office space at WeWork includes furniture, super-fast internet connection, } \\
\text { printer, scanner and other multifunctional technologies, events planning and invitations, as well as other extras } \\
\text { such as sportive and fun activities, and health insurance coverage. The major benefits are addressed to big } \\
\text { companies, and most of discounts belong to the healthcare services, web-hosted services, gym membership and } \\
\text { travels. }\end{array}$ \\
\hline & Economic Model & $\begin{array}{l}\text { The revenues of the company come from the payment of the specific service users want to benefit. A "hot desk" } \\
\text { solution that includes a desk in a common area, costs around } \$ 220 / \text { mo. A "dedicated desk" service includes a } \\
\text { desk in a shared area where users can leave their belongings. The price for this service is about } \$ 325 / \text { mo. The last } \\
\text { option is the "private office", with which a price of } \$ 450 / \text { mo. Both private and companies can access to a fully } \\
\text { furnished space. In addition, a second source of revenues comes from the monthly fee, which members have to } \\
\text { pay and that is around } \$ 45 / \text { mo. The cost structure is mainly related to the furniture and space maintenance (i.e. } \\
\text { cleaning, internet connection, drinks and food and business class technology). }\end{array}$ \\
\hline \multirow{3}{*}{ Didi Kuaidi } & Value Network & $\begin{array}{l}\text { Didi established partnership with Lyft, Ola, and Grab taxi in order to discourage the usage of Uber, its main } \\
\text { competitor. For instance, Lyft that works in US will hail a car for Chinese visitors, whereas DIDI pull up a ride } \\
\text { for Lyft visitors in China. Other important partnership has been made by the company with (i) WeChat in order to } \\
\text { allow users to share the journey, (ii) Alibaba's Alipay in order to manage the payment system through the app, } \\
\text { and (iii) Tencent Map as far as the cloud service and application development are concerned. The key resource of } \\
\text { the company is related to the logistic network of drivers, which enables Didi Kuaidi to be present everywhere at } \\
\text { every time. One of the key activities deals with the payment management system, which allow money to be } \\
\text { transferred from the user to the driver. }\end{array}$ \\
\hline & $\begin{array}{c}\text { Customer Value } \\
\text { Proposition \& Interface }\end{array}$ & $\begin{array}{l}\text { Didi operates in nearly } 400 \text { cities in China and it has around } 160 \text { million users. The value proposition is split } \\
\text { between users who need a vehicle and drivers who look for a flexible work opportunity according to their } \\
\text { availability of time and resources. All drivers have to pass a comprehensive road test and train up to Kuaidi service } \\
\text { level standard. Their vision is about "to serve each Chinese in each moment". Drivers and customers need to } \\
\text { subscribe in two different kinds of apps. In this way, the company can manage separately the connections with the } \\
\text { two kinds of users and enriches each app with the suited information for them. The user can have access to the } \\
\text { website where are shown all the information about the services offered in a transparent way, and this allow to } \\
\text { build a strong consumer relationship. The customer relationship is customized according to the specific users' } \\
\text { needs, and it mainly involves two options: (i) the Taxi Hailing service, with which passengers send a ride request } \\
\text { through the app and a taxi will pick up them in their location; this service helps taxi drivers to improve their income } \\
\text { by increasing the number of their rides and reducing their idle time, (ii) Didi Hitch, which is a social ride sharing } \\
\text { service that matches drivers and passengers who share similar routes, (iii) Private Cars, which is a private cars } \\
\text { service that connects passengers (with travel needs) and chauffeured cars, and (iv) Designated Driving Service, } \\
\text { which connects drivers with car owners. All the information about the company concern the different typologies } \\
\text { of cars and the tariffs that are shown into the internet website. }\end{array}$ \\
\hline & Economic Model & $\begin{array}{l}\text { Tariffs for users are calculated in a transparent reliable way. The algorithm depends on the type of car, base fare, } \\
\text { kilometers and minutes for the ride. For the standard service the base fair is about } 15 \mathrm{Y}, 2.90 \mathrm{Y} \text { per km and } 0.50 \\
\mathrm{Y} \text { per minute. If we consider a van with } 6 \text { passengers' seats, the fair is about } 25 \mathrm{Y} \text { for the basic one, } 4.90 \mathrm{Y} \text { per } \\
\mathrm{km} \text {, and } 0.84 \mathrm{Y} \text { per minute. The premium version requires a fair of about } 29 \mathrm{Y} \text { for the basic one, } 4.90 \mathrm{Y} \text { per km, } \\
\text { and } 0.99 \mathrm{Y} \text { per minute. }\end{array}$ \\
\hline Flipkart & Value Network & $\begin{array}{l}\text { The service consists of a partnership network composed by the main sellers of products available in the platform. } \\
\text { For instance, the largest one involves big companies, such as Motorola, Xiaomi, Huawei, operating the electronic } \\
\text { industry. The management of the order confirmation, as well as all the activities involved from the acceptance } \\
\text { until the reception one, are the key activities of Flipkart. On the other way, the key resource of the company is the } \\
\text { platform, based on an intuitive interface, which requires only few steps for users to buy the products. }\end{array}$ \\
\hline
\end{tabular}




\begin{tabular}{|c|c|c|}
\hline & $\begin{array}{c}\text { Customer Value } \\
\text { Proposition \& Interface }\end{array}$ & $\begin{array}{l}\text { The value proposition can be divided in two main side: (i) the first one is represented by users (around } 22 \text { million), } \\
\text { who find a product in a short time and deliver it in few days; (ii) the second one is composed by sellers who want } \\
\text { to sell their products gaining visibility. The offer is shown through the internet website of the company, which is } \\
\text { split into several categories: electronics, men, women, baby\&kids, home\&furniture, books\&media, auto\&sports. } \\
\text { The customer relationship is quite standardized; indeed, the range of products is limited to the choices visible on } \\
\text { the platform. Nevertheless, it can be customized according to the available options on the website. Customers can } \\
\text { benefit also of additional services such as the order tracking, free and easy returns, online cancellation and loyalty } \\
\text { programs. }\end{array}$ \\
\hline & Economic Model & $\begin{array}{l}\text { The revenue streams come from the marketplace fee paid by sellers, which includes the shipping fee (calculated } \\
\text { based on the product weight and the shipping location), the fixed closing fee (a small fee that Flipkart charges on } \\
\text { all the transactions), the selling commission and a service tax (\% on selling prices that depends on product } \\
\text { categories). One of the main costs is related to the Search Engine Marketing activities, which consists in buying } \\
\text { strategic keywords to gain traffic through the browser. }\end{array}$ \\
\hline \multirow[t]{3}{*}{ SpaceX } & Value Network & $\begin{array}{l}\text { The company did a partnership with the Kennedy Space Centre of NASA in 2010, to create technologies that fit } \\
\text { the needs of the company. Furthermore, another important partner is Google, with which the company is trying to } \\
\text { bring Internet to the most remote places of the Earth (and Mars), by using satellites. The number of partners is } \\
\text { very limited due to the nature of the products offered, mainly addressed to very limited technical scopes and } \\
\text { missions. The main resources are represented by the high skilled profiles of its engineers and technicians, as well } \\
\text { as by the knowledge that is developed over time. The key activities are related to the management of interactions } \\
\text { with clients to decide the assembly phases and the technical parts of the final products. }\end{array}$ \\
\hline & $\begin{array}{c}\text { Customer Value } \\
\text { Proposition \& Interface }\end{array}$ & $\begin{array}{l}\text { The product range is quite limited. Advanced rockets, spacecraft and satellites mainly compose the offer of } \\
\text { SpaceX. However, these products, and so the customer relationship, are customized according to the specific } \\
\text { missions of NASA, and they can be summarized in three types: Falcon 9, Falcon Heavy, and Dragon. The channel } \\
\text { used by the company is primarily the direct relationship with NASA managers and the website. }\end{array}$ \\
\hline & Economic Model & $\begin{array}{l}\text { Prices of Space-X products are around } \$ 61.2 \mathrm{M} \text { (For falcon } 9 \text { ) in the standard version, and } \$ 90 \mathrm{M} \text { (for Falcon } \\
\text { Heavy). The main costs are related to the testing phase of its products and } \mathrm{R} \& \mathrm{D} \text { for future discoveries. }\end{array}$ \\
\hline \multirow[t]{3}{*}{ Pinterest } & Value Network & 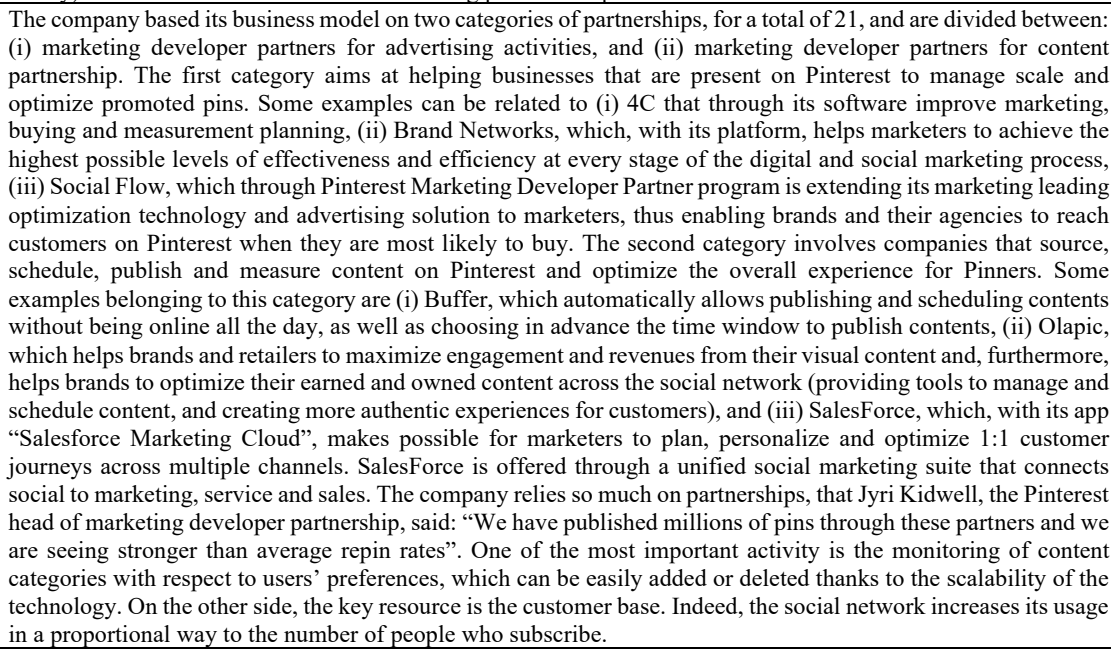 \\
\hline & $\begin{array}{c}\text { Customer Value } \\
\text { Proposition \& Interface }\end{array}$ & $\begin{array}{l}\text { The value proposition can be split in two dimensions: (i) users who want to share and follow contents related to } \\
\text { their personal interests; (ii) business companies that want to optimize their effort from a marketing point of view. } \\
\text { Users can share their own wide interests with a community of people personally chosen and can share their results } \\
\text { on other social networks. The customer segment is made of } 176 \text { million registered users, usually aged between } 25 \\
\text { and } 44,20 \% \text { male and } 80 \% \text { female. The major categories of interest are food, fashion, sport, beauty, makeup and } \\
\text { travels. }\end{array}$ \\
\hline & Economic Model & $\begin{array}{l}\text { The revenue streams block is mainly characterized by money received from companies, which use this social } \\
\text { network for marketing purposes. The major cost is the one of the content monitoring and platform updating. }\end{array}$ \\
\hline \multirow[t]{3}{*}{ Dropbox } & Value Network & $\begin{array}{l}\text { The main categories of partners are device manufacturers, network providers, developers and retailers, with a } \\
\text { passion for action-oriented analytics, who want to create a win-win solution with the company. The total number } \\
\text { of partnerships is 5. Some examples of these relationships are those with (i) Microsoft, to provide Dropbox users } \\
\text { the benefits related to the usage of Office across desktop, mobile and web. Microsoft's Productivity Suite will } \\
\text { soon become the standard way to edit Microsoft office files stored on Dropbox storage, (ii) Samsung, which } \\
\text { provides Dropbox users the right instruments to benefit of additional storage space and more safety space for their } \\
\text { memories, and (iii) Avira. Accordingly, the Head of Strategic Partnerships at Dropbox, Tom Hsieh said: "We are } \\
\text { excited to partner with Avira, to bring Dropbox to more people around the world. Dropbox and Avira are grate } \\
\text { complements in giving users peace of mind and keeping their most important stuff safe. Through this partnership, } \\
\text { we will give Avira's growing user base the ability to use Dropbox to easily access and share their information". } \\
\text { The brand image represents the key resource of the company; indeed, it allows users to perceive the company as } \\
\text { reliable and to share private documents of other users with a high degree of confidentiality. Accordingly, the data } \\
\text { management of users represents another crucial activity of Dropbox. }\end{array}$ \\
\hline & $\begin{array}{c}\text { Customer Value } \\
\text { Proposition \& Interface }\end{array}$ & $\begin{array}{l}\text { The customer relationship is customized according to the space storage needs. Accordingly, } 3 \text { versions of the } \\
\text { products are available: the free version, the pro version, and the business version. However, users do not have the } \\
\text { possibility to choose among different kinds of services, because the cloud storage service is the only one provided. } \\
\text { Users have the possibility to share file and have access to the cloud storage service from any computer or internet } \\
\text { base device. The total number of users is around } 400 \text { million. They are generally divided between students and } \\
\text { professionals. }\end{array}$ \\
\hline & Economic Model & $\begin{array}{l}\text { The model used by the company is Freemium: users can access } 1 \mathrm{~GB} \text { free, and then, if they want to have more } \\
\text { space available, they need to pay. The pro version costs } \$ 99 / \text { year, whereas the Business version costs } \$ 795 / \text { year. } \\
\text { The business model is highly scalable. The major cost of the company was related to the platform development, } \\
\text { whereas the improvement of the platform functionalities can be sustained in a cheap way. }\end{array}$ \\
\hline Lufax & Value Network & $\begin{array}{l}\text { The partnership with Ping An, which is the largest non-state-owned lender in China, allowed the initial goal of the } \\
\text { company: "More banks, insurance companies and other third-party financial institutions are looking to develop } \\
\text { partnerships with Lufax" (Gregory Gibb, CEO of Lufax). The company relies on big data management and IT } \\
\text { latest technology, which both represent key resources and give to the company a competitive edge hard to be } \\
\text { replicated. Due to the nature of the service offered, a key activity is the constant implementation of a security } \\
\text { procedure. }\end{array}$ \\
\hline
\end{tabular}




\begin{tabular}{|c|c|c|}
\hline & $\begin{array}{l}\text { Customer Value } \\
\text { Proposition \& Interface }\end{array}$ & $\begin{array}{l}\text { The value proposition satisfies the necessity of two typologies of actors: the borrower and the lender, which are } \\
\text { both registered customers on Lufax platform. The platform can meet demand and supply. The company offers to } \\
\text { borrower a wide range of ways to access liquidity, and on the other side a wide range of possible favorable } \\
\text { investments, providing credit to small firms and consumers that the state-owned banks have traditionally balked } \\
\text { at servicing. The overall registered users in Lufax platform surpassed } 10 \text { million and the number of transaction } \\
\text { processed grew more than } 8 \text { times every year. The service is offered on the platform, and its main options are } \\
\text { divided between offline (credit screening, risk monitoring, and ratings) and online (online signing, auctions and } \\
\text { loyalty programs) services. }\end{array}$ \\
\hline & Economic Model & $\begin{array}{l}\text { The platform makes money by matching borrowers with investors, collecting a } 4 \% \text { fee on each loan. Furthermore, } \\
\text { the strategy adopted by Lufax is the cost policy, which try to reduce the price of } 0,2-0,5 \% \text { less than competitors. } \\
\text { Payments to Lufax consist of different fees depending on the client category, i.e. the fee payment from market } \\
\text { institutions and retail customers that want to create liquidity for non-standard assets is around } 0,5-5 \% \text { for each } \\
\text { transaction in return; fee payment from the wholesalers is about } 5-20 \% \text { for each product; payment fee for asset } \\
\text { underwriting is about } 5-200 \% \text {. }\end{array}$ \\
\hline \multirow{3}{*}{ Theranos } & Value Network & $\begin{array}{l}\text { As stated in the company's website the } 2 \text { main partnerships established have been those with the pharmaceutical } \\
\text { companies Walgreens and Cleveland Clinic, non-profit academic medical centers, which provide clinical and } \\
\text { hospital care and research, education and health information. They develop their own analysis and treatment in } \\
\text { Theranos Wellness Centre, which represents a key resource together with the high level of technology } \\
\text { implemented in order to conduct all the activities (such as doctors' relationships management and samples } \\
\text { analysis) in the most efficient way. }\end{array}$ \\
\hline & $\begin{array}{l}\text { Customer Value } \\
\text { Proposition \& Interface }\end{array}$ & $\begin{array}{l}\text { Mission of Theranos is to make information accessible to everyone at the time it matters. Patients are the owners } \\
\text { of their own health data and the results of their exams are private, secure and confidential since they are the only } \\
\text { people who manage consumer data. Data are visible through the mobile app, where it is possible to track changes } \\
\text { over time and receive some personal suggestions from doctors and specialist. In choosing the service, different } \\
\text { range of prices are displayed in the website, and this allows patients to know their expenses in advance. Services } \\
\text { are accessible to everyone, and no kind of insurance is required. The total number of tests performed in one year } \\
\text { is approximately around } 6 \text { million and they can be realized on every kind of person. Furthermore, customers can } \\
\text { leave a review about their treatment (today the total number of reviews left are around 30.000). }\end{array}$ \\
\hline & Economic Model & $\begin{array}{l}\text { Consumers can pay for the visit in-store. Theranos Wellness Centers currently accept cash, check and credit cards. } \\
\text { The company wants to bring more payment options both in-store and online in the future. The costs are mainly } \\
\text { related to the development and the maintenance of the technology, which are implemented in the company centers. }\end{array}$ \\
\hline \multirow{3}{*}{ Spotify } & Value Network & $\begin{array}{l}\text { The partners of the company are 27, and they belong to four main categories. The media and festival category } \\
\text { gives visibility to magazines, newspapers, event festivals or radio stations. The Quietus, which is one of the } \\
\text { alternative music world's most influential online magazine, provides a useful example. Thanks to the partnership } \\
\text { with Spotify, Quietus can share the music that discovers and stirs debate about its merits. E4, a TV channel that } \\
\text { attracts the largest youth TV audience in the UK, is another example belonging to this category. Partners of Spotify } \\
\text { engage and grow their audience across the digital channel of the company. Audio hardware are the second category } \\
\text { of partnerships established by Spotify. Here we can find Amazon, LG, Philips, Panasonic and other electronic } \\
\text { industry retailers. The third category of partners is the one of gift card retailers, which generate repeat purchases } \\
\text { of monthly subscriptions, increasing footfall, supplied as physical gift cards and increase availability worldwide. } \\
\text { Walmart, Safeway and Eleven belong to this category. The last one concerns the non-for-profit-organizations that } \\
\text { use music to connect with audience and give energy to social action campaign. The main activities are related to } \\
\text { the management of the relationship with artists and brands, which ask to be sponsored on the platform. While the } \\
\text { key resource is the technology behind the database which is able to support the big data collection and storage } \\
\text { both from a user data perspective and songs portfolio. }\end{array}$ \\
\hline & $\begin{array}{l}\text { Customer Value } \\
\text { Proposition \& Interface }\end{array}$ & $\begin{array}{l}\text { The value proposition is divided between two categories of users, (i) users who want to listen music and follow } \\
\text { their favorite artists, and (ii) artists who can gain international visibility thanks to the platform. The customer } \\
\text { relationship is customized, and the value proposition is highly diversified both in depth (many albums of a same } \\
\text { artist) and in width (many artists for a same musical category), indeed users can choose the singer and the related } \\
\text { album among different options. Furthermore, users can create their own playlist and share it with their friends. } \\
\text { The customer segment, composed by } 75 \text { million of people of } 58 \text { different countries, is very heterogeneous, and } \\
\text { every type of music can be chosen according to personal tastes and needs. }\end{array}$ \\
\hline & Economic Model & $\begin{array}{l}\text { The economic model is a freemium one. Users have the standard version free, or they can choose to pay for the } \\
\text { Premium one } 9.99 € / \text { month. Furthermore, an algorithm characterizing the economic model of the company } \\
\text { explains the royalty system in detail. The artist pay-out is made by the multiplication of these four elements: } \\
\text { Spotify monthly revenues; the ratio between artist's Spotify streams and the total Spotify streams; the } 70 \% \text { of } \\
\text { Spotify gross revenues to master and publishing owners; the artists royal rate. In detail, the first element represents } \\
\text { the revenues made by Spotify in a given month from advertising and subscriptions. The second one is based on } \\
\text { artists' popularity and it can be considered as the "market share" of artists themselves. The third one is due to a } \\
\text { negotiation with labels and publishers in each territory. The last one represents the money paid by Spotify } \\
\text { depending on the contractual agreement with the artist. }\end{array}$ \\
\hline \multirow[t]{3}{*}{ DJI } & Value Network & $\begin{array}{l}\text { The total number of partners in this community is around 550. DJI and the European Emergency Number } \\
\text { Association announced the partnership on April } 2016 \text { and the initiative calls for the selection of European drone } \\
\text { pilot teams to train with Phantom and Inspire drones to optimize emergency response. Furthermore, the company } \\
\text { collaborated with Apple in order to integrate Phantom drones with Apple's iOS ecosystem allowing users to view } \\
\text { and even control their drones via iPad or iPhone. Another example of partnership established by DJI is the one } \\
\text { with Hasselblad, a market leader in high quality professional cameras. The partnership allows opportunities and } \\
\text { new ways of combining the technical knowledge and the inventive spirits of the two industry leaders in their } \\
\text { respective fields. Moreover, IFSC is another example of partnership with the goal to produce aerial imaging at } \\
\text { several of its international events like the IFSC's worlds cup. Furthermore, Youku Tudou, a video sight backed by } \\
\text { e-commerce titan Alibaba Group Holding. Collaborated with DJI to establish a new website channel that shows } \\
\text { aerial video taken with DJI drones. The company collaborated in } 2013 \text { with Shapeways in order to enable the 3D } \\
\text { printing community and to bring accessory for drones to life. In addition, in } 2015 \text {, with Accel, as stated in the } \\
\text { website: "We aim to ignite the platform for thousands of developers and entrepreneurs to take advantage of the } \\
\text { latest in aerial robotics and built for multiple industrial use cases and vertical up categories". The company in } \\
\text { order to enhance creators' creativity built a vibrant online community, where people can share opinions and way } \\
\text { of doing in this field, and this represents a key resource for the company. Due to the nature of the products that } \\
\text { are offered, a crucial key activity is the R\&D. }\end{array}$ \\
\hline & $\begin{array}{l}\text { Customer Value } \\
\text { Proposition \& Interface }\end{array}$ & $\begin{array}{l}\text { The value proposition of the company is single-sided, they produce for the final consumer commercial and } \\
\text { recreational unmanned aerial system that are visionary intelligence. The product width and depth are very } \\
\text { expanded, there are around } 6 \text { different versions of the same product model. The customer relationship is } \\
\text { standardized because they propose their products through the website, where users can buy drones online, and the } \\
\text { customers cannot customize them. The company sold approximately } 416,000 \text { drones in } 2014 \text {. }\end{array}$ \\
\hline & Economic Model & $\begin{array}{l}\text { The company is the largest world consumer drone with an estimation of the global market share around } 70 \% \text {. The } \\
\text { drones' price range is much diversified, and it depends on the technical features of products. Consider for instance } \\
\text { the category of drones; the price range goes from the highest one of } € 5.000,00 \text { to the cheapest of } € 1.100,00 \text {. } \\
\text { Moreover, DJI built a University inside the company with the aim to foster creativity and keep knowledge } \\
\text { internally. This represents the big amount on the total R\&D costs. }\end{array}$ \\
\hline
\end{tabular}




\begin{tabular}{|c|c|c|}
\hline \multirow{3}{*}{ Zhong An Online } & Value Network & $\begin{array}{l}\text { The company was born through the partnership between three big companies: Alibaba, Tencent and Ping An. } \\
\text { Through this cross-industry partnership, Alibaba and Tencent are trying to leverage their user base with the help } \\
\text { of Ping An, to grow into traditional industries. This is the reason why the company has a big portfolio of partners } \\
\text { because it encompasses all the partners of these three actors. Other examples of partners are Baidu, Airbnb and } \\
\text { Zhaopin Limited, a leading career platform in China focusing on connecting users with relevant job opportunities } \\
\text { throughout their career lifecycle. The cooperation with Zhaopin was made to jointly provide internet-financing } \\
\text { services to university graduates and white-collar employees. The overall number of partners is about } 100 \text {. The key } \\
\text { resource of the company is the technology, which is behind all the services provided. One of the key activities of } \\
\text { the company consists in managing customers' data to be able to offer a customized service in line with the clients' } \\
\text { profile. }\end{array}$ \\
\hline & $\begin{array}{l}\text { Customer Value } \\
\text { Proposition \& Interface }\end{array}$ & $\begin{array}{l}\text { Zhong An Online is an insurer that operates completely online. The vision of the company is "aimed at extending } \\
\text { its disrupting approach to an increasing part of the traditional insurance company". The business started from } \\
\text { innovative insurances particularly for ecommerce, such as insurance for transportation costs of returned products } \\
\text { or for deposit. Today the company has a diversified portfolio of about } 200 \text { products grouped in these main } \\
\text { categories: wealth, credit, transportation, and liability, insurance for companies directly involved in ecommerce, } \\
\text { short-term health insurance, auto insurance (including the obligated insurance), and reinsurance of the above- } \\
\text { described insurances. The offer of the company addresses these kinds of actors: insurers and both private } \\
\text { customers and enterprise customers. The benefits of the insurer are related to the cross-industry collaboration that } \\
\text { benefits from the competitive position of participants companies, low fixed costs and high scalable business model. }\end{array}$ \\
\hline & Economic Model & $\begin{array}{l}\text { The revenue streams of the company can be simplified in the sum of the earned premium and investment income } \\
\text { on premiums after underwriting costs and claim expenses. }\end{array}$ \\
\hline \multirow{3}{*}{ UberChina } & Value Network & $\begin{array}{l}\text { Uber China made partnership with Alipay in 2014. Now, the duo is tapping into the huge market for Chinese } \\
\text { tourism and business travels. Initially the partnership started in Hong Kong, Macau and Taiwan - the tree main } \\
\text { hotspots for travelling during the upcoming Chinese New Year - although UberChina said, the agreement "will } \\
\text { be extended to more regions around the world during the year". Moreover, Uber has landed a new partnership with } \\
\text { Guangzhou Automobile Group; the web services provider Baidu in 2015; and additionally, with HNA in order to } \\
\text { enter in Chinese huge tourism industry by introducing an array transportation service from airports to HNA flights, } \\
\text { as well as an online financing for the automotive sector. The company takes also advantage from the numerous } \\
\text { partnerships made by Uber. The key resources and activities are comparable with the traditional Uber service } \\
\text { available in US, with the only difference in the logistic network that is adapted to the Chinese geographic scenario. }\end{array}$ \\
\hline & $\begin{array}{l}\text { Customer Value } \\
\text { Proposition \& Interface }\end{array}$ & $\begin{array}{l}\text { UberChina value proposition is aligned with that of Uber, and for this reason, it addresses two types of users: (i) } \\
\text { passengers that need a ride, and drivers that provide the service. The total number of rides between the summer of } \\
2014 \text { and January } 2016 \text { is around } 1 \text { million. The company operates in } 31 \text { cities in East Asia. The service offered } \\
\text { by the company is diversified according to the peculiarities of the cities. For instance, services offered in Shanghai } \\
\text { are UberX, UberXL, Uberenglish and UberBlack. Uberenglish is a new service, which is available only in China, } \\
\text { in those places where drivers can speak English. This service is not offered in any other city in East Asian market, } \\
\text { since Shanghai is the main business city where English language is widely spoken. }\end{array}$ \\
\hline & Economic Model & $\begin{array}{l}\text { The tariffs are the same applied by the company in the traditional model, i.e. Uber keeps the } 20 \% \text { in each payment, } \\
\text { whereas the remaining part is for drivers. }\end{array}$ \\
\hline \multirow[t]{3}{*}{ Lyft } & Value Network & $\begin{array}{l}\text { Partners of Lyft are split between nationals and locals. In 2016, Lyft collaborated with General Motors and together } \\
\text { the two companies are developing self-driving, as a future challenge. Moreover, another significant partnership } \\
\text { that the company realized was with MLB.com (an exclusive ride sharing partner of the company) to help million } \\
\text { fans to find a safe reliable driving choice. In addition, those with MasterCard, with which the company established } \\
\text { the Priceless Surprises campaign to create surprising and delightful experiences; and with Bay to Breakers to share } \\
\text { free rides with participants and make race day transportation easier. Lyft announced a partnership also with the } \\
\text { National Med Trans Network for providing to seniors in NYC a simpler way to get rides to non-emergency medical } \\
\text { appointments. Furthermore, the company established a partnership with Waze to give drivers all the benefits } \\
\text { related to the implementation of Waze system during their route. For instance, the driver can avoid traffic } \\
\text { congestion thanks to this application. Furthermore, from the company's website, it emerged that other important } \\
\text { partners are Facebook, Slack and Starbucks. Lyft relies on a strong brand identity thanks to branding and } \\
\text { communication activities that allow the company to take a specific place in customers' mind. For instance, the } \\
\text { vehicles are accessorized with large and bright pink mustache attached to the cars' front grille. }\end{array}$ \\
\hline & $\begin{array}{l}\text { Customer Value } \\
\text { Proposition \& Interface }\end{array}$ & $\begin{array}{l}\text { The value proposition of the company splits between users and drivers. The offer of the company is quite } \\
\text { diversified according to customers' needs. Accordingly, (i) Lyft Traditional allows passengers to be connected } \\
\text { and transported by a driver in the nearby (usually alone users) through the usage of the app; (ii) Lyft Line, through } \\
\text { which users share rides along shared routes; and (iii) Lyft Plus, which is available for customers who usually travel } \\
\text { with 5-6 friends planning this in advance. The total number of registered users is about } 100.000 \text {. The total number } \\
\text { of drivers is approximately } 100.000 \text {. }\end{array}$ \\
\hline & Economic Model & $\begin{array}{l}\text { The Lyft fare cost is shown in a transparent way in the website where the user can set his starting point and } \\
\text { destination. The relative price of the journey is displayed for each line of service. In particular, the user has the } \\
\text { opportunity to compare Lyft rates with Uber's ones directly from the website. Additionally, the company has a } \\
\text { number of costs associated with the running of the business, including credit card processing fees, insurance, and } \\
\text { taxes. }\end{array}$ \\
\hline \multirow[b]{2}{*}{ Stripe } & Value Network & $\begin{array}{l}\text { Stripe collaborates with Intuit, an accounting and tax software company for small businesses and self-employed, } \\
\text { to help on-demand workers to keep track of their finances. Stripe established partnership with Twitter, Pinterest } \\
\text { and Facebook to power the payments made through these social networks. Furthermore, the company started to } \\
\text { collaborate with (i) Freshbooks, which creates small business accounting software in the cloud; (ii) GoDaddy, } \\
\text { which is a publicly traded Internet domain registrar and web hosting company; (iii) OpenTable Volusion, which } \\
\text { through enables a quick and easy method to accept international debit and credit cards; and finally with (iv) Xero, } \\
\text { which is a software to manage invoicing, bank reconciliation, bookkeeping. The main resource is the API } \\
\text { technology, which is a set of routines, protocols, and tools for building software and applications and can be easily } \\
\text { integrated with the ERP system already implemented by the company. This is also compatible with most of the } \\
\text { worldwide payment systems. The most important activity relates to the security issue. Indeed, Stripe works to } \\
\text { protect businesses of its clients from fraudulent charges and monitors suspicious transactions. }\end{array}$ \\
\hline & $\begin{array}{c}\text { Customer Value } \\
\text { Proposition \& Interface }\end{array}$ & $\begin{array}{l}\text { The vision of the company is to create a set of unified APIs and tools that instantaneously enable businesses to } \\
\text { accept and manage online payments. The company provides different services through its website. The payment } \\
\text { is available through tablet and mobile devices, which allow the customers to pay instantaneously. The main service } \\
\text { options are: (i) Subscriptions, which allow to get customers information and give toolkit to reach new users; (ii) } \\
\text { Rely, which allows mobile payments through mobile apps; (iii) Connect, through which users can let sellers around } \\
\text { the world get paid; (iv) Bitcoin, which allow to add bitcoin to the payment flow; and (v) Atlas, in order to let } \\
\text { entrepreneurs to easily incorporate a US company to setup a US bank account and to start accepting payment with } \\
\text { Stripe. Atlas is available for developers and entrepreneurs globally. However, these options are quite standardized, } \\
\text { implying an offer to customers not much diversified. The consumer target is made of businesses of any size that } \\
\text { have to develop a market place with a payment system included. The website also includes a review section made } \\
\text { by customers' pictures and feedbacks on their experiences using this service. It was hypothesized that the company } \\
\text { has around } 1.5 \text { bn of transactions, but the company belied this, and the actual number could be doubled. }\end{array}$ \\
\hline
\end{tabular}




\begin{tabular}{|c|c|c|}
\hline & Economic Model & $\begin{array}{l}\text { The company gains payment from customers only for what they use in the form of percentage in the transaction } \\
\text { and fixed tax, i.e. around } 1.4 \%+0.25 € \text { for European card and } 29 \%+0.25 € \text { for non-European card. The main } \\
\text { costs are related to the implementation of a cyber-security system. }\end{array}$ \\
\hline \multirow{3}{*}{$\begin{array}{l}\text { OLA Cabs (ANI } \\
\text { Technologies) }\end{array}$} & Value Network & $\begin{array}{l}\text { OLA has made an exclusive partnership with OnePlus to let customers experience the company's latest } \\
\text { smartphone; and additionally, with the State Bank of India (SBI) to provide easier loans to cab drivers. } \\
\text { Furthermore, the company started to collaborate with Nissan Motor India to establish a cab-leasing program for } \\
\text { driver-partners. Moreover, OLA established a partnership with the customer based service company Haptik, with } \\
\text { the aim to allow users to book OLA Cabs to instant messaging on the app. Finally, with MapMyIndia, OLA } \\
\text { provides an accurate map for India. The key resource of the company is represented by the drivers' network, which } \\
\text { allows a wide availability of cabs. On the other side, the main activity of the company deals with the management } \\
\text { of the incentives and commission system of drivers themselves. }\end{array}$ \\
\hline & $\begin{array}{l}\text { Customer Value } \\
\text { Proposition \& Interface }\end{array}$ & $\begin{array}{l}\text { The value proposition of the company is addressed to two main actors: (i) users who need a ride, and (ii) drivers } \\
\text { who provide the service by having a flexible job solution. The total number of drivers is around } 200.000 \text { across } \\
85 \text { cities. The company has about } 150.000 \text { bookings per day and gains both the } 60 \% \text { of Indian market share and } \\
\text { the } 80 \% \text { of Indian taxi market share. Services offered by OLA are customized, and so it is the customer } \\
\text { relationship, and this mainly depends on drivers' availability and customers' requests. Accordingly, the company } \\
\text { offers: (i) Ola Shuttle, through which the company plans to launch } 500 \text { shuttles on } 100 \text { routes in Gurgaon and } \\
\text { Bangalore, targeting in this service people who would otherwise drive their vehicles to work; (ii) Ola Money, } \\
\text { which is an online wallet; (iii) Ola Corporate that is addressed to enterprises, which can choose this service for its } \\
\text { business travels; (iv) Taxiforsure, through which users can book the nearest car; and (v) Local taxi, through which } \\
\text { users can book an auto in only few cities. }\end{array}$ \\
\hline & Economic Model & $\begin{array}{l}\text { In addition to the revenues coming from the rides, there are two types of charges: (i) the peak time surcharge, } \\
\text { which is applied during the peak hours, and is conveyed during the booking; and (ii) the service tax. The most } \\
\text { relevant costs are related to the activities of marketing, branding and promotion deals. }\end{array}$ \\
\hline \multirow[t]{3}{*}{ Snapdeal } & Value Network & $\begin{array}{l}\text { The company collaborates with IIT Delhi and with Felix MedicalSolution to sell smartcane online. Smartcane is } \\
\text { an advanced version of the white cane used by visually impaired people and ensures independent mobility and } \\
\text { safety of users. Those partnerships allow potential donors to choose where donate smartcane via Snapdeal } \\
\text { Sunshine platform, through which the product is shipped directly to non-governmental organization (NGOs) } \\
\text { partner Saksham that works for empowering people with blindness. Another partner of Snapdeal is Pantaloons, } \\
\text { with which the company sells its products online and Pantaloons itself can take advantage of the online } \\
\text { marketplace' wide customer base and of operational capabilities. On the other hand, the partnership with Polaris } \\
\text { ensures selling their off-road and commercial vehicles exclusively online. Furthermore, JLL India started to } \\
\text { collaborate with Snapdeal, in } 2016 \text {, to commercialize residential properties online. Snapdeal started to collaborate } \\
\text { additionally with TVS Motor Company, as said by the company in a statement: "on Snapdeal motor platform, } \\
\text { customers will be able to select a model, color and dealership of their choice". The partnership with Zomato allows } \\
\text { the company to enable customers ordering food online through the Snapdeal app. Shopper Stops started to } \\
\text { collaborate with Snapdeal to enhance customer experience in digital marketplace. In order to allow customers } \\
\text { having a rewarding shopping experience, Snapdeal established additionally a partnership with Payback to create } \\
\text { an integrate system to collect loyalty points. The total number of sellers is about } 150,000 \text {. One of the key activities } \\
\text { of the company consists in managing the supply chain network of the company. On the other side, the key resource } \\
\text { is represented by the logistic platform, which requires mandatory subscription for partners. }\end{array}$ \\
\hline & $\begin{array}{l}\text { Customer Value } \\
\text { Proposition \& Interface }\end{array}$ & $\begin{array}{l}\text { The value proposition is split between: (i) customers who can find the right product that fits better their } \\
\text { expectations in terms of price and quality, and (ii) sellers who can gain visibility and increase their customer base. } \\
\text { In particular, the final user can benefit of a larger offer thanks to cross selling actions made by the platform, and } \\
\text { so the user can have access to a really customized offer. The system displays a lot of different categories of } \\
\text { products with a wide choice for customers. The total number of users is about } 25 \text { million; the company operates } \\
\text { in } 5.000+\text { cities and sells more than } 30 \text { million of products belonging to more } 800 \text { different categories from over } \\
125 \text { regional, national and international brands. Furthermore, the customers' segment is composed by people with } \\
\text { interests in electronics, fashion, home design and furniture, sports, motors, real estate and reading. The platform } \\
\text { is available through a high technological app, which is so sophisticated that also other brands, such as UberIndia, } \\
\text { use it to promote and provide their products to the largest consumer base. }\end{array}$ \\
\hline & Economic Model & $\begin{array}{l}\text { Sellers do not have to pay a registration fee on the platform, but once their products are sold, they have to pay a } \\
\text { fee to Snapdeal that varies between } 7 \% \text { to } 20 \% \text { of products' value. Snapdeal also provides sellers free inventory } \\
\text { storage and helps them to get in touch with professional and experts for their various requirements, such as } \\
\text { onboarding, cataloguing, photography, and business consulting. Snapdeal revenue streams are made additionally } \\
\text { by the keywords advertising tools, which suggest to sellers the best-selling option for displaying their products in } \\
\text { a specific field. }\end{array}$ \\
\hline \multirow{3}{*}{ Stemcentrx } & Value Network & $\begin{array}{l}\text { The company collaborates with Pfizer for developing therapies for solid tumors. Labs are equipped with high tech } \\
\text { technologies and patents which represent the key resources of the company. The R\&D activity, due to the nature } \\
\text { of the service offered that requires constant update, represents instead the key activity of Stemcentrx. }\end{array}$ \\
\hline & $\begin{array}{l}\text { Customer Value } \\
\text { Proposition \& Interface }\end{array}$ & $\begin{array}{l}\text { The mission of the company is to develop therapies that cure and significantly improve survival for cancer patients. } \\
\text { The culture of Stemcentrx is mainly represented in a statement reported in the official website of the company, } \\
\text { which is: "We have a driven, ambitious, focused, hardworking, apolitical, fun and collaborative culture that is } \\
\text { more typical of Silicon Valley start-ups than large pharmaceutical companies". The company is pioneering new } \\
\text { approaches to eliminate cancer steam cells with initiate and perpetuate tumors. Actually, Stemcentrx has five } \\
\text { investigational drugs in human clinical trials, and is experimenting scientific research in some focused field of } \\
\text { cancer such as breast cancer, ovarian and peritoneal cancer. It also provides clinical trials and diagnostic tests that } \\
\text { can be used to identify those patients most likely to benefit from those drugs. Due to the nature of the business, } \\
\text { clients may be individual patients who are affected by these kinds of pathologies. Furthermore, hospitals, research } \\
\text { centers and clinical institutions can benefit from the knowledge developed during the experiments and implement } \\
\text { this approach in the treatment of their patients as well. The customer relationship is customized, and this mainly } \\
\text { depends on the nature of the problem and on personal issues of the patent. }\end{array}$ \\
\hline & Economic Model & $\begin{array}{l}\text { The revenue streams of the company partially come from the royalties payed by third parties for the usage of the } \\
\text { technology and the knowledge developed by Stemcentrx. }\end{array}$ \\
\hline Magic Leap & Value Network & $\begin{array}{l}\text { The company collaborates with Weta Workshop with the aim to bring the digital world beyond smartphones and } \\
\text { movies, and, simultaneously, with Nascent to develop novel human computing interface and software for mixed } \\
\text { reality and other applications. Furthermore, Magic Leap established a partnership with Onshape, which works in } \\
\text { web browser with a new operating system, and additionally with the giant Alibaba. The partnerships with Onshape } \\
\text { lets teams of designers to collaborate using a web browser, phone, or tablet computer on Windows, Mac, Linux, } \\
\text { or Chrome operating systems. The company bases its value on qualified employees. Those people are helped by } \\
\text { the company to find an innovative way of thinking the relationship between people and technology. For this reason, } \\
\text { one of the key activities of the company relates to the recruiting of new developers in order to discover new fresh } \\
\text { ideas or "to transform the world forever". On the other side, the patents through which the company protects its } \\
\text { knowledge and technology represent its key resources. }\end{array}$ \\
\hline
\end{tabular}




\begin{tabular}{|c|c|c|}
\hline & $\begin{array}{l}\text { Customer Value } \\
\text { Proposition \& Interface }\end{array}$ & $\begin{array}{l}\text { The mission of the company is highly focused on innovation and creativity, indeed, as stated in the website: "What } \\
\text { we found was when you give the brain and the body what they want; suddenly the shackles are off, the rectangular } \\
\text { boxes are tossed, and something magical happens... experiences like no one you have never seen". The } \\
\text { technology, which allows virtual 3D images to interact with real objects, is used for many diversified purposes, } \\
\text { such as work, entertainments and online shopping. Since the technology can be applied into different fields, the } \\
\text { intent of Magic Leap is to follow the customers' requests to give them a customized offer according to their } \\
\text { specific needs. An additional service available in the internet website is the blog where users can ask and comment } \\
\text { their feelings and ideas, and share posts in socials such as Facebook, Twitter, Google+, and LinkedIn. }\end{array}$ \\
\hline & Economic Model & $\begin{array}{l}\text { The company does not only earn money from the revenues related to the enrichment of contents requested by } \\
\text { customers, but also from the royalties paying by third parties for its patents. The biggest cost that the company has } \\
\text { to sustain is related to R\&D investments for further developments in augmented reality field. }\end{array}$ \\
\hline \multirow{3}{*}{ Zenefits } & Value Network & $\begin{array}{l}\text { Zenefits collaborates with Xero, an accounting software, to manage invoicing, bank reconciliation, and } \\
\text { bookkeeping. Other important relationships Zenefits established are those with Intuit, Paychex and Gusto. These } \\
\text { partnerships were established to manage HR payment system in a synchronized way for many companies. In } \\
\text { addition, the company started a collaboration with top applicant tracking systems such as Jazz, Greenhouse and } \\
\text { Lever, to let their customers to access Zenefits platform directly from their apps. The key resource of the company } \\
\text { is the platform that allows businesses to manage multiple human resources services from a single cloud base } \\
\text { dashboard. On the other hand, the key activity of the company consists in managing all the employees' data from } \\
\text { the different companies. }\end{array}$ \\
\hline & $\begin{array}{l}\text { Customer Value } \\
\text { Proposition \& Interface }\end{array}$ & $\begin{array}{l}\text { Clients can join Zenefits for two main reasons: (i) if a client is a small business advisor, this can join Zenefits to } \\
\text { manage all its clients' HR needs all in one place; or (ii) if the client is a product/service developer, this can join } \\
\text { the company to complements its product or service with those of Zenefits itself. Through the implementation of } \\
\text { Zenefits platform, companies can reduce their HR paperwork of about } 90 \% \text {. The total number of users refers to } \\
10.000 \text { companies, of which thousand are small businesses. Some of the company's clients are displayed in a } \\
\text { transparent way inside the website. These are, for example, Passport, Urbana, PinPress, TotalAcce, and Colorado } \\
\text { Outword Bound School. The value proposition of the company is dedicated exclusively to businesses of every } \\
\text { size, which want to find a way to simplify all the administrative works related to the HR management. In particular, } \\
\text { the value proposition shown in the website consists in a small range of services, which are payroll, benefits, time, } \\
\text { talent, compliance, and management. This mainly depends on the nature of the service, which is addressed } \\
\text { specifically to a given field, i.e. the HR one. For instance, the payroll service gives total visibility both to } \\
\text { companies and to their employees who can easily see what is changing in their wages, working days and absence } \\
\text { reasons. Nevertheless, the customer relationship is specific for each client, thus ensuring a particular customization } \\
\text { of the services offered by the company to its clients. In addition, the company allow clients to keep the already } \\
\text { implemented payroll solution and synchronize that with the rest of Zenefits services for free. }\end{array}$ \\
\hline & Economic Model & $\begin{array}{l}\text { Prices are different according to the specific service offered. For example, the payroll service is free until the end } \\
\text { of } 2016 \text { (after this date it will have a cost of } \$ 25 / \text { month plus } \$ 4 / \text { employee per month). Moreover, there are } \\
\text { customized offers for small businesses, which have allowed the company to earn } 100 \text { million } \$ \text { in revenues in } \\
2015 \text {. }\end{array}$ \\
\hline \multirow[t]{3}{*}{ Cloudera } & Value Network & $\begin{array}{l}\text { Cloudera has a robust partners' ecosystem, which allows customers to leverage investments and expertise today } \\
\text { while building the data platform of tomorrow. There are different types of partners who can be cluster in seven } \\
\text { categories: (i) Cloudera Reseller (for instance, Cisco, the worldwide leader in networking, is a partner of Cloudera } \\
\text { that belongs to this category, with the aim to transform of how people connect, communicate and collaborate), (ii) } \\
\text { Training delivery partners (i.e. Big Data Era Training Centre, which is a training institution specializing in big } \\
\text { data technologies and in the cultivation of talents in China), (iii) training reseller (i.e. Global Knowledge that is } \\
\text { the world leader in IT and business skill training with more than } 1200 \text { courses), (iv) hardware vendor (i.e. Dell), } \\
\text { (v) manage service providers (i.e. Hujitsu), (vi) software vendor (i.e. Anaconda, which empowers the entire data } \\
\text { science team), and (vii) system integrators (such as. Accenture). The total number of partners considering the } \\
\text { entire network ecosystem is around } 150+\text {. The key resources of the company are represented by (a) the Cloudera } \\
\text { community that allow to collaborate with peers, (b) industry experts and (c) Cloudera University where customers } \\
\text { receive expert Hadhoop training (Hadhoop is an open source software framework for distributed storage and } \\
\text { processing of very large datasets). The key activity of the Company consists in the supporting of customers not } \\
\text { only during the purchasing process, but also in the post purchasing phase, to exploit all the functionality of its } \\
\text { services. }\end{array}$ \\
\hline & $\begin{array}{l}\text { Customer Value } \\
\text { Proposition \& Interface }\end{array}$ & $\begin{array}{l}\text { The total number of users is about 525, divided between (i) business users that use the platform for data } \\
\text { management and analytics, (ii) developers that use the platform to build big data applications and IT professionals } \\
\text { allowing them to create a data management strategy. Moreover, Cloudera offers highest performance and lowest } \\
\text { costs platform for using data; this drives better business outcomes. However, the company tries to conduct three } \\
\text { main activities: (a) integrate and process more data in a faster way, (b) provide superior SQL and BI analytics, and } \\
\text { (c) provide real time, smart data application to monitor and personalize data analysis. The customer relationship } \\
\text { of the company is customized mainly because the company manage very different and personalized data, and } \\
\text { offers additionally specific training and support services for each of its customers }\end{array}$ \\
\hline & Economic Model & $\begin{array}{l}\text { The customer can download a free enterprise trial of Cloudera or try it in cloud for } 60 \text { days (after this period the } \\
\text { service has to be paid by users in accordance with dedicated contracts). }\end{array}$ \\
\hline \multirow[b]{2}{*}{$\begin{array}{c}\text { SoFi } \\
\text { (Social Finance) }\end{array}$} & Value Network & $\begin{array}{l}\text { The American Academy of Pediatric Dentistry announced its partnership with SoFi to help students repaying the } \\
\text { burden of loan. This loan covers the oral health expenses. Another partner is USI affinity that is an insurance } \\
\text { provider. Through this partnership, the two companies offer to Pennsylvania Bar Association (PBA) members the } \\
\text { opportunity to refinance their private and federal students' loan into a single loan with a lower rate and lower } \\
\text { monthly payment. In addition, the partnership with Businessolver, a leading SaaS-based benefits administration } \\
\text { technology provider, ensures students' loan refinancing and assistance programs such a as part of an employee's } \\
\text { total benefit package. The key activity of the company consists in managing payments and interests. The key } \\
\text { resource is the brand reputation due to the nature of the service offered. }\end{array}$ \\
\hline & $\begin{array}{l}\text { Customer Value } \\
\text { Proposition \& Interface }\end{array}$ & $\begin{array}{l}\text { The vision of the company is to offer better rates, zero fees, unprecedented services and awesome benefits; the } \\
\text { goal of SoFi is to help each of its members (investors and students) achieving their own financial goals. SoFi } \\
\text { originally utilized an alumni-funded lending model that connected students and recent graduates with alumni and } \\
\text { institutional investors via school specific student loan funds. Investors received a financial return and borrowers } \\
\text { received rates lower than the federal government offered. The company sought to minimize defaults by focusing } \\
\text { on low-risk students and graduates. The company also assists companies to allow them to have the best financial } \\
\text { success. The total number of user is about } 3 \text { billion. The company provides } \$ 8 \text { billion of loans and } 125,000 \\
\text { members compose the community. An additional category of services is represented by the customer service, } \\
\text { through which everyday specialists in the most reliable way give advices about the use of customers' money, as } \\
\text { well as the community events, through which the company offers happy hour to let customers meet each other. } \\
\text { The customer value proposition mostly is focused, and this mainly depends by the fact that only one service is } \\
\text { provided. Nevertheless, the customer relationship is customized according to the clients' money availability and } \\
\text { their risk predisposition, i.e. the version with which the service is provided varies between high risk or lower } \\
\text { profiles, short term or long term and repayments intervals. SoFi creates value in two primary ways. First, and very } \\
\text { simply, SoFi makes the experience of refinancing students' debt in a very user-friendly experience. The process } \\
\text { of obtaining education loans is rather long and complex, whether a student is borrowing from the government or }\end{array}$ \\
\hline
\end{tabular}




\begin{tabular}{|c|c|c|}
\hline & & $\begin{array}{l}\text { a private source. SoFi has made the application process completely electronic and more straightforward and offers } \\
\text { credit decisions in a shorter amount of time. }\end{array}$ \\
\hline & Economic Model & $\begin{array}{l}\text { SoFi does not charge an application or origination fee and makes money predominantly from the monthly } \\
\text { repayments of students at the designated rate they were charged. Because SoFi is a peer-to-peer lender, the } \\
\text { company also has a small portion of revenue coming from fees charged to lenders on its platform. However, the } \\
\text { majority of revenues comes from students' borrowers. }\end{array}$ \\
\hline \multirow{3}{*}{ Slack } & Value Network & $\begin{array}{l}\text { Slack is announcing a dozen launch partners for the button including Box, news app Nuzzel, and design } \\
\text { prototyping tool InVision. Other relevant partnerships are those with (i) Screenhero, which allows integrating } \\
\text { voice video screen features into slack; (ii) Groove, both in term of users engagement and new users acquisitions; } \\
\text { (iii) Unitefour in order to integrate in one tool SMS, Facebook, Yammer and documents review functionality that } \\
\text { enables system collaboration; (iv) Mautic, which provides free and open source marketing automation software } \\
\text { available to everyone; and (v) Skype in order to allow the different team members of Slack to start a call on Skype } \\
\text { directly, without creating a new account. The company is also planning to do partnerships with Lyft, Foursquare } \\
\text { and a couple of other services that will let customers request a car ride on Slack platform. The key activity of the } \\
\text { company is to implement a security system in messaging conversation. The key resources of the company are } \\
\text { related to the company's culture and the strong brand image, which are explained by reliability and trust, reinforced } \\
\text { by the usage of Slack's services by NASA. }\end{array}$ \\
\hline & $\begin{array}{l}\text { Customer Value } \\
\text { Proposition \& Interface }\end{array}$ & $\begin{array}{l}\text { Slack is a team communication application that provides services such as real time messaging and archiving } \\
\text { conversations of teams. The idea of the company is to make users' life simpler, more pleasant and more productive. } \\
\text { Single users who need an efficient way for the communication or secure and professional tools for storing some } \\
\text { relevant data characterize the customer segment. A specific section is characterized by enterprises, which could } \\
\text { assure more security. The customer relationship is mostly personalized because each team can customize its } \\
\text { services. The total number of users is about } 1.7 \text { million, and all of them can be connected simultaneously. The } \\
\text { value proposition of the company is quite focus and there is not a wide choice of services offered. In particular, } \\
\text { the company offers two versions of service, as pointed out in the economic model: standard and plus. }\end{array}$ \\
\hline & Economic Model & $\begin{array}{l}\text { The economic model is freemium. The standard version is available for free and additional services are paid to } \\
\text { have more space. The Slack plus costs } \$ 15 / \text { month, whereas the Slack standard is around } \$ 6.67 / \text { month. As far as } \\
\text { enterprises solutions are concerned, the payment relates only for the monthly use; there is not any fixed payment } \\
\text { for each user, but it depends based on what is used ( } \$ 45-47 / \text { month). }\end{array}$ \\
\hline \multirow{3}{*}{ Garena Online } & Value Network & $\begin{array}{l}\text { The company started to collaborate with MP \& Silva, a media rights company that owns, manages and distributes } \\
\text { sports media rights, in order to maximize the commercial opportunities in Asia. Furthermore, the partnership } \\
\text { between Garena and Riot Games ensures bringing League of Legends to Southeast Asia. Thanks to this } \\
\text { partnership, the company is able to produce and display the online game Path of Exile in Southern Asia. Moreover, } \\
\text { Garena established a partnership with Cybersource in order to increase the security of the payment and optimize } \\
\text { business operations. The key resource of the company is the users' network: the bigger it is, the better the game } \\
\text { experience. On the other side, the key activities mainly are based on the payment system management through } \\
\text { "the shells online currency". }\end{array}$ \\
\hline & $\begin{array}{c}\text { Customer Value } \\
\text { Proposition \& Interface }\end{array}$ & $\begin{array}{l}\text { The company is a leading platform provider for online and mobile entertainment and communication across } \\
\text { different countries. It connects } 17 \text { million of pc users and } 14 \text { million of mobile users. The first product launched } \\
\text { by the company is Garena+, which is an online game and social platform for people that allow them to meet each } \\
\text { other, chat and play games. The value proposition of the company is mainly diversified in the following services: } \\
\text { (i) TalkTalk, which is a highly engaging real time voice and video communication platform; (ii) BeeTalk, which } \\
\text { is a mobile app that helps people creating new relationships and joining new communities based on location and } \\
\text { interests; and (iii) Airpay, which is one of the South-east Asia's fastest growing payment networks and it is crucial } \\
\text { in order to provide accessible financial services also in emerging countries. The customer segment is divided } \\
\text { between (a) users who can virtually meet each other, play on the platform and chat; and (b) games developers who } \\
\text { can use the platform to display their products to have the largest customer base and gain traffic. The customer } \\
\text { relationship is mainly customized; indeed, gamers can create their own unique identity by personalizing their } \\
\text { avatar or changing their names. They are also able to form groups or clans, and chat with multiple gamers } \\
\text { simultaneously through public or private channels of Garenat. }\end{array}$ \\
\hline & Economic Model & $\begin{array}{l}\text { The revenue streams of the company come from the payment of customers for in-game additional services and } \\
\text { functionalities during the game experience. The system works thanks to "shells" that customers can buy in order } \\
\text { to have access to different purchasing formats (package of } 250,500,1.000,2.000,3.000 \text { shells). Garena Shells is } \\
\text { the online currency of Garena gaming platform and Garena operated games. Garena players can use their Garena } \\
\text { Shells to purchase many rewarding products and services, as well as in-game items. }\end{array}$ \\
\hline \multirow{3}{*}{ Credit Karma } & Value Network & $\begin{array}{l}\text { The company collaborates with Progrexion, which is a technology enabled consumer service business that leads } \\
\text { the way in credit repair; and with Prosper, which is a peer-to-peer landing marketplace. Credit Karma also started } \\
\text { to collaborate with TransUnion and VantageScore to offer free credit scores and reports; Credit Karma additionally } \\
\text { teams up with Intuit financial services in order to bring free credit scores to financial institutions. Finally, the } \\
\text { company established a partnership with FindSpark, which is a community dedicated to setting up young } \\
\text { professionals for career success. The key activity of the company consists in monitoring clients' feedbacks on the } \\
\text { online community page. While, the key resource relies in the blog page, available through the website, that display } \\
\text { contents and financial trends. }\end{array}$ \\
\hline & $\begin{array}{c}\text { Customer Value } \\
\text { Proposition \& Interface }\end{array}$ & $\begin{array}{l}\text { Credit Karma provides to more than } 11 \text { million members among which there are private investors. By tracking } \\
\text { and monitoring their credit and finances all in one place, the company allows clients to have transparent visibility } \\
\text { on their deposit. Credit Karma's goal is to help its members exploiting the most of their credit by offering insightful } \\
\text { saving recommendations based on unique data comparisons. The company also provides financial education and } \\
\text { access to free tools, such as the free credit report card and credit card statistics, which empower consumers to take } \\
\text { charge of their financial health. The business model of the company is characterized by three key characteristics: } \\
\text { (i) getting scores and reports with weekly updates, (ii) receiving recommendations that could help customers to } \\
\text { save money, and (iii) getting paid by the back or the lender. As stated in the website, "our business model works } \\
\text { because everyone can benefit, everyone wins". On one side, users can benefit from the company recommendations, } \\
\text { on the other one, financial partners can share the mission of Credit Karma. Consumers save money and banks turn } \\
\text { away fewer consumers. The customer relationship is customized according to the specific consumer financial } \\
\text { profile and money availability. Furthermore, the company offers a wide range of diversified financial tool. For } \\
\text { instance, credit score simulator, which can help answering to some of credit "what-ifs". }\end{array}$ \\
\hline & Economic Model & $\begin{array}{l}\text { The company earns money by banker or lenders, whereas the service for customers is free. However, after the } \\
\text { lending, users need to pay every month the money borrowed with the respective interest rate, which will increase } \\
\text { of } 33 \% \text { if the payment is done late (this also requires an additional late fee which ranges between } \$ 25 \text { to } \$ 35 \text { ). }\end{array}$ \\
\hline Tanium & Value Network & $\begin{array}{l}\text { As stated in the website, Tanium ecosystem is characterized by experienced partners who help enterprises around } \\
\text { the world to solve the most difficult security and IT challenges. The total number of partners in this ecosystem is } \\
\text { around } 28 \text {. There are two main groups of partners: technology and service partners. Within the first group we find } \\
\text { industry leading technology, such as Paloalto networks, PWC, and Splunk, whereas to the second one belong } \\
\text { security service providers, such as value added resellers that provide Tanium's market leading endpoints security, } \\
\text { and IT operations manager who help their customers to reduce the window of security risk, such as Hic, Ipss, and } \\
\text { Proficio. The key activity of the company consists in scanning customers' data in order to guarantee high security }\end{array}$ \\
\hline
\end{tabular}




\begin{tabular}{|c|c|c|}
\hline & & $\begin{array}{l}\text { standards. The key resource relies on the technology, which is behind the business model of Tanium that consists } \\
\text { in decentralizing the communication instead of reporting all the information to a central hub. }\end{array}$ \\
\hline & $\begin{array}{l}\text { Customer Value } \\
\text { Proposition \& Interface }\end{array}$ & $\begin{array}{l}\text { The vision of the company is "to be the platform that every enterprise on the planet will use to communicate every } \\
\text { IT assets they own in seconds". Tanium's customers are market leaders across variety of industries: } 8 \text { of the top } \\
10 \text { banks; } 4 \text { of the Fortune 10; number one companies across different industries. Some examples of the most } \\
\text { famous clients are Amazon, eBay and Zurich insurance group. Tanium offers a powerful and completely novel } \\
\text { way to scan and control the security of thousands of devices and this is in use by Visa, Amazon, Best Buy, the } \\
\text { U.S. Department of Defense and Nasdaq. Desktops, laptops, servers, cash registers and even heart-rate monitors } \\
\text { - each one a potential entry point for hackers - can be made accessible to network administrators in seconds } \\
\text { through Tanium. Due to the nature of the service, the customer relationship is standardized. Moreover, the service } \\
\text { offered is not diversified. }\end{array}$ \\
\hline & Economic Model & $\begin{array}{l}\text { The model of revenues is made by the subscription fee. In addition, there is the possibility to pay through rates by } \\
\text { leaving an initial down payment. }\end{array}$ \\
\hline \multirow{3}{*}{$\begin{array}{l}\text { Global Fashion } \\
\text { Group }\end{array}$} & Value Network & $\begin{array}{l}\text { The main partnerships the company established are those with fashion brands; Global Fashion Group collaborates } \\
\text { with } 3 \text { thousand regional and international fashion brands. Some relevant examples of collaborations are those } \\
\text { with United Colours of Benetton, Puma, PALOMINO, and INCITY. The key activities of the company mainly } \\
\text { relate to the control of the entire value chain, i.e. the logistics, stock management, order fulfilment, delivery, } \\
\text { payment, customer care, marketing and photography. The key resources, on which the company leverage, are the } \\
\text { talent and recruiting teams, the capital market teams and executives. The recruiting teams work with portfolio } \\
\text { companies to identify and recruit senior executives with a lot of expertise and board members, as well as advice } \\
\text { on the best practices in talent development. Capital markets teams help portfolio companies to structure the capital } \\
\text { market transaction and support grow initiatives providing access to the best executions pricing and structuring } \\
\text { available. Finally, through executives the company can assist companies in an ongoing capacity through board or } \\
\text { leadership roles. The key activity of the company consists in managing the logistic network for the distribution of } \\
\text { its products. }\end{array}$ \\
\hline & $\begin{array}{c}\text { Customer Value } \\
\text { Proposition \& Interface }\end{array}$ & $\begin{array}{l}\text { The mission of the company is to build a brand portfolio, which comprise international, local and private labels in } \\
\text { order to offer to the customers a wide assortment of products and brands; for this reason, the offer of the company } \\
\text { is much diversified. In this way, the company can offer to the customers the best product assortment and the best } \\
\text { shopping experience in emerging markets. For instance, (i) international brands are Aldo, Armani Jeans, and } \\
\text { DKNY; (ii) regional are AND and RIO; (iii) private labels are ATMOS\&HERE and ELLA. The company operates } \\
\text { with six branded platforms in } 27 \text { countries and employs over } 10.000 \text { people, working closely with partners. The } \\
\text { company has around } 5 \text { million of active subscribers; it received more than } 8.4 \text { million of orders in the first half of } \\
2014 \text { and generated } € 4.36 \text { million of gross merchandize volume. Because customers cannot personalize products } \\
\text { available on the website, but just buy the ones that are displayed, we cannot assume the customer relationship of } \\
\text { the company as customized. The value proposition is addressed to users who can find the right product on the } \\
\text { platform by choosing between many different brands, and retailers who gain visibility on their products and reach } \\
\text { a wider customer base. The company continuously explores adjacent category of fashion and personal care } \\
\text { products. }\end{array}$ \\
\hline & Economic Model & The main costs relate to the activities of controlling the value chain, from logistics to customer care. \\
\hline \multirow{3}{*}{ UCar } & Value Network & $\begin{array}{l}\text { The company started to collaborate with eDaijia in } 2015 \text {, which is the largest mobile platform for consumers to } \\
\text { find temporary drivers. Furthermore, the service is available in different airports and airlines companies. For } \\
\text { instance, on the website of some airlines companies it is possible to book both planes and cars. The key resource } \\
\text { on which the company relies is the logistic network of drivers, which allow spreading out the service, whereas the } \\
\text { company activities relate to the management of customers' payments. }\end{array}$ \\
\hline & $\begin{array}{c}\text { Customer Value } \\
\text { Proposition \& Interface }\end{array}$ & $\begin{array}{l}\text { The company provides car rental services in China. The interaction with customers is done through a mobile app. } \\
\text { The service is provided through licensed drivers and taxi companies; the intent of the company is to exclude private } \\
\text { vehicles on their platform due to security concerns. The service is highly customized and focused on customers' } \\
\text { satisfaction. For instance, in March } 2016 \text {, UCar launched a special service for pregnant women. They can use car } \\
\text { with strict standards, both for the vehicle (the temperature inside the car has to be } 22 \text { degrees) and the driver (the } \\
\text { speed has not to exceed } 60 \mathrm{~km} / \mathrm{h} \text { ). Accordingly, the CEO of the company said: "Pregnant women are a special } \\
\text { group, when they go out, their safety should be guarantee. That's why UCar is realizing this service." UCar covers } \\
\text { approximately } 60 \text { cities in China, but it is also available in others European countries. The value proposition of } \\
\text { the company is quite diversified; indeed, UCar offers comprehensive care hire services including short-term rental, } \\
\text { long-term rental and financial leasing, as well as assorted value-added services such as roadside assistance and } \\
\text { one-way rentals. The company has around } 466.520 \text { of active users. }\end{array}$ \\
\hline & Economic Model & $\begin{array}{l}\text { The car rental service allows users to make a car reservation through a credit card deposit in advanced. Then, the } \\
\text { service is paid through a rental fee, which varies according to the rental period. }\end{array}$ \\
\hline \multirow[t]{3}{*}{ Delivery Hero } & Value Network & $\begin{array}{l}\text { The company operates in many different countries, and it established specific partnerships in each of them. For } \\
\text { instance, Delivery Hero collaborates with Hungry House (a big player in the UK market that allows users to search } \\
\text { for restaurants and browse local takeaway menus before placing an order online) to make its market larger. In } \\
\text { Germany, the company established an exclusive partnership with popular and regional chains such as Joey's Pizza } \\
\text { and Smiley's Pizza. Furthermore, with Foodik, a company that distributes food to a network of human services } \\
\text { agencies. Accordingly, the Co-CEO of Delivery Hero said: "We are excited to merge with Foodik. The Foodik } \\
\text { team has successfully proven how to scale business sustainably in Russia. We are looking forward to the combined } \\
\text { business that will continue to be run by the Foodik team. This partnership will provide better online food ordering } \\
\text { experience to customers in Russia". An additional partnership is that with Sherpa, to open up access to hundreds } \\
\text { of popular restaurants currently without delivery drivers. In addition, the company established a partnership with } \\
\text { Independent Food Network (IFN), to allow customers to get exclusive access to group buying power and IFN } \\
\text { promotion. Furthermore, the company acquired Foodora for a strategic purpose related to delivery logistic. The } \\
\text { key resource of the company consists in building restaurants network in order to provide customers a wide choice } \\
\text { of products. On the other hand, the key activity consists in displaying only those restaurants which are in the } \\
\text { nearby to ensure a high service level. }\end{array}$ \\
\hline & $\begin{array}{c}\text { Customer Value } \\
\text { Proposition \& Interface }\end{array}$ & $\begin{array}{l}\text { It is an online food ordering service, operating in } 33 \text { countries. It allows linking customers' demand, which wants } \\
\text { to find foods easily in a convenient way, as well as restaurants, which need to gain visibility on their offers. The } \\
\text { business is based on three core values: smart, fast, reliable. Smart because the customer has access quickly to } \\
\text { thousands of restaurants, by paying online and saving its favourite menu. Fast because the food always is delivered } \\
\text { hot and on time. Reliable because there are millions of customers' reviews and ratings (this allow to easily find } \\
\text { the best restaurant and the tastiest food in customers' area.) The value proposition is very diversified, and this } \\
\text { mainly depends by the fact that customers can choose the food and the range of time shipping in accordance with } \\
\text { their needs. Furthermore, there is the possibility to filter by cuisine and menus on the app. The company } \\
\text { collaborates with } 100.000 \text { restaurants. In } 2012 \text {, the company processed } 9.56 \text { million of food orders, with an orders' } \\
\text { rate that is increased of about } 169 \% \text { compared to the previous year. }\end{array}$ \\
\hline & Economic Model & $\begin{array}{l}\text { The company does not charge customers anything for the usage of the app but asks to their restaurants a small fee } \\
\text { of } 10 \% \text { for each order it processes. }\end{array}$ \\
\hline
\end{tabular}




\begin{tabular}{|c|c|c|}
\hline \multirow{3}{*}{$V A N C L$} & Value Network & $\begin{array}{l}\text { The company started to collaborate with Global Logistic Properties (GLP) in 2011, a market leader in modern } \\
\text { logistics facilities in China and Japan. The company puts effort in optimizing its supply chain and creating a } \\
\text { successful logistic network to lower costs and speed up delivery. Furthermore, another partnership was made with } \\
\text { Psy to develop Psy related products, as for example company's signature graphic T-shirts. Local partnerships } \\
\text { appear as a key strategy to build trust and create value. The company announced a country-website in Vietnam, } \\
\text { with the aim to develop its own inventory. Finally, VANCL established a partnership with the Chinese Suning, a } \\
\text { consumer electronics and home appliances retailer, in 2012. The key activity consists in monitoring the most recent } \\
\text { fashion trends in order to offer the best products that fit customers' taste. The key resources are the users and the } \\
\text { retailers, who allow the platform to work. The company implements the strategy to treat the customers as modes } \\
\text { by displaying their pictures wearing VANCL clothing. }\end{array}$ \\
\hline & $\begin{array}{l}\text { Customer Value } \\
\text { Proposition \& Interface }\end{array}$ & $\begin{array}{l}\text { The company provides men and women fashion apparel, shoes, jeans and accessorize at reasonable price. } \\
\text { Furthermore, the customer relationship of the company is very customized, if we consider that VANCL lets } \\
\text { customers try on clothes after the delivery, while the courier waits. Whether clothes do not satisfy customers' } \\
\text { expectations, they can be sent back immediately. The value proposition is moreover much diversified, because the } \\
\text { offer links in all its forms the supply of retailers with the demand of clients. The company has around } 10 \text { million } \\
\text { of registered users. In addition, it does not own physical stores or distributors, but sells directly to online } \\
\text { consumers. }\end{array}$ \\
\hline & Economic Model & $\begin{array}{l}\text { Chen, the CEO of the company, said that he has found a sustainable profitable model: VANCL will return to the } \\
\text { basic of branding and try to produce scale and profits by accelerating inventory turnover and raising brands } \\
\text { premiums, as opposed to focusing on online expansion. }\end{array}$ \\
\hline \multirow{3}{*}{ Fanatics } & Value Network & $\begin{array}{l}\text { The main partners allow the company to offer sports equipment from leagues, teams and players. In addition, the } \\
\text { company collaborates with AvantLink.com, a leader in affiliate technology, to offer a robust set of tools free of } \\
\text { charge and the best support in the business. Thanks to this partnership, Fanatics can control campaign information } \\
\text { and work in a more efficient way. In general, the main categories of partners refer to more than } 100 \text { colleges, NBA } \\
\text { basketball teams, and Football teams belonging to NFL, Hockey NHL, and Auto-Racing NASCAR. The key } \\
\text { resources of the company is the partners' network, which allows the company to provide a large number of } \\
\text { different items of different sports. While, the key activity consists in stocks management to avoid the out of stock. }\end{array}$ \\
\hline & $\begin{array}{l}\text { Customer Value } \\
\text { Proposition \& Interface }\end{array}$ & $\begin{array}{l}\text { Fanatics has a broad online assortment through which offers hundreds of thousands of officially licensed items via } \\
\text { its Fanatics and FansEdge brands, as well as a largest selection of sports items. The customer base of the company } \\
\text { is addressed to sportive fans who wants to buy some objects related to their favourite teams. The company has a } \\
\text { multichannel strategy and operates in more than } 300 \text { online and offline stores. The offer is much diversified and } \\
\text { mainly because the company offers different brands and different sport items. There are two types of websites: (i) } \\
\text { the "standard" website, in which the offer is not very customized, indeed users can buy standards apparel, and (ii) } \\
\text { the "non-standard" website, which gives the possibility to people to express their distinctive style through fun } \\
\text { sports items. In this last case, of course, the offer seems to be quite customized. }\end{array}$ \\
\hline & Economic Model & $\begin{array}{l}\text { The revenue streams of the company are related to the online purchasing of products, whereas the main costs are } \\
\text { related to the logistics delivery costs, management of the returns and partnerships relationships keeping. }\end{array}$ \\
\hline \multirow{3}{*}{ DocuSign } & Value Network & $\begin{array}{l}\text { The company established a partnership with Microsoft for documents such as Outlook and Word. Thanks to this } \\
\text { partnership, DocuSign has allowed to its e-Signature apps and digital transaction management functionalities to } \\
\text { be widely available to businesses and consumers. On the other hand, the collaboration with Salesforce allowed the } \\
\text { company to benefit of faster document turnaround times, increase of accuracy and more streamlined sales } \\
\text { processes. With Google and NetSuite, the company established a partnership to allow users to easily install } \\
\text { DocuSign. However, hundreds of companies (such as Accenture and IBM) are collaborating with DocuSign to } \\
\text { provide consulting services. One of the main key resources of the company is brand reputation linked to the strong } \\
\text { reliability of the way through which the service is offered. The key activity is mainly based on the post purchasing } \\
\text { activities to manage technical problems in the sharing of documents. }\end{array}$ \\
\hline & $\begin{array}{l}\text { Customer Value } \\
\text { Proposition \& Interface }\end{array}$ & $\begin{array}{l}\text { DocuSign helps organizations of different dimensions, industries and geography to go digital by empowering each } \\
\text { of them to transact anything anytime, anywhere, and on any device. The company offers additionally an internal } \\
\text { university to extract the maximum value from internal resources. Furthermore, by choosing DocuSign, customers } \\
\text { can have access to professional services teams, which can be considered such as partners involved in the } \\
\text { achievement of digital business processes. The total number of users is around } 85 \text { million in } 188 \text { countries, and } \\
\text { the service is available in } 43 \text { languages. The customer segment deals with school permissions to business contracts, } \\
\text { both for small and medium businesses. There are three main groups of customers: (i) Individuals, (ii) Professionals } \\
\text { and (iii) Businesses. The value proposition of the company is focused if we consider that the company offers only } \\
\text { one kind of service based on the electronic signature. However, customers have the possibility to know at every } \\
\text { stage of the signing process the status of their documents, as well as receiving notifications and automatic } \\
\text { reminders. }\end{array}$ \\
\hline & Economic Model & $\begin{array}{l}\text { The service is free for } 30 \text { days, and then the price changes according to the group in which customers belong. For } \\
\text { instance, individuals have to pay } 7.50 € / \text { month, Professionals } 16.50 € / \text { month and Business } 25 € / \text { month. }\end{array}$ \\
\hline \multirow{3}{*}{ Moderna } & Value Network & $\begin{array}{l}\text { Such as reported in the website of the company, Moderna is creating a new ecosystem of in-house teams and } \\
\text { partners to develop the broadest possible array of drugs imaginable. The strategic partnerships were mainly } \\
\text { established with four main categories of partners: (i) pharmaceutical companies, such as Alexicon, AstraZeneca, } \\
\text { and MERCK, (ii) government organizations, such as DARPA, (iii) foundations, such as the foundation of } \\
\text { Bill\&Melinda Gates, and (iv) research institutes, such as the Institut Pasteur or the Karolinska Institutet. For } \\
\text { instance, in 2014, Moderna announced an exclusive strategic agreement with Alexion, with the aim to develop } \\
\text { novel and breakthrough therapies for patients with severe and life-threating rare diseases. The key resources of the } \\
\text { company are the patents that protect the technology, while the key activities are those related to R\&D in order to } \\
\text { search the newest and the best technology, instruments and knowledge. }\end{array}$ \\
\hline & $\begin{array}{l}\text { Customer Value } \\
\text { Proposition \& Interface }\end{array}$ & $\begin{array}{l}\text { The vision of the company is to create and deliver new generation of transformative medicines for patients. } \\
\text { Products of Moderna cover a broad expanse of drug modalities, including vaccines (both for infectious diseases } \\
\text { and for personalized cancer vaccines), intracellular/transmembrane proteins, intratumoral expression, and secreted } \\
\text { antibodies and proteins. The technology works in different fields: rare diseases, oncology, personalized cancer } \\
\text { vaccines, infectious disease, new venture labs and cardiovascular. The customer relationship of the company is } \\
\text { customized depending on the specific application. }\end{array}$ \\
\hline & Economic Model & $\begin{array}{l}\text { Moderna has developed a broad intellectual property estate, including more than } 320 \text { patent applications that cover } \\
\text { novel nucleotide chemistries and drug compositions. These patents represent the main source of revenues for the } \\
\text { company. The company plans to develop and commercialize its innovative mRNA drugs through a combination } \\
\text { of additional strategic relationships. }\end{array}$ \\
\hline $\begin{array}{l}\text { Wish } \\
\text { (ContextLogic) }\end{array}$ & Value Network & $\begin{array}{l}\text { The company established a significant amount of partnership. For instance, with Chukoul, a full service logistic } \\
\text { solution for multinational e-commerce companies, the company provides express delivery, overseas warehousing, } \\
\text { order management and supply distribution. The partnership with } 17 \text { track.net instead aims at providing } \\
\text { international shipping services and tracking information. Furthermore, the company collaborates with (i) } \\
\text { Aftership, a shipment tracking platform for more than } 189 \text { carriers worldwide; (ii) Payoneer, which empowers } \\
\text { global commerce by connecting businesses, professional, countries and couriers with its innovative cross-border } \\
\text { payment platform; (iii) Shang TongDai, which simplifies the lengthy manual loan application process to one } \\
\text { which is } 100 \% \text { automated online; (iv) Bejing Huafuda Information Technology, which is the world's online e- } \\
\text { commerce based transaction insurance and financial services provider; (v) DianXiaomi, which is the free ERP of }\end{array}$ \\
\hline
\end{tabular}




\begin{tabular}{|c|c|c|}
\hline & & $\begin{array}{l}\text { cross-border e-commerce; and (vi) ShipStation, which helps in defining automation rules filters and profiles to } \\
\text { make the copy and paste. The key activity of the company is the management of the communication and } \\
\text { distribution channel, through the customers' feedbacks and the logistic network, which also represents the key } \\
\text { resource of the company. }\end{array}$ \\
\hline & $\begin{array}{l}\text { Customer Value } \\
\text { Proposition \& Interface }\end{array}$ & $\begin{array}{l}\text { The mission of the company is to give everyone the access to the most affordable, convenient and effective } \\
\text { shopping mall in the world. The value proposition is split between two main actors, who are final users and } \\
\text { merchants. The users through the social platform can discover, collect, and share products with their friends. On } \\
\text { the other hand, it helps merchants to reach relevant users, who can personalize their shopping experience and } \\
\text { easily find the products they want. The total number of registered users is around } 160 \text { million, while the number } \\
\text { of merchants is about } 100.000 \text {. Hyper Reloaded people who want to share their fashion taste to have a feedback } \\
\text { in their social network characterize the customer segment. The platform works through a mobile/internet app. } \\
\text { Whether the user is not registered, he cannot access to the products and information. Moreover, the platform offers } \\
\text { around } 40 \text { million items among different categories, and mainly for this reason, we can consider the offer of the } \\
\text { company as quite diversified. In addition, by leveraging on big data principles, technology, advertising and } \\
\text { research, the company can create relevant entertaining and personalized browsing experience for each consumer } \\
\text { on both iOS and Android. }\end{array}$ \\
\hline & Economic Model & $\begin{array}{l}\text { The economic model of the company works on a revenue sharing money: the company gets paid when merchants } \\
\text { sell, although they do not have to pay any fees if they do not sell. As far as users are concerned, the registration is } \\
\text { free and they only have to pay merchants for goods that they purchased. }\end{array}$ \\
\hline \multirow{3}{*}{ Ele.me } & Value Network & $\begin{array}{l}\text { The company established partnerships with Didi Kuaidi and with Rajax (a company that works in the information } \\
\text { technology field by using a platform able to deliver product in one hour), with the aim to serve its customers in } \\
\text { short time windows. The key resource of the company is the platform, which allows demand and supply to meet } \\
\text { between each other. The key activity relies on the monitoring of customers' taste and the addition of further offer } \\
\text { categories. }\end{array}$ \\
\hline & $\begin{array}{l}\text { Customer Value } \\
\text { Proposition \& Interface }\end{array}$ & $\begin{array}{l}\text { Ele.me serves over } 40 \text { million users in hundreds of cities, collaborating in the process with over } 300.000 \text { restaurants } \\
\text { around China. The value proposition of the company is addressed to users who want a meal and to restaurants, } \\
\text { which want to increase their customer base. Ele.me does not deliver food directly. Rather, the company satisfy } \\
\text { customer needs by outsourcing the delivery service and in order to not only deliver food on time, but also to ensure } \\
\text { its optimal temperature and taste through a customized customer relationship and diversified customer offer. The } \\
\text { channels through which the company reach customers are the website and the mobile app. Users do not need to } \\
\text { be registered to make a reservation. People who want to order a ready meal at a specific hour in order to save time } \\
\text { and people who are available to go directly to the restaurant without waiting for the order preparation compose } \\
\text { the customer segment. Furthermore, there is the possibility to get the order delivered by one of the company's } \\
\text { drivers partners. Customers can order food through the website and mobile app. }\end{array}$ \\
\hline & Economic Model & $\begin{array}{l}\text { Ele.me earns revenues by charging a fee from the restaurants on the orders placed through its platform. The } 98 \% \\
\text { of its turnover derives from its mobile app. }\end{array}$ \\
\hline \multirow{3}{*}{ HelloFresh } & Value Network & $\begin{array}{l}\text { The company established partnerships with local suppliers with the aim of offering to customers fresh, and high- } \\
\text { quality ingredients. Each week HelloFresh frequently started new collaborations with other brands to provide a } \\
\text { diversified offer. For example, the partnership with Birrittella's bakery, in New York, aims at providing } \\
\text { ingredients for pizza in customer's box, whereas that with Murray's Chicken wants to provide natural and healthy } \\
\text { chicken. Finally, another partnership was established with Jamie Oliver, a British celebrity chef, who creates } \\
\text { recipes for HelloFresh, and receives, by the company, donations for his Jamie Oliver Food Foundation. The key } \\
\text { activity of the company is the delivery management in order to provide a high service level in terms of time. On } \\
\text { the other hand, the key resource consists in the supply network, which provides customers the healthier and } \\
\text { wholesome ingredients. }\end{array}$ \\
\hline & $\begin{array}{l}\text { Customer Value } \\
\text { Proposition \& Interface }\end{array}$ & $\begin{array}{l}\text { The company addresses its value proposition to people who want to cook something in a healthy way. The system } \\
\text { is based on several steps. Initially, HelloFresh provides users a wide set of recipes allowing the user to choose the } \\
\text { one he or she prefers; accordingly, the company sends to users all the ingredients. Therefore, HelloFresh delivers } \\
\text { to customers all the ingredients and users can start to cook. There are different kind of boxes: (i) veggie, classical } \\
\text { (ii) and (iii) family boxes. The company operates in seven countries. A meal can be ready in maximum } 30 \text { minutes } \\
\text { and it is kept in environmental friendly packaging. The company uses word-of-mouth in an extremely smart way: } \\
\text { on one hand, providing to customers (and their friends) discounts if they start using the service and, on the other } \\
\text { hand, encouraging users to share their ready meals on social media. Users need to be registered to have access to } \\
\text { the service; they also have the possibility to share comments and advices with other users by using the blog section. }\end{array}$ \\
\hline & Economic Model & $\begin{array}{l}\text { Revenue streams of the company are based on the payment of the different boxes options. The price is different } \\
\text { based on the ingredients and size of the box. For example, the Veggie Box costs } \$ 9,08 / \text { meals, the Classic Box } \\
\text { costs } \$ 9,90 / \text { meals and the Family Box } \$ 8,75 / \text { meals. Moreover, the company benefits from the commission fee } \\
\text { paid by the partners to be displayed on the platform. The fee is calculated based on the sales amount. }\end{array}$ \\
\hline \multirow{3}{*}{ Bloom Energy } & Value Network & $\begin{array}{l}\text { The main partnerships of the company are those with (i) Exelon, to provide clean distributed power to commercial } \\
\text { customers, and (ii) banks, utilities and other institutional investors, to offer tailored financing options to customers. } \\
\text { Another significant collaboration Bloom Energy established is with Vapor Io, a company operating in IT } \\
\text { infrastructures. Furthermore, WGL and Bloom Energy collaborates into the Power Santa Clara County for a } 2.6 \\
\text { MW of Clean Energy. Other partners of the company are the Advanced Energy Design Guides (AEDG), which } \\
\text { represents a series of publications designed to provide recommendations for achieving energy savings and those } \\
\text { with Radnor, PA and Horizon Energy of Lancaster. The key resources of the company are the fuel cells devices } \\
\text { and the relative patents, whereas the key activity is the management of customers' relationship to keep them loyal } \\
\text { and satisfied. }\end{array}$ \\
\hline & $\begin{array}{l}\text { Customer Value } \\
\text { Proposition \& Interface }\end{array}$ & $\begin{array}{l}\text { Bloom Energy offers fuel cells capable of producing air and fuel from electricity generated by a solar panel. } \\
\text { Through fuel cell devices, the company is able to convert fuel into electricity with clean electro-chemical process } \\
\text { rather than dirty combustion. The fuel cells have the following characteristics: (a) low cost materials instead of } \\
\text { using precious metals like platinum; (b) high electrical efficiency fuel flexibility; (c) the system can use either } \\
\text { renewable or fossil fuels. Each Bloom Energy server provides } 200 \mathrm{KW} \text { of power, enough to meet the baseload of } \\
160 \text { average homes and office building. Bloom Energy helps customers to lower their energy costs, reduce their } \\
\text { carbon footprint, improve their energy security and highlight their commitment to a better future. The main clients } \\
\text { of the company operate into the industries of (i) retail and logistics, such as FedEx, Ikea, and Macy's; (ii) } \\
\text { technology, such as Apple, and Adobe; (iii) banking, real estate and financing, such as the Bank of America and } \\
\text { Morgan Stanley; (iv) manufacturing, such as Honda and Xilinx; (v) food and beverage, such as Kellogg's and } \\
\text { Coca Cola; (vi) data centres, such as Apple and eBay; (vii) biotechnology and healthcare, such as BD and Kaiser } \\
\text { Permanente; (viii) government and military, such as NASA and the Department of American Defence; (ix) } \\
\text { utilities, such as PG\&E, Washington and Gas; (x) no profit organizations and universities; and (xi) entertainment, } \\
\text { such as Dream Works. More than } 70 \text { multinational firms are registered in the website to use their products. The } \\
\text { service offered is not diversified, but highly customized. }\end{array}$ \\
\hline & Economic Model & The company makes money from the royalties paid from their patents. \\
\hline
\end{tabular}




\begin{tabular}{|c|c|c|}
\hline \multirow[t]{3}{*}{ Powa } & Value Network & $\begin{array}{l}\text { The Otto Group has announced a partnership with Powa to secure and enhance a strong position in the modern } \\
\text { retail market. This partnership aims at providing to the millions of customers of Otto Group a quick and simple } \\
\text { way to shop and engage with its brands online, in-store and on the go. Powa established a collaboration with } \\
\text { Danske Bank on mobile payments and with UnionPay to create ubiquitous new standard in mobile commerce for } \\
\text { China. Another partner is that with Teller to offer a revolutionary solution of mobile commerce. Moreover, the } \\
\text { company collaborates with Swiff to bring the next generation of mPOS (mobile point of sales) and with Asia } \\
\text { Pacific Distribution Deal. In addition, Moneris, one of the larger processor of credit and debit cards in the US did } \\
\text { a partnership with the company. Furthermore, the global partnership between Powa and IBM enables businesses } \\
\text { around the world to offer instant mobile commerce. Finally, the company started to collaborate with GoNet to } \\
\text { introduce advance tablet base POS in Latin America Colombian and Spanish retailer. The key resource of the } \\
\text { company is the technology, while the key activity consists in simplifying as much as possible the interface between } \\
\text { machines and final customer. }\end{array}$ \\
\hline & $\begin{array}{l}\text { Customer Value } \\
\text { Proposition \& Interface }\end{array}$ & $\begin{array}{l}\text { Powa is an international commerce specialist, which creates technologies to seamlessly integrate physical and } \\
\text { digital world. The Powa suite of commerce solution is made for a world where consumers hold the future in their } \\
\text { hand, for instance laptop, tablet and mobile. The offer of the company is divided in three main areas, which are: } \\
\text { (i) Powa Web, a SaaS cloud base commerce platform, (ii) Powa POS, a hardware and software platform which } \\
\text { customises the payment experience in store, (iii) Powa Tag, which transforms consumer shopping behaviour by } \\
\text { eliminating the wait between impulse and purchase online and offline; and (iv) MPowa, a credit card processing } \\
\text { dongle. On March } 2,2016 \text {, Sky News revealed that two of Powa's core businesses, i.e. PowaWeb and PowaTag, } \\
\text { have been sold. Under separate deals, PowaTag has been sold to a private consortium, whereas PowaWeb has } \\
\text { been sold in a buyout backed by Greenlight Digital. }\end{array}$ \\
\hline & Economic Model & $\begin{array}{l}\text { Powa earns revenues by charging the merchants a fee of } 40 \text { cents or } 10 \text { basis points per transaction, whichever is } \\
\text { higher. }\end{array}$ \\
\hline \multirow{3}{*}{$\begin{array}{l}\text { Oscar Health } \\
\text { Insurance }\end{array}$} & Value Network & $\begin{array}{l}\text { The company collaborates with Telemedicine Company TeleDoc to provide online visits to customers rather than } \\
\text { being physically present, and with Misfit to offer members free wearable fitness trackers along with } \$ 240 \text { Amazon } \\
\text { gift cards per year to users who download the app and use it to track walking. Moreover, Oscar collaborates with } \\
\text { QualCare, New Jersey's highly regarded managed care organization, to bring new options and healthcare } \\
\text { experiences to New Jersey residents. The key resource is the brand that ensures reputation and reliability, and the } \\
\text { key activity consists in building an appropriate doctors' network to provide the service. }\end{array}$ \\
\hline & $\begin{array}{c}\text { Customer Value } \\
\text { Proposition \& Interface }\end{array}$ & $\begin{array}{l}\text { Oscar is a health insurance company that uses technology, design and data to humanize healthcare and offers better } \\
\text { care at lower costs. Oscar is for everyone and for every moment } 24 / 7 \text {. The value proposition of the company is } \\
\text { addressed both to doctors and to customers. The availability of more doctors means more choices for insured, and } \\
\text { consequently, greater convenience. More insured means more potential customers for doctors. The customers } \\
\text { segment is composed by people who need an insurance health coverage and want to have access to this service } \\
\text { through a mobile device and app to access their data frequently and have a track of their health situation. The } \\
\text { number of customers was on September } 2015 \text { in New York and Ney Jersey areas around } 40 \text { million. Due to the } \\
\text { nature of the service, which aims at satisfying customers' needs and priorities, the customer relationship is highly } \\
\text { customized, and the customer offer is diversified. }\end{array}$ \\
\hline & Economic Model & $\begin{array}{l}\text { The revenue streams come from customer's payment. Although a patient could have some services for free (such } \\
\text { as talking to the doctors anytime, preventive care, or generic drugs), for everything else he or she need to pay. }\end{array}$ \\
\hline \multirow{3}{*}{ InMobi } & Value Network & $\begin{array}{l}\text { Independent ad network, InMobi has expanded its partnership with a location-data software provider, Factual, in } \\
\text { order to include the company's location-based audience data within private marketplace environments on the } \\
\text { InMobi Exchange. Partnerships are built depending on the specific areas. For example, as far as the developers } \\
\text { are concerned the main are those with MAG interactive, Lima Sky, Vasco Games, Fingersoft, 1Bottom, } \\
\text { PicCollage. Accordingly, the total number of partnerships are around } 15 \text {. The key resources of the company are } \\
\text { the customers' data, which also are the main source of revenues of the company. The key activities relate to the } \\
\text { monitoring of the customers online activities in order to suggest them the best offer. }\end{array}$ \\
\hline & $\begin{array}{c}\text { Customer Value } \\
\text { Proposition \& Interface }\end{array}$ & $\begin{array}{l}\text { The company creates a Miip-InMoby Discovery Platform to deliver customized user experience for customers' } \\
\text { app. InMobi enables consumers to discover amazing products through the mobile advertising. Through Miip, a } \\
\text { revolutionary discovery platform, developers, merchants \& brands can engage mobile consumers globally. InMobi } \\
\text { enables over } 100 \text { billion discovery sessions on mobile across a billion users every month. The total number of } \\
\text { users is about } 872 \text { in over } 200 \text { countries. Three main groups compose the customer segment: developers, retailers } \\
\text { and brands. Developers through Miip can grow their app business by providing a higher user experience; retailers } \\
\text { are helped discovering the clients and engage with them a conversation across the app; brands are helped } \\
\text { discovering customer emotions, areas of action and engagement. The customer relationship is customized in } \\
\text { accordance to the customers' necessities and field. }\end{array}$ \\
\hline & Economic Model & $\begin{array}{l}\text { InMobi has a different pricing option based on the kind of targets that customers choose. There are two approaches, } \\
\text { which based on Cost Per Click or Cost Per Install. }\end{array}$ \\
\hline \multirow[t]{3}{*}{ Mozido } & Value Network & $\begin{array}{l}\text { Mozido and Tata Consultancy Services (TCS) announced a strategic partnership in 2012, whit the aim to support } \\
\text { the global expansion of Mozido's unique mobile payment platform. The company also collaborates with } \\
\text { TabbedOut, to build the quickest and most secure way to pay at thousands of bars and restaurants and to improve } \\
\text { the experience of consumers through a mobile application. In addition, Saavn, India's leading music streaming } \\
\text { service, announced an agreement with Mozido. The partnership will leverage Mozido's mobile wallet and } \\
\text { engagement platform to streamline payments, rewards, financial services, and offers for Saavn's } 18 \text { million } \\
\text { listeners. Moreover, the company established partnerships with IdentityMind to expand secure mobile commerce } \\
\text { around the world, with Shoptology, which is a shopper engagement agency, focused on driving breakthrough } \\
\text { growth through shopper insights; and with SecureNet to offer enhanced payment options. The company } \\
\text { collaborates with MasterCard in order to integrate MasterCard payments and security products into Mozido's } \\
\text { global system. The key resource of the company lies in the cloud-based technology aligned with PCI security } \\
\text { compliant which is able to operate on any mobile platform making it the ideal solution for users. The key activities } \\
\text { of the company are marketing and advertising, while the key resource relies on the patents on which the technology } \\
\text { is based. }\end{array}$ \\
\hline & $\begin{array}{c}\text { Customer Value } \\
\text { Proposition \& Interface }\end{array}$ & $\begin{array}{l}\text { Mozido allows mobile applications and mobile wallets to function worldwide regardless of geography, currency } \\
\text { or language while offering localized solutions to the market. The company offers B2B services in three main } \\
\text { streams: (i) Pay through which branded mobile wallet can deliver all the services that need to manage money } \\
\text { through mobile devices; (ii) Reward, which gives customers the flexibility to create, customize, brand and to } \\
\text { maintain an engaging loyalty program; (iii) Engaged, which helps customers to maximize their lifetime value } \\
\text { through higher return and increased in monetization. Customers can be cluster into five main categories: financial } \\
\text { institutions, retail, Telecos, CPG, government. The value proposition is not very diversified, since the company } \\
\text { offers just three kinds of services, but the customer relationship is customized in accordance to customers' needs } \\
\text { and industry. The company has around } 6 \text { billion of mobile phone subscription worldwide. Two billion self-banked } \\
\text { consumer with mobile phone access. Mozido expected early adoption numbers of around } 50.000 \text { users by the end } \\
\text { of } 2014 \text {, with exponential growth following the adoption curve over the next few years. }\end{array}$ \\
\hline & Economic Model & $\begin{array}{l}\text { The technology developed by the company has been patented and allows the company to raise money from } \\
\text { royalties. However, this stream is additional to the payments of customers for the services provided. }\end{array}$ \\
\hline
\end{tabular}




\begin{tabular}{|c|c|c|}
\hline \multirow{3}{*}{ Houzz } & Value Network & $\begin{array}{l}\text { The company collaborates with AIA (American Institute of Architect) to develop innovative technology initiatives } \\
\text { that engage architects and increase public awareness and appreciation of how good design can enhance people } \\
\text { life. For similar reasons, the company started to collaborate with ASID (American Society of Interior Designers) } \\
\text { and NAHB (National Association of Home Builders). The key resource is represented by the partners' network, } \\
\text { while the key activity is related to the management of the community and customers' feedbacks. }\end{array}$ \\
\hline & $\begin{array}{l}\text { Customer Value } \\
\text { Proposition \& Interface }\end{array}$ & $\begin{array}{l}\text { The value proposition of the company consists in two key sides: (i) from one side, Homeowners connect with } \\
\text { architects and designers, find inspiration thanks to photos, comments, recommendations and discussions at the } \\
\text { right price and at the right moment choosing among a wide diversified assortment; (ii) on the other side } \\
\text { Professionals can share their ideas and projects and gain visibility. Users can find a customized offer thanks to } \\
\text { filters (such as budgets, dimension, position and specific features). Homeowners interested in remodelling the } \\
\text { spaces of their home (such as kitchen and bedrooms) compose the customer segment. Millions of homeowners } \\
\text { compose the total number of mobile/internet users. Furthermore, on the platform around } 250.000 \text { actors, among } \\
\text { which architects and designers, can gain visibility. }\end{array}$ \\
\hline & Economic Model & $\begin{array}{l}\text { There are two versions of the service: (i) the standard one that is free, and (ii) the pro one that has an annual } \\
\text { subscription. Furthermore, a commission received by the company from the sellers, which is around the } 15 \% \text { of } \\
\text { the transaction, composes the revenue streams. }\end{array}$ \\
\hline \multirow{3}{*}{ Adyen } & Value Network & $\begin{array}{l}\text { The company announced an expansion of its existing partnership with Uber powering payments for the ride hailing } \\
\text { company's users in Casablanca, Morocco. It has formed a new partnership with UATP, a global corporate travel } \\
\text { payment network. This newly created relationship allows airlines utilizing the Adyen payment solution to accept } \\
\text { UATP, the preferred form of payment by corporations globally, and expand their corporate market share. } \\
\text { Furthermore, the company established a partnership with Dropbox to provide international payments services } \\
\text { across } 12 \text { European countries. In partnership with Edgar, Dunn \& Company (EDC), a global strategy consulting } \\
\text { specialized in payments, the company has identified } 8 \text { best practices to increase online revenues. Finally, another } \\
\text { partnership has been realized with Zuora in order to enable merchants to support recurring billing and subscription } \\
\text { payments worldwide. The key resource of the company consists in the Adyen Technology, which is developed } \\
\text { and maintained in house. For this reason, the company has the control and the flexibility necessary to meet the } \\
\text { evolving demands of the most innovative businesses, as well as to release new features. The company } \\
\text { has collaborations with all major credit card companies as well as local payment processors in each country where } \\
\text { it operates. The key activities relate to R\&D in order to improve the technology. }\end{array}$ \\
\hline & $\begin{array}{l}\text { Customer Value } \\
\text { Proposition \& Interface }\end{array}$ & $\begin{array}{l}\text { Adyen is the leading technology provider powering payments for global commerce. It offers to costumers a wide } \\
\text { range of diversified services, but the customer relationship is not very customized. For instance, the Online } \\
\text { payment is a traditional online payment through which the company tries to facilitate almost all the forms of online } \\
\text { payments. Through the Mobile payment the company helps customers to have a great mobile experience. With } \\
\text { the Point of sales payments, the company offers a variety of internet base Pos solution for Europe and USA both } \\
\text { for enterprises and mid-market merchants. Finally, the Risk management services are useful for delivering a } \\
\text { sophisticated protection, which protects during the transaction process from fraud. In this respect, the vision of the } \\
\text { Adyen is to optimize the payment to increase revenues. Over } 4.500 \text { customers from all over the world, accepting } \\
\text { more than } 250 \text { different payments types, use the Adyen payment platform. The company has an impressive clients' } \\
\text { list. Among them are online giants such as Facebook, Airbnb, Netflix, Spotify, Uber and Groupon. Totally, more } \\
\text { than } 3.500 \text { separate merchants had signed on to use Adyen by the end of } 2014 \text {. The company reportedly earned } \\
\$ 180 \text { million in revenues in } 2014 \text { thanks to its large user base. }\end{array}$ \\
\hline & Economic Model & $\begin{array}{l}\text { The main revenue streams of the company come from the customers' payments, instead the cost structure is mainly } \\
\text { done by the implementation of the technology. }\end{array}$ \\
\hline \multirow{3}{*}{ DraftKings } & Value Network & $\begin{array}{l}\text { The company started to collaborate with the National Hockey League and with the National Football League, } \\
\text { Major League Baseball, major League Soccer, NASCAR and Ultimate Fighting Championship. } \\
\text { The key resource of the company is the customers' network; the more the customers are, the more the game is } \\
\text { interactive and involving. The key activity consists in improving the design of the graphic interface to make it } \\
\text { more realistic. }\end{array}$ \\
\hline & $\begin{array}{l}\text { Customer Value } \\
\text { Proposition \& Interface }\end{array}$ & $\begin{array}{l}\text { DraftKings provides a daily fantasy sport website where customers can play against their friends in a single day } \\
\text { online games for cash and prizes across different sports. Users can sign up for free and choose among different } \\
\text { daily links for fantasy football, baseball, basketball and other sports. Mainly for this reason, the value proposition } \\
\text { is quite diversified, although the customer relationships are not customized. Another key functionality in the } \\
\text { platform lies in the possibility to make bets between users. Then users can draft a line up and win cash. Users can } \\
\text { play anywhere because the service is available through desktop, tablet and mobile with apps for iOS and Android. } \\
\text { The slogan of the company is "For every sport fan, every day". The total number of users is around } 1 \text { million. }\end{array}$ \\
\hline & Economic Model & $\begin{array}{l}\text { To choose one of the game, customers have to pay an entry fee required to join, which is kept by the company. } \\
\text { Whether users want to find games they just have to enter a low fee, whereas the fee increase whether users want } \\
\text { to play. }\end{array}$ \\
\hline \multirow{3}{*}{ Trendy Group } & Value Network & $\begin{array}{l}\text { The company established a partnership with Miss Sixty in } 2011 \text { and with } 10 \text { Corso Como, a luxury lifestyle concept } \\
\text { store. Trendy Group collaborates additionally with SuperGroup Plc, which ensures to the company a significant } \\
\text { long-term growth in its market. In addition, L Capital Asia invested \$ } 200 \text { million to build a strategic partnership } \\
\text { with the Group. The key resource of the company is the network of sellers, while the key activity relies on the } \\
\text { logistic network. }\end{array}$ \\
\hline & $\begin{array}{l}\text { Customer Value } \\
\text { Proposition \& Interface }\end{array}$ & $\begin{array}{l}\text { The company runs more than } 2.000 \text { retail stores in China for } 8 \text { brands including European, and it use an omni- } \\
\text { channel strategy in its operations; the company sells products both online and in its stores. The value proposition } \\
\text { of the company is split between users who have a wide choice of differentiated brands and products, and fashion } \\
\text { retailers who can gain traffic and visibility, even if they are not based on the Chinese market. Customers do not } \\
\text { have a customized offer because they can choose among the only available brands and products offered. The } \\
\text { company intent is to make fashion and its craft more democratic, more accessible, closer to people, a new } \\
\text { interaction model with customers, designers and artists alike, and a new online/offline inter-relationship. }\end{array}$ \\
\hline & Economic Model & $\begin{array}{l}\text { The revenue streams come from the payments of the customers and from the shipping fee which vary in accordance } \\
\text { to the location of delivery. }\end{array}$ \\
\hline
\end{tabular}

